\title{
MAPEAMENTO DE QTLs PARA REAÇÃO À DOENÇA MANCHA DE Phaeosphaeria EM MILHO
}

\author{
JOSÉ UBIRAJARA VIEIRA MOREIRA
}

\begin{abstract}
Tese apresentada à Escola Superior de Agricultura "Luiz de Queiroz", Universidade de São Paulo, para a obtenção do título de Doutor em Agronomia, Área de Concentração: Genética e Melhoramento de Plantas.
\end{abstract}

P I R A C I C A B A

Estado de São Paulo - Brasil

Dezembro - 2004 


\section{MAPEAMENTO DE QTLs PARA REAÇÃO À DOENÇA MANCHA DE Phaeosphaeria EM MILHO}

\section{JOSÉ UBIRAJARA VIEIRA MOREIRA}

Engenheiro Agrônomo

Orientador: Prof. Dr. CLÁUDIO LOPES DE SOUZA JÚNIOR

Tese apresentada à Escola Superior de Agricultura "Luiz de Queiroz", Universidade de São Paulo, para a obtenção do título de Doutor em Agronomia, Área de Concentração: Genética e Melhoramento de Plantas.

P I R A C I C A B A

Estado de São Paulo - Brasil

Dezembro - 2004 
Dados Internacionais de Catalogação na Publicação (CIP) DIVISÃO DE BIBLIOTECA E DOCUMENTAÇÃO - ESALQ/USP

Moreira, José Ubirajara Vieira

Mapeamento de QTLs para reação à doença mancha de Phaeosphaeria em milho / José Ubirajara Vieira Moreira. - - Piracicaba, 2004.

$86 \mathrm{p}$.

Tese (Doutorado) - - Escola Superior de Agricultura Luiz de Queiroz, 2005. Bibliografia.

1. Mancha foliar 2. Mapeamento genético 3. Marcador molecular 4. Milho 5. Resistência genética vegetal I. Título

CDD 633.15

"Permitida a cópia total ou parcial deste documento, desde que citada a fonte - O autor" 


\section{DEDICATÓRIA}

Aos meus pais Cecília e Ubirajara, Ao meu irmão Flávio,

pelo amor, pela confiança, pela compreensão e pelo apoio. 


\section{AGRADECIMENTOS}

A Deus,

À Escola Superior de Agricultura "Luiz de Queiroz"-ESALQ/USP, particularmente ao Departamento de Genética, por possibilitar a realização deste trabalho;

Ao Conselho Nacional de Desenvolvimento Científico e Tecnológico - CNPq pela concessão da bolsa de estudo;

Ao Prof. Dr. Cláudio Lopes de Souza Júnior, pela orientação, pelos ensinamentos, pela confiança, pela paciência e pela amizade;

À Profa. Anete Pereira de Souza e a toda a equipe do laboratório CEBMEG da Unicamp, pela realização das análises laboratoriais;

Aos professores do Departamento de Genética, pelos ensinamentos transmitidos;

A todos os funcionários do Departamento de Genética pelo apoio, pela amizade e pela condução dos experimentos, em especial a Antônio Juscelino Desidério, Ariberto Soares e Márcio de Araújo;

Aos amigos do Laboratório do Prof. Cláudio: Dyeme Bento, Mateus Figueiredo, Tassiano Câmara, Geovani Alves, Milena Lima, Sidney Parentoni, Adelmo Silva, Aurélio Aguiar, Gustavo Môro, Nelson O. Filho, Tiago Romani;

Em especial aos amigos Luciana Carlini-Garcia e Augusto Garcia pela amizade, pela consideração de todos os momentos e pelos valiosos ensinamentos;

À Kátia Brunelli pelo apoio e pelo treinamento no início das avaliações experimentais;

Aos amigos de Piracicaba: Rodrigo Brogin, Rudimar Conte, Fernando Cárdenas, Francisco Farias, Vanderlei Santos, Frederico Matta, Fábia Botelho, Clideana Maia, Raimundo da Cunha, Eulália Hoogerheide, Adalgisa Torres, Ebert Flor, Glauce Rumin, 
Karina Martins, Carolina Morgante, Adriano Castro, Mateus Mondin, Karém Xavier, Éder de Oliveira, Paulo de Araújo, e aos demais colegas da pós-graduação em Genética da ESALQ;

A Renata de Oliveira pelo apoio e companherismo, e a toda sua família pelo convívio e pela amizade, em especial à D. Ana, ao Sr. Edson, Ricardo, à Rosângela, ao Ricardo Fornazier e aos sobrinhos Gabriela, Vinícius e Giovana;

Aos primos, tios e demais parentes que também me incentivaram.

Obrigado! 


\section{SUMÁRIO}

Página

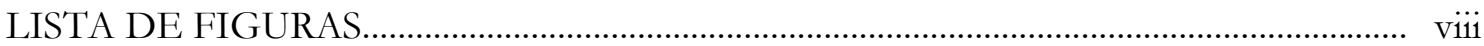

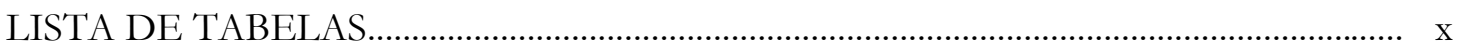

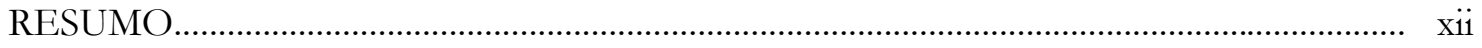

SUMMARY .................................................................................................................... xiv

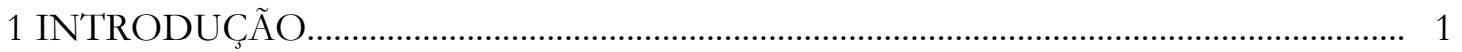

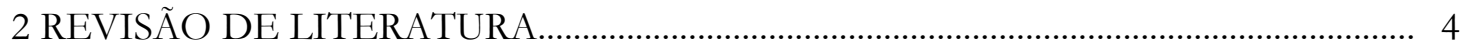

2.1 A mancha de Phaeosphaeria maydis................................................................................... 4

2.2 Avaliação da doença........................................................................................................ 7

2.3 Herança da reação à P. maydis............................................................................................... 9

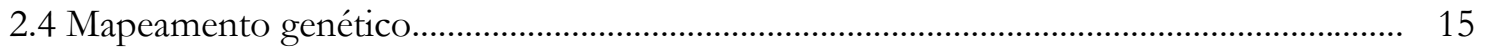

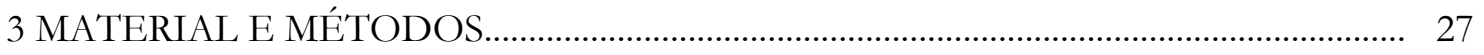

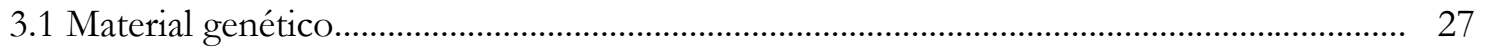

3.2 Extração, amplificação e genotipagem do DNA................................................................... 27

3.3 Mapa genético........................................................................................................... 28

3.4 Delineamento experimental, ambientes e avaliação das reações à P. maydis....................... 29

3.5 Análises de variância....................................................................................................... 31

3.6 Estimativas de parâmetros genéticos.................................................................................... 32

3.7 Análises de covariância e correlações entre ambientes.......................................................... 33

3.8 Mapeamento de QTLs.................................................................................................... 35

3.9 Valores genotípicos preditos das progênies......................................................................... 38

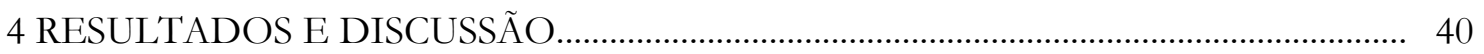

4.1 Análises de variância e parâmetros genéticos........................................................................... 40 
4.2 Mapeamento de QTLs

4.3 Comparações entre seleção assistida e com médias de progênies

4.4

Considerações

finais.

5 CONCLUSÕES

ANEXOS

REFERÊNCIAS BIBLIOGRÁFICAS. 


\section{LISTA DE FIGURAS}

Página

1 Histograma e distribuição das médias ajustadas do caráter severidade da Phaeosphaeria maydis.

2 Histograma e distribuição dos resíduos padronizados do caráter severidade da Phaeosphaeria maydis

3 Mapa genético dos cromossomos 1 a 4 . Os números à esquerda dos cromossomos são as distâncias em cM a partir do primeiro marcador e à direita estão os nomes dos marcadores microssatélites. As marcas elípticas brancas referem-se aos centrômeros, as marcas escuras e as setas à direita referem-se às posições dos QTLs de resistência/susceptibilidade à Phaeosphaeria maydis.

4 Mapa genético dos cromossomos 5 a 10 . Os números à esquerda dos cromossomos são as distâncias em cM a partir do primeiro marcador e à direita estão os nomes dos marcadores microssatélites. As marcas elípticas brancas referem-se aos centrômeros, as marcas escuras e as setas à direita referem-se às posições dos QTLs de resistência/susceptibilidade à Phaeosphaeria maydis...............

5 Mapeamento de QTLs de resistência/susceptibilidade à doença causada por Phaeosphaeria maydis no cromossomo 1 e 3 (Ph1 e Ph3). Cada pico representa um QTL, determinado pelo critério de informação Bayesiano. 
6 Mapeamento de QTLs de resistência/susceptibilidade à doença causada por Phaeosphaeria maydis no cromossomo 4 e 6 (Ph4 e Ph6). Cada pico representa um QTL, determinado pelo critério de informação Bayesiano.

7 Mapeamento de QTLs de resistência/susceptibilidade à doença causada por Phaeosphaeria maydis no cromossomo 8 (Ph8a e Ph8b). Cada pico representa um QTL, determinado pelo critério de informação Bayesiano. 


\section{LISTA DE TABELAS}

Página

1 Escala de notas usadas para a avaliação da severidade da mancha de Phaeosphaeria maydis (Agroceres, 1996)

2 Análise de variância conjunta, esperanças do quadrados médios e teste $\mathrm{F}$.

3 Análise de covariância e as esperanças dos produtos médios.

4 Valores e significâncias dos quadrados médios (QM) da análise conjunta de variância, coeficiente de variação experimental $(\mathrm{CV})$, média geral das progênies e seu intervalo de variação, e médias das linhagens parentais, para o caráter doença causada pela Phaeosphaeria maydis.

5 Valores e significâncias dos quadrados médios (QM) das análises individuais de variância, coeficiente de variação experimental (CV), médias gerais das progênies e seus respectivos intervalos de variação, dos sete ambientes para o caráter doença causada pela Phaeosphaeria maydis.

6 Estimativas das variâncias fenotípicas, de progênies, interação progênies $\mathrm{x}$ ambientes e do coeficiente de herdabilidade para o caráter doença causada pela Phaeosphaeria maydis.

7 Correlações fenotípicas entre os sete ambientes para incidência da doença causada por Phaeosphaeria maydis.. 
8 Correlações genéticas entre os sete ambientes para incidência da doença causada por Phaeosphaeria maydis

9 Correlações residuais entre os sete ambientes para incidência da doença causada por Phaeosphaeria maydis.

10 Localização, estimativas dos efeitos genéticos, epistáticos e ação gênica dos QTLs de reação à Phaeosphaeria maydis.

11 Progênies selecionadas com seus respectivos valores fenotípicos médios e valores genotípicos preditos, médias das progênies selecionadas e respectivos diferenciais de seleção 


\title{
MAPEAMENTO DE QTLs PARA REAÇÃO À DOENÇA MANCHA DE Phaeosphaeria EM MILHO
}

\author{
Autor: JOSÉ UBIRAJARA VIEIRA MOREIRA \\ Orientador: Prof. Dr. CLÁUDIO LOPES DE SOUZA JÚNIOR
}

\section{RESUMO}

A mancha foliar de Phaeosphaeria em milho (Zea mays L.) tornou-se uma preocupação no Brasil, nos últimos anos, por causa de sua ampla disseminação em áreas de cultivo. Estudos de herança da reação de genótipos de milho a essa doença foliar são necessários para dar suporte aos programas de melhoramento. Assim, o objetivo desta pesquisa foi mapear QTLs para estudar a herança e para identificar alelos favoráveis de reação à mancha foliar de Phaeosphaeria em uma população de milho tropical. Linhagens endogâmicas L 1404B e L 08-05F, altamente susceptível e altamente resistente à mancha foliar de Phaeosphaeria, respectivamente, foram utilizadas para gerar uma população $F_{2}$. Duzentas e cinqüenta seis plantas $\mathrm{F}_{2}$ foram genotipadas com 143 marcadores microssatélites, e suas progênies $\mathrm{F}_{2: 3}$ foram avaliadas em látices simples, $16 \times 16$, delineados em três estações experimentais, no ano agrícola de 2002/2003, e em quatro estações experimentais no ano agrícola de 2003/2004. A infecção artificial não foi usada, mas parcelas com o parental susceptível L-14-04B foram alocadas no início e no final de cada repetição, a cada dezesseis progênies, e como bordadura ao redor dos experimentos, para propiciar a disseminação dos esporos de P. maydis. Foram avaliadas dez plantas por parcela, aos 30 dias após o 
florescimento, por escala de notas de 1 (altamente resistente) a 9 (altamente susceptível). As médias de parcelas foram utilizadas para as análises de variância, e as médias dos ambientes foram usadas para mapear QTLs. A metodologia de mapeamento por múltiplos intervalos (MIM) foi utilizada para mapear QTLs. A análise de variância conjunta mostrou alta significância para as progênies e para a interação progênies x ambientes, mas a estimativa da variância genética foi significativamente maior que a estimativa da interação genética $\mathrm{x}$ ambientes, e o coeficiente de herdabilidade, no sentido amplo, foi alto (91,37\%). Seis QTLs foram mapeados, um para cada dos seguintes cromossomos: 1 (Ph1), 3 (Ph3), 4 (Ph4), e 6 (Ph6); e dois para o cromossomo 8 (Ph8a e Ph8b). O grau médio de dominância foi de dominância parcial, mas a ação gênica dos QTLs variou de aditiva a dominância parcial, e a epistasia do tipo dominante $\mathrm{x}$ dominante foi também detectada entre os QTLs mapeados do cromossomo 8. A variância fenotípica, explicada pelos QTLs $\left(R^{2}\right)$, variou de 2,91\% (Ph8b) a 11,86\% (Ph8a), e os efeitos conjuntos dos QTLs explicaram 41,62\% da variância fenotípica. Todos os alelos favoráveis para a reação à mancha de Phaeosphaeria; por exemplo, alelos de resistência, estavam na linhagem parental resistente L-08-05F. A correlação entre os valores de médias fenotípicas e os valores genotípicos preditos, baseados nos efeitos de QTLs das progênies, foi $r=0,70$; a seleção, baseada em ambos os critérios (médias fenotípicas e valores preditos) para a intensidade de seleção de 10\% (26 progênies) mostrou concordância de somente 46,15\% (12 progênies). Todavia, os alelos favoráveis dos QTLs, mapeados da linhagem parental resistente L-08-05F, poderão ser transferidos para outras linhagens em programas de melhoramento via retrocruzamentos assistidos por marcadores moleculares, os quais poderão ser úteis para o melhoramento. 


\title{
MAPPING QTLs FOR REACTION TO Phaeosphaeria LEAF SPOT DISEASE IN MAIZE
}

\author{
Author: JOSÉ UBIRAJARA VIEIRA MOREIRA \\ Adviser: Prof. Dr. CLÁUDIO LOPES DE SOUZA JÚNIOR
}

\section{SUMMARY}

Phaeosphaeria leaf spot disease in maize (Zea mays L.) has becoming a concern in Brazil in the last years because of its increase spreading in maize growing areas. Inheritance studies of the reaction of maize genotypes to this foliar disease are necessary to support plant breeding programs. Thus, the objective of this research was to map QTLs to study the inheritance and to identify favorable alleles for reaction to the Phaeosphaeria leaf spot in a tropical maize population. Inbred lines L 14-04B and L 08-05F, highly susceptible and highly resistant to Phaeosphaeria leaf spot, respectively, were used to develop an $F_{2}$ reference population. Two-hundred and fifty-six $\mathrm{F}_{2}$ plants were genotyped with 143 microsatellites markers, and their $F_{2: 3}$ progenies were evaluated in $16 \times 16$ simple lattice designs at three locations in the 2002/2003 growing season, and at four locations in the 2003/2004 growing season. Artificial infection was not used, but plots of the highly susceptible parental inbred L 14-04B were allocated at the beginning and at the end of each replication, at each set of sixteen progenies, and as a border all around the experiments, to provide the spread of $P$. maydis spores. Ten plants were evaluated per plot, 30 days after silk emergence, following a note scale; i.e., from 1 (highly resistant) to 9 (highly susceptible). The plot means were used 
for the analyses of variance, and the least squares means across environments were used to map QTLs. The multiple intervals mapping (MIM) was used for QTL mapping. The joint analysis of variance showed highly significance for progenies and for progenies by environment interaction, but the estimate of genetic variance was significantly greater than the estimate of the genetic by environment interaction, and the broad sense coefficient of heritability was high (91.37\%). Six QTLs were mapped, one at each of the following chromosomes: 1 (Ph1), 3 (Ph3), 4 (Ph4), and 6 (Ph6); and two at chromosome 8 (Ph8a and Ph8b). The average level of dominance was partial dominance, but the gene action of the QTLs ranged from additive to partial dominance, and dominance $\mathrm{x}$ dominance epistasis was also detected between the QTLs mapped at chromosome 8. The phenotypic variance explained by the QTLs $\left(R^{2}\right)$ ranged from $2.91 \%(\mathrm{Ph} 8 b)$ to $11.86 \%(\mathrm{Ph} 8 \mathrm{a})$, and the joint QTLs effects explained $41.62 \%$ of the phenotypic variance. All the favorable alleles to reaction to Phaeosphaeria leaf spot; i.e., resistance alleles, were in the resistant parental line L08-05F. The correlation between mean phenotypic values and the predicted genotypic values based on QTLs effects of the progenies was $r=0,70$; and the selection based under both criteria (phenotypic means and predicted values) at 10\% selection intensity (26 progenies) showed an agreement of only $46.15 \%$ (12 progenies). Nonetheless, the favorable alleles of the QTLs mapped in the parental line L 08-05F could be transferred to other inbred lines by marker-assisted backcross breeding programs, which could make them useful for breeding purposes. 


\section{INTRODUÇÃO}

A mancha de Phaeosphaeria causada pelo fungo Phaeosphaeria maydis (P. Henn.) é considerada uma doença importante em milho, tanto pela sua larga distribuição geográfica, como pelos prejuízos que tem causado aos cultivares susceptíveis (Silva, 2000). Sua ocorrência foi relatada em várias áreas tropicais e subtropicais do mundo (Carson, 1999).

Os sintomas iniciais causados por P. maydis são lesões foliares cloróticas de tamanho pequeno, que se tornam esbranquiçadas, de formato arredondado a oblonga, com 0,3 até 2,0 $\mathrm{cm}$ de diâmetro. Posteriormente, aparecem lesões aquosas verde-escuras, com os bordos bem definidos, que passam a uma coloração de pardo-escura a acinzentada e se tornam necróticas. A severidade das lesões pode aumentar e levar a uma seca prematura da planta de milho em função da susceptibilidade das variedades e do ambiente favorável de alta umidade relativa e/ou alta precipitação com temperaturas acima de $14^{\circ} \mathrm{C}$ (Fantin, 1994; Pegoraro et al., 2002; Silva, 2002).

A Phaeosphaeria maydis começou a gerar grandes perdas de produção, quando passou a antecipar seu ciclo de desenvolvimento no hospedeiro para as fases de florescimento ou a que a antecede, comprometendo o desenvolvimento da produção de grãos durante as fases seguintes, pela diminuição da área fotossintética causada pelas lesões necróticas. O surgimento antecipado da mancha de Phaeosphaeria está associado ao aumento na amplitude do cultivo do milho durante o ano, causado pelos plantios de materiais mais precoces e pela ocorrência de dois períodos de safra (safrinha e final de ano); associam-se, ainda, a esses fatores os aumentos das áreas irrigadas e o uso do sistema de plantio direto. Esse quadro incrementa o potencial de inoculação do fungo, pela permanência no campo, pois o patógeno sobrevive por meio da colonização de restos da cultura (decomposição da matéria orgânica) ou da utilização de nutrientes da solução do solo até que, sob condições 
favoráveis, os esporos germinam possibilitando a sua disseminação para novas plantas pelo vento, pelas sementes ou pela água (Fantin, 1994; Amorim, 1995b; Bedendo, 1995; Pereira, 1997; Sawazaki et al., 1997; Silva, 2000; Pegoraro et al., 2001).

O patógeno, que era considerado como causador de doença secundária e de final de ciclo, passou a ser considerado como causador de uma doença primária para a cultura do milho, havendo relatos de perdas de até 60\% (Fernandes et al., 1997; Paccola-Meirelles et al., 2001). Muitos materiais comerciais, utilizados em programas de melhoramento, apresentaram susceptibilidade. Pereira (1995) relatou que, no Brasil, em 1995, 20\% dos híbridos comercializados eram susceptíveis à $P$. maydis, 48\% tinham resistência intermediária e 32\% resistentes. Na Índia, em 1984, Das et al. (1984) avaliaram germoplasmas de milho durante um período de quatro anos e verificaram a incidência da doença causada pela $P$. maydis em 67,34\% deles, possuindo alto grau de susceptibilidade em 59,23\%. Assim, empresas e instituições de pesquisas intensificaram seus estudos para o entendimento da herança genética e para a obtenção de fontes de resistência (Silva, 2002).

Estudos genéticos visando a avaliar a resistência à $P$. maydis, demonstram que esta é uma característica quantitativa (Carson et al., 1996). Sendo assim, o acúmulo de alelos que conferem resistência contra a doença poderá levar ao desenvolvimento de materiais com nível elevado e duradouro de resistência. Para o entendimento da herança genética quantitativa deste caráter, algumas pesquisas foram realizadas por análises de médias de gerações e de cruzamentos dialélicos, indicando a presença de alta herdabilidade e a maior importância dos efeitos genéticos aditivos sobre os efeitos de dominância (Paterniani et al., 2000; Carson, 2001; Pegoraro et al., 2002; Silva, 2002; Lopes, 2003; Silva et al. 2004). No entanto Das et al. (1989a e 1989b) relatam a maior importância da ação gênica dominante comparada à ação gênica aditiva.

Recentemente, trabalhos de mapeamento de QTLs de reação de resistência, auxiliados por marcadores moleculares, vêm sendo desenvolvidos para complementar os estudos relacionados à herança genética com dados mais precisos e informativos. O mapeamento de QTLs (quantitative trait loci) permite identificar regiões cromossômicas que contêm locos que controlam o caráter. Assim, tais regiões (QTLs) podem ser tratadas como fatores mendelianos, o que pode facilitar a compreensão da arquitetura genética do caráter e, 
conseqüentemente, auxiliar os programas de melhoramento visando à incorporação de resistência à Phaeosphaeria maydis. No entanto há poucos relatos na literatura sobre o mapeamento de QTLs para reação de resistência à $P$. maydis, principalmente relacionados a materiais de clima tropical. Lopes (2003) mapeou QTLs de reação de resistência à P. maydis em progênies de milho tropical e, pelo mapeamento por intervalo composto (CIM), encontrou 5 QTLs, um nos cromossomos 1, 2 e 5; e dois QTLs no cromossomo 4. Carson et al. (1996) mapearam germoplasma de clima temperado pela análise de regressão de marcas simples e encontraram QTLs de reação de resistência à $P$. maydis no braço curto do cromossomo 7 e no braço longo dos cromossomos 8 e 10. Carson et al. (2004) mapearam QTLs de reação de resistência em linhagens puras recombinantes do cruzamento das linhagens de clima temperado e, pela análise de mapeamento por intervalo composto (CIM), identificaram cinco QTLs em três diferentes cromossomos, com uma interação aditivo x aditivo. Comentam ainda que encontraram resultados de alta herdabilidade e a predominância de efeitos gênicos aditivos.

Nesse contexto, os objetivos deste trabalho foram mapear QTLs que controlam a reação de resistência à Phaeosphaeria maydis em milho de clima tropical, estimar os efeitos gênicos desses QTLs e comparar a seleção com base nos valores genotípicos das progênies e à seleção com base nas médias fenotípicas das mesmas. 


\section{REVISÃO DE LITERATURA}

\subsection{A mancha de Phaeosphaeria maydis}

O primeiro relato da mancha de Phaeosphaeria maydis foi feito por Hennings (1902), citando que sintoma da doença ocorria no Estado de São Paulo, Brasil. Posteriormente, ocorrências da doença foram relatadas em países da Ásia, da África, e das Américas do Sul, Central e do Norte, mostrando que a doença está amplamente disseminada por vários países (Rane et al., 1965; Fantin, 1994; Carson, 1999 e 2001).

O agente causador da mancha foliar de Phaeosphaeria é um fungo ascomiceto e foi descrito por Rane et al. (1965) como Phaeosphaeria maydis (P. Henn.). Anteriormente, fora denominado por Hennings (1902) Sphaerulina maydis, sendo a sua fase imperfeita correspondente a Phyllosticta sp. Há controvérsias sobre o agente etiológico da doença, principalmente devido à dificuldade em se reproduzirem sintomas a partir de inoculações com os esporos do fungo. Paccola-Meirelles et al. (2001 e 2002) estudaram o agente etiológico causador da doença da mancha de Phaeosphaeria, por análises citológicas de lesões, por isolamento do microorganismo e por teste de patogenicidade em casa de vegetação, em 79 híbridos de milho da EMBRAPA/CNPMS de Sete lagoas/MG. Os autores relataram a presença do fungo $P$. maydis apenas nos estádios finais de desenvolvimento da doença e isolaram a bactéria Pantoea ananas (syn. Erwinia ananas) das lesões da mancha de Phaeosphaeria. Plantas de milho foram inoculadas com isolado desta bactéria e sintomas típicos da doença foram observados novamente apenas nas plantas inoculadas com a bactéria. Tais resultados foram indicativos de que a bactéria Pantoea ananas (syn. Erwinia ananas) está envolvida na fase inicial da doença, favorecendo a posterior ação da Phaeosphaeria maydis.

Os primeiros sintomas causados por $P$. maydis são lesões foliares basais que progridem rapidamente para as folhas superiores da planta. As lesões são cloróticas, de 
tamanho pequeno, e se tornam esbranquiçadas, de formato arredondado a oblonga, com 0,3 até 2,0 cm de diâmetro. Posteriormente, aparecem lesões aquosas verde-escuras, com os bordos bem definidos, que passam a uma coloração de pardo-escura a acinzentada. Na fase mais adiantada de desenvolvimento, as lesões necróticas apresentam estruturas reprodutivas, picnídios e pseudotécios, como pontuações escuras localizadas ao centro. Os picnídios possuem estruturas de cor marrom escuro a preto, ostíolos arredondados, com conídios hialinos, elipsóides, alongados ou arredondados. Os pseudotécios possuem os ostíolos papilados, o asco é hialino, clavado ou cilíndrico, reto ou curvo, contendo oito ascósporos de forma hialinas, reta ou ligeiramente curva, com três septos ligeiramente constritos e com a região central dilatada (Fantin, 1994; Pereira, 1997; Pegoraro et al., 2002; Silva, 2002; Lopes, 2003).

As condições climáticas ideais para o desenvolvimento da doença são temperaturas moderadas, com alta umidade relativa, principalmente quando a temperatura se eleva logo após uma chuva (Fantin, 1994). Segundo Pinto (1997), em experimentos conduzidos na região de Sete Lagoas/MG (EMBRAPA/CNPMS), a doença alcançou altos níveis de severidade, quando os valores de temperatura mínima do ar e a média de umidade relativa foram iguais ou superiores a $14^{\circ} \mathrm{C}$ e $60 \%$, respectivamente, ou quando a temperatura mínima do ar foi inferior a $14^{\circ} \mathrm{C}$, mas com a umidade relativa superior a $65 \%$. Em temperatura superior a $14^{\circ} \mathrm{C}$ e umidade relativa inferior a $60 \%$ não houve ocorrência da doença, indicando que a umidade relativa foi o fator determinante para o aparecimento das lesões foliares causadas pelo fungo. Em regiões com altitude superior a 700 m, a ocorrência da doença é devida à quantidade elevada de orvalho (Silva, 2000).

A P. maydis é um parasita necrotrófico, isto é, que mata a célula do hospedeiro antes de invadi-lo e a sua sobrevivência é garantida pela atividade saprofítica, que pode se dar por meio da colonização de restos da cultura (decomposição da matéria orgânica) ou da utilização de nutrientes da solução do solo para obter seus alimentos. Dessa forma, o fungo permanece no campo, incrementando o potencial de inoculação para anos posteriores; sob condições favoráveis, os esporos germinam, possibilitando a disseminação dos propágulos para novas plantas por meio do vento, das sementes ou da água. O vento e as sementes são 
responsáveis pela dispersão a longas distâncias, enquanto a água promove a distribuição do patógeno nas proximidades da fonte do inóculo (Fantin, 1994; Amorim, 1995b; Bedendo, 1995; Pereira, 1997; Silva, 2000; Pegoraro et al., 2001).

As estruturas do patógeno podem ocorrer em várias partes vegetativas da planta, tais como brácteas e palhas da espiga. A contaminação de plantas nos estádios finais do ciclo da cultura resulta no desenvolvimento de poucas lesões distribuídas por toda a planta. O estabelecimento sobre plantas de milho depois de atingirem a maturação não tem causado prejuízos significativos (Silva, 2002). Entretanto o aumento da área cultivada com o sistema de plantio direto, o cultivo de duas safras ao ano, a ausência de cultivares resistentes ou com nível adequado de resistência e as condições climáticas favoráveis proporcionaram um incremento na severidade da doença, que passou a se manifestar em plantas mais jovens, aumentando os danos à produção. Dessa forma, a mancha de P. maydis tornou-se atualmente uma doença primária, estando entre as principais doenças foliares em milho no Brasil (Balmer et al., 1987; Von Pinho, 1998).

A incidência da mancha Phaeosphaeria em materiais susceptíveis antes ou durante o florescimento poderá proporcionar à planta um aspecto de queima intensa, causando seca prematura das folhas e redução no ciclo da planta pela diminuição da área fotossintética. As perdas em produtividade de grãos podem chegar a $60 \%$, dependendo das condições ambientais (Agroceres, 1996; Fernandes \& Oliveira, 1997; Pegoraro et al., 1998 e 2001).

Segundo Fantin (1994), na década de 1980 foram observadas lesões com severidade de até 50\% no estado do Paraná. Em algumas regiões, a ocorrência da doença adquiriu caráter endêmico, limitando o cultivo de materiais susceptíveis no plantio safrinha, quando se tem constatado maior severidade da doença; avaliações de campo mostraram que materiais comerciais apresentaram até $40 \%$ da sua área foliar afetada pelo patógeno (Embrapa, 1993; Dudienas et al., 1998). Segundo Godoy et al. (1998), tem-se observado que a infecção pelo patógeno da Phaeosphaeria maydis na planta tem um efeito maior na fotossíntese que o esperado pela quantidade da área da planta coberta por lesões visíveis, folhas com severidades próximas a $20 \%$ tiveram a taxa fotossintética reduzida em até $50 \%$. 
Segundo Silva (2002), as fontes primárias de inóculo não foram ainda determinadas para a cultura do milho no Brasil. As possibilidades são de que os focos iniciais da doença sejam da cultura safrinha, plantas de milho germinadas das sementes da resteva de verão, outras espécies hospedeiras ou que o inóculo advenha de áreas de plantio de inverno do Nordeste, ou mesmo de outros continentes. Mas algumas medidas gerais de controle podem colaborar para diminuir o inóculo e os danos do patógeno, como a rotação de culturas, a eliminação de restos culturais, a adubação balanceada e evitar plantios tardios. Pinto (1997) comenta a eficiência do uso de fungicidas do tipo mancozeb no controle de P. maydis. No entanto a utilização de produtos químicos para o controle de doenças na cultura do milho é, normalmente, inviável do ponto de vista econômico (Brasil et al., 1998). Assim, o uso de cultivares resistentes é o método de controle mais eficiente para a doença causada pela $P$. maydis (Bedendo, 1995; Pereira, 1997; Casela et al., 2002).

\subsection{Avaliação da doença}

O parâmetro severidade é o mais apropriado para quantificar doenças foliares como ferrugens, oídios, míldios e manchas. Entende-se por severidade a porcentagem da área ou do volume de tecido da planta cobertos por sintomas. Outros termos fitopatológicos que quantificam a gravidade de doenças são a incidência, que é a porcentagem de plantas doentes em uma amostra ou população, e a intensidade, que é um termo mais amplo e pode ser expresso como severidade e incidência (Amorim, 1995a).

A avaliação da severidade de doença pode ser realizada pela utilização de chaves descritivas, de escalas diagramáticas e de análises de imagens. Em avaliações de doenças foliares há predomínio de escalas diagramáticas, sendo elas representações ilustradas de uma série de plantas com diferentes níveis de severidade. No Brasil, a escala diagramática mais utilizada para a avaliação da mancha de Phaeosphaeria é a de Chester (1950), modificada por Agroceres (1996). A avaliação pode ser feita na planta inteira ou na folha posicionada abaixo do ponto de inserção da espiga principal. No caso da mancha de Phaeosphaeria, o método de avaliação da severidade da doença na planta inteira mostrou-se mais preciso e prático (Silva, 2002). 
Um aspecto importante na avaliação das doenças do milho é a caracterização do estádio fenológico de desenvolvimento do hospedeiro, pois o efeito da doença na produção varia de acordo com a época em que a planta foi infectada (Silva, 2002). Segundo Agroceres (1996), o estádio fenológico ideal para a avaliação da $P$. maydis é o 7 , devido à maior incidência da doença nessa fase, que ocorre entre 20 e 25 dias após a emissão dos estilosestigmas, quando os grãos do milho apresentam consistência pastosa.

A época ideal de avaliação é o período em que a doença apresenta maior incidência, por permitir discriminar os tipos de reações dos genótipos em relação ao patógeno. Segundo Silva (2002), vários autores indicam que há aumento da doença a partir de setembro, ocorrendo a sua maior incidência nos meses de dezembro a fevereiro. Pegoraro et al. (2001), avaliando o efeito de cinco épocas de semeadura e em dois níveis de adubação na mancha de Phaeosphaeria, relataram que, na medida em que a semeadura do milho foi retardada, houve aumento na severidade da doença e redução no rendimento de grãos. Os meses de novembro e dezembro apresentaram os maiores valores de severidade. Isso se deve à ocorrência de temperatura e umidade adequadas ao desenvolvimento do patógeno (Sawazaki et al., 1997).

A avaliação da doença pode ser também realizada pela curva de progresso da doença. Neste caso, a mancha de P. maydis é observada em vários estádios fenológicos; assim, a melhor representação da reação do hospedeiro é dada pelo seu desempenho ao longo de uma epidemia, a qual pode ser graficamente ilustrada pela quantidade da doença em função do tempo (Lopes, 2003). Algumas considerações a favor desta metodologia são apontadas, como maior segurança nas inferências sobre a epidemia quando comparada a estudos baseados em uma única avaliação, e menor influência dos efeitos de época de avaliação e ambiente (Parlevliet, 1979; Campbell et al., 1990). No entanto este método está voltado aos estudos epidemiológicos e a aplicação prática é trabalhosa, por requerer, pelo menos, três avaliações do mesmo indivíduo. Quando há experimentos avaliados com vários tratamentos, repetições e ambientes, torna-se inviável sua aplicação.

Lopes (2003), em seu trabalho de mapeamento de genes de resistência à P. maydis utilizou a curva de progresso da doença para três épocas de avaliação da severidade à $P$. 
maydis: no florescimento, 15 e 30 dias após o florescimento. Este autor relata a dificuldade prática da avaliação da curva de progresso e, pelo estudo de correlações entre os dados da curva e as três épocas de avaliações pontuais, concluiu que as avaliações pontuais de 15 e 30 dias após o florescimento são mais práticas e tão informativas quanto a curva de progresso.

\subsection{Herança da reação à $P$. maydis}

Os mecanismos genéticos de reações aos patógenos desenvolvidos pelas plantas podem gerar os efeitos de resistência ou de susceptibilidade. A classificação com base no número de genes envolvidos considera dois tipos de resistências: monogênica e poligênica. A resistência monogênica ou qualitativa, acontece quando a presença de um único gene é suficiente para conferir resistência, inexistindo reações intermediárias na ausência de outras fontes de variação que não a genética, e representada pela distribuição fenotípica descontínua. A resistência poligênica, ou quantitativa, é caracterizada pela presença de vários genes controlando o caráter pela presença de uma distribuição contínua de níveis de resistência (Camargo, 1995).

Os conhecimentos a respeito dos caracteres quantitativos e da herança do caráter são importantes para a condução adequada e para a otimização dos resultados dos programas de melhoramento. Obtêm-se tais informações por meio de estudos biométricos e de análises de experimentos com repetições e delineamentos genéticos específicos. Usando cruzamentos controlados entre genitores com fenótipos contrastantes, os melhoristas estimam a herdabilidade, o número de locos relevantes associados à expressão do caráter, o grau de dominância, a aditividade, a heterose e a magnitude das interações gene-gene e geneambiente (Tanksley, 1993). Esses estudos focam as distribuições fenotípicas dentro das populações e suas correlações com os fenótipos dos indivíduos relacionados. Os resultados de tais estudos fornecem informações importantes a respeito da base genética dos caracteres quantitativos e do progresso com a seleção em programas de melhoramento (Lee, 1995). Os trabalhos de mapeamento de genes de reação de resistência por meio de marcadores moleculares têm contribuído, também, para um melhor entendimento sobre a herança genética da reação de plantas a fitopatógenos. 
Trabalhos sobre a herança genética da mancha de $P$. maydis são escassos; mas, estudos da doença indicam possuir a herança genética quantitativa, prevalecendo na maioria dessas pesquisas, a alta herdabilidade e os efeitos gênicos aditivos sobre os efeitos de dominância (Paterniani et al., 2000; Carson, 2001; Pegoraro et al., 2002; Silva, 2002; Lopes, 2003; Silva et al. 2004).

Paterniani et al. (2000) avaliaram híbridos simples de milho tropical de cruzamentos dialélicos entre dez linhagens endogâmicas em quatro locais. Os experimentos em delineamentos de blocos ao acaso, com três repetições, foram avaliados 30 dias após o florescimento por escala diagramática de notas (Agroceres) para reação a Phaeosphaeria maydis e Puccinia Polysora. Os resultados para a doença P. maydis apresentaram CEC e CGC significativos, mas a magnitude da CGC indicou que os efeitos aditivos foram mais importantes que os dominantes, no controle dessa doença.

Pegoraro et al. (2002) estudaram a herança da reação à P. maydis de sete linhagens de milho, pela análise dialélica e por médias de gerações. Para a análise dialélica, os experimentos foram em delineamento em blocos casualizados, com três repetições; fez-se a avaliação após 30 dias do florescimento com base na infestação natural do fungo e inferiu-se sobre a média da porcentagem da área foliar afetada pela P. maydis na parcela. $\mathrm{Na}$ análise de média de gerações utilizou-se o cruzamento de todas as combinações possíveis de duas linhagens resistentes e uma susceptível, avaliando as gerações $P_{1}, P_{2}, F_{1}$ e $F_{2}$ em experimentos de parcelas subdivididas, com duas repetições. Realizou-se a avaliação de severidade da $P$. maydis da mesma forma que o experimento de análise dialélica, mas avaliando plantas individuais. As análises dialélicas indicaram significância na CGC e CEC, mas os valores sugeriram a maior importância dos efeitos de aditividade (CGC) sobre os efeitos de dominância (CEC), além da presença de efeitos epistáticos. Em todos os cruzamentos observaram-se grande variabilidade genética para a reação de resistência à $P$. maydis e os altos valores estimados de herdabilidade, sugerindo a obtenção de ganhos genéticos com a seleção fenotípica de indivíduos resistentes em gerações segregantes. Concluiu-se pelas freqüências dos indivíduos $\mathrm{F}_{2}$ a presença de três genes de efeitos 
pronunciados governando o caráter de resistência à $P$. maydis e de outros genes de menores efeitos.

Silva (2002) e, posteriormente, Silva et al. (2004) estudaram a análise dialélica da reação de resistência em milho com nove linhagens endogâmicas, sendo três linhagens resistentes, três moderadamente resistentes, uma linhagem moderadamente susceptível e duas linhagens susceptíveis. Os experimentos de blocos ao acaso, com três repetições, foram instalados em três ambientes. A severidade da doença foi avaliada no estádio fenológico 7 por meio de dois métodos, a escala diagramática de 1 a 9 na planta inteira (PI) e a avaliação da severidade da doença na folha posicionada abaixo do ponto de inserção da espiga principal (AFA), usando-se a escala diagramática da porcentagem da área foliar afetada. Apenas o efeito de CGC foi significativo, evidenciando que os efeitos genéticos aditivos são mais importantes como fonte de variação para a reação de resistência à doença. Os resultados para os dois métodos de avaliação foram praticamente idênticos, mas os autores indicaram o método PI, que apresenta maior praticidade de uso. Deste mesmo trabalho, Silva (2002) avaliou três linhagens susceptíveis em cruzamento com quatro linhagens resistentes, pela análise de médias de gerações, em dois ambientes. As gerações utilizadas foram $\mathrm{F}_{1}, \mathrm{~F}_{2}$ e o retrocruzamento ocorreu com os dois parentais. Tal estudo de herança da reação de resistência à $P$. maydis também indicou a maior importância do efeito genético aditivo sobre os efeitos de dominância, sendo que, em média, os efeitos genéticos dominantes contabilizaram menos de $10 \%$ da variação entre as médias de gerações. As estimativas da herdabilidade no sentido amplo foram altas, variando de 82,10 a 92,80\% para PI e 63,40 a 77,80\% para AFA. Estimaram-se três genes envolvidos na reação de resistência à P. maydis.

Lopes (2003) utilizou a análise de média de gerações para estudar a herança da reação de resistência à $P$. maydis em três linhagens tropicais de milho. O material utilizado foi idêntico ao de Silva (2002), sendo, neste caso, uma linhagem resistente, uma linhagem moderadamente resistente e uma linhagem susceptível. O cruzamento da linhagem resistente e moderadamente resistente com a linhagem susceptível formou duas populações que produziram as gerações $\mathrm{F}_{1}, \mathrm{~F}_{2}$ e o retrocruzamento com cada genitor em estudo. $\mathrm{O}$ 
delineamento empregado foi de blocos ao acaso com três repetições, sendo as parcelas constituídas pelas gerações. Utilizou-se de material susceptível como bordadura para a contaminação natural dos experimentos em campo e as avaliações foram em planta inteira, 30 dias após o florescimento, com base na escala diagramática de notas da Agroceres (1996). $\mathrm{O}$ autor comenta que os efeitos genéticos aditivos foram mais importantes na determinação do caráter de resistência, com participação menor dos efeitos dominantes para as duas populações estudadas; as estimativas de herdabilidade, no sentido amplo, foram altas (63\% e $71 \%)$.

Carson (2001) estudou a herança da reação de resistência à P. maydis pela análise de média de gerações do cruzamento das linhagens de clima temperado endogâmicas Mo17 (resistente) e B73 (susceptível). Os genitores e suas gerações $\mathrm{F}_{1}, \mathrm{~F}_{2}$ e o retrocruzamento com cada genitor foram avaliados em experimentos de blocos ao acaso, com três repetições, sendo a avaliação feita por escala diagramática de notas de 0 a 9 , no estádio de grão na forma de dente. Foi constatada significância dos efeitos genéticos de aditividade e de dominância, não se encontrando evidência de epistasia. Os efeitos genéticos aditivos foram superiores em relação aos efeitos de dominância e as estimativas da herdabilidade foram altas, tanto no sentido amplo (85\%) como no restrito (70\%).

Os trabalhos relatados a respeito da ação gênica envolvida no controle da reação de resistência à P. maydis divergem de Das et al. (1989a). Estes autores encontraram efeitos significativos da CEC e CGC, em análise de cruzamentos dialélicos envolvendo nove variedades de polinização aberta de milho, com os efeitos genéticos dominantes como o principal componente genético em relação aos efeitos aditivos. Posteriormente, Das et al. (1989b) analisaram, em cruzamentos dialélicos, oito variedades de polinização aberta diferentes das do trabalho anterior e constataram os mesmos resultados obtidos anteriormente.

Os trabalhos de mapeamento de reação de resistência vêm sendo desenvolvidos para complementar os estudos relacionados à herança genética, com dados mais precisos e informativos. No entanto há poucos relatos, na literatura, sobre esses trabalhos, principalmente os relacionados a materiais de clima tropical. Lopes (2003) realizou um 
estudo de mapeamento de QTLs de reação de resistência à P. maydis do cruzamento de duas linhagens de clima tropical, que foram genotipadas por marcadores microssatélites e por AFLPs. Progênies $F_{2: 3}$ foram avaliadas em dois experimentos em látice $11 \times 11$, com três repetições. Utilizou-se de material susceptível como bordadura para a contaminação natural dos experimentos em campo e as avaliações foram em planta inteira no florescimento, no $15^{\circ}$ e no $30^{\circ}$ dia após o florescimento, com base na escala diagramática de notas da Agroceres (1996). Além das avaliações pontuais nesses períodos, foram calculadas as curvas de progresso da doença para as três avaliações. O autor concluiu que avaliações pontuais de 15 e 30 dias após o florescimento são mais práticas e tão informativas quanto a curva de progresso. Pela metodologia de mapeamento por intervalo composto, para os resultados da média dos experimentos, foram identificados oito QTLs na avaliação durante o período do florescimento, sete QTLs para a avaliação aos 15 dias após florescimento, cinco QTLs na avaliação aos 30 dias após o florescimento e seis QTLs para a avaliação utilizando a curva de progresso da doença. Foram localizados um QTL nos cromossomos 1, 2 e 5 e dois QTLs no cromossomo 4 na avaliação de 30 dias após florescimento; a proporção da variação fenotípica explicada por esses QTLs variou de 9,81 a 32,87\%. Já a avaliação pela curva de progresso da doença localizou um QTL nos cromossomos 1 e 5, e dois QTLs, nos cromossomos 2 e 4; a proporção da variação fenotípica explicada por tais QTLs variou de 9,89 a 55,60\%. Ao considerar todas as avaliações pelo mapeamento por intervalo composto, o autor relata que foram mapeados QTLs associados à reação de resistência em 10 intervalos, sendo um QTL nos cromossomos 5, 6 e 9; dois QTLs nos cromossomos 1 e 2, e três QTLs, no cromossomo 4.

Carson et al. (1996) mapearam QTLs de reação de resistência à P. maydis em 179 linhagens puras recombinantes do cruzamento das linhagens de clima temperado B73 (susceptível) e Mo17 (resistente). As linhagens puras recombinantes foram genotipadas por marcadores RFLP, por isoenzimas e por microssatélites; a análise de regressão de marcas simples permitiu a identificação de QTLs no braço curto do cromossomo 7 e no braço longo dos cromossomos 8 e 10. Os autores comentam que os QTLs explicaram 23\% da variação fenotípica. 
Carson et al. (2004) comentam o recente surgimento da doença causada pela $P$. maydis no sul da Flórida (EUA), gerando uma preocupação com a susceptibilidade de muitas linhagens endogâmicas utilizadas na produção de híbridos comerciais naquele país. No interesse de identificar QTLs de reação de resistência à doença, e para aumentar os níveis de resistência dos materiais utilizados em programas de melhoramento, os autores realizaram um estudo de mapeamento de QTLs com 158 linhagens puras recombinantes do cruzamento das linhagens de clima temperado B73 e Mo17. Os parentais e seus $\mathrm{F}_{1}$ s foram avaliados quanto à reação de resistência à $P$. maydis, em experimentos com repetições em duas épocas. Pela análise de mapeamento por intervalo composto (CIM) identificaram-se cinco QTLs em três diferentes cromossomos e uma interação aditiva x aditiva. Os autores comentam que os resultados de alta herdabilidade e a maior importância dos efeitos gênicos aditivos encontrados neste trabalho estão em concordância com o trabalho de média de gerações dos mesmos materiais realizados por Carson et al. (2001).

O predomínio de poucos QTLs, de ação gênica aditiva e a alta herdabilidade da reação de resistência à $P$. maydis indicam que os métodos de melhoramento de populações e de seleção de progênies a empregar poderão ser conduzidos com níveis elevados de seleção, pressupondo que os ganhos genéticos também sejam elevados. A seleção massal para a resistência à $P$. maydis deverá fornecer um progresso rápido no melhoramento de populações de milho e os métodos genealógicos e de retrocruzamento podem ser eficientes na obtenção de linhagens resistentes (Silva, 2002).

A continuidade dos trabalhos sobre herança genética de reação à $P$. maydis agregará informações necessárias para auxiliar a condução experimental e os estudos relacionados ao melhoramento genético de resistência à doença. Entre tais contribuições, citam-se: a identificação, a clonagem, a transformação gênica e a caracterização desses genes, a transferência para outras populações de interesse, bem como, o aumento na compreensão e na eficiência de seleção e de geração de materiais comerciais resistentes. 


\subsection{Mapeamento genético}

A maioria dos caracteres de importância agronômica, que se avaliam em programas de melhoramento de plantas, é determinada por vários locos, apresenta variação contínua e, influenciados pelo ambiente, tais caracteres são denominados de quantitativos. Os locos gênicos que afetam um caráter quantitativo são denominados QTLs (Quantitative Trait Loci), podendo ser um único gene ou um segmento do cromossomo (Mather \& Jinks, 1984; Ramalho et al., 1993; Falconer \& Mackay, 1996).

O mapeamento genético consiste em fazer inferências sobre a relação entre os valores fenotípicos de caracteres quantitativos e os genótipos dos QTLs no genoma. O número e as posições dos QTLs são determinados no genoma e os efeitos de aditividade, de dominância, de epistasia, de pleiotropia e a interação QTL x ambientes são estimados. No entanto mapas genéticos saturados com algum tipo de marcador associados a esses QTLs, são necessários para inferir sobre qual o provável genótipo dos QTLs, já que estes não são observados, e, sim, os marcadores. Diferentemente do mapeamento genético, o conceito de mapa genético está relacionado às representações gráficas e estatísticas dos cromossomos de uma espécie, indicando a ordenação dos locos nos cromossomos, bem como as distâncias relativas entre eles, sejam tais locos associados a genes ou não (Lynch \& Walsh, 1998; Griffiths et al., 2000).

O termo marcador tem sido utilizado para designar fatores morfológicos, fisiológicos, bioquímicos ou genéticos passíveis de serem identificados e que permitem o estudo comparativo de genótipos e de suas progênies (Sakiyama, 1993). Marcadores genéticos têm sido usados para estudar características herdadas quantitativamente, nos últimos 70 anos (Stuber et al., 1992a). A ligação entre um marcador genético e um QTL foi primeiramente demonstrada por Sax (1923), que detectou que a mudança da cor do tegumento da semente (caráter simples - marcador) de Phaseolus estava ligada à variação do tamanho médio da semente (caráter quantitativo - QTL) (Paterson et al., 1991). Ele interpretou o fato como uma ligação do gene que controla a cor com um ou mais dos poligenes que controlam o tamanho da semente. 
Esses marcadores morfológicos correspondem a caracteres de fácil identificação visual, como nanismo, deficiência clorofítica, cor de pétalas ou morfologia foliar e contribuíram significativamente para o desenvolvimento teórico da análise de ligação gênica e para a construção das primeiras versões de mapas genéticos. Os caracteres são de avaliação bastante simples e de baixo custo. No entanto, por se apresentarem em número reduzido e, em muitos casos, com variabilidade restrita, hoje têm aplicação menos freqüente na análise genética (Borém, 1998; Ferreira \& Gratapaglia, 1998).

Tal situação foi modificada com o desenvolvimento de marcadores bioquímicos/isoenzimáticos, na década de 1960, e dos marcadores moleculares, a partir da década de 1970. Por definição, os marcadores genéticos bioquímicos são produtos da expressão gênica (proteínas ou compostos secundários). São geralmente codominantes por permitirem a distinção entre homozigotos e heterozigotos e podem ser facilmente avaliados em uma grande quantidade de espécies, apresentando uma variabilidade superior à dos marcadores morfológicos. Apresentam custo muito reduzido e permitem a obtenção relativamente rápida dos dados (Conte, 2004). Entretanto apresentam polimorfismo limitado, sendo pouco abundantes, o que reduz o potencial de utilização da técnica (Murphy et al., 1990). Além disso, podem estar sujeitos à influência do ambiente (Richards, 1997).

Com o surgimento de técnicas modernas para marcadores genéticos moleculares, na década de 1970, pôde-se analisar o polimorfismo genético em organismos vivos em nível de DNA. A primeira técnica desenvolvida foi a análise de polimorfismo de comprimento de fragmentos de restrição de DNA, o RFLP (Restriction Fragment Length Polymorphism). A técnica baseia-se na clivagem, por enzima de restrições, em sítios específicos (sítios de restrição) do DNA, extraído da espécie de interesse. Os fragmentos produzidos são separados através de eletroforese em gel de agarose e visualizados pelo processo de "Southern Blot" (Southern, 1975, Robinson, 1998). Com o mesmo processo de obtenção de RFLPs, pode-se obter outro tipo de marcador que são os minissatélites ou VNTR (Variable Number of Tandem), regiões dispersas no genoma constituído de um número variável de seqüências idênticas, repetidas lado a lado (Ferreira \& Gratapaglia, 1998; Conte, 2004). 
Durante a década de 1980, Mullis \& Faloona (1987) desenvolveram a técnica da reação da polimerase em cadeia PCR (Polymerase Chain Reaction) permitindo o surgimento de marcadores como AFLP (Amplified Fragment Length Polymorphism), RAPD (Random Amplified Polymorphic DNA) e SSR (Simple Sequence Repeats) ou microssatélites. A facilidade, a versatilidade e a sensibilidade tornaram a PCR uma técnica importante para os estudos genético-moleculares, devido à possibilidade de se gerar em grandes quantidades de DNA específicos do genoma, facilitando a detecção, a olho nu, diretamente em gel de eletroforese, através de corantes específicos para DNA, como o Brometo de Etídio. (Ferreira \& Gratapaglia, 1998).

Entre os marcadores morfológicos, bioquímicos (isoenzimáticos) e moleculares (RFLP, AFLP, RAPD e SSR), os marcadores moleculares são os mais utilizados atualmente no estudo do genoma de plantas e animais (Souza, 2001). Estes marcadores dividem-se em duas classes: codominantes e dominantes. Os codominantes são espécie-específicos e permitem a visualização simultânea dos alelos de um mesmo loco, podendo-se visualizar três combinações alélicas. Encontram-se nesta classe os RFLPs e os SSRs. Os dominantes não permitem a visualização simultânea dos alelos de um mesmo loco, podendo-se identificar apenas duas classes genotípicas. Enquadram-se, nesta classe, os RAPDs e AFLPs.

Um marcador ideal deve apresentar polimorfismo entre os genitores e segregação mendeliana para a população obtida. Outros aspectos são importantes na escolha do marcador, tais como custo por unidade de genotipagem, neutralidade fenotípica e abundância dos marcadores moleculares no genoma, além de haver uma estreita ligação entre o loco marcador e o caráter de interesse e da facilidade com que os marcadores podem ser utilizados (Tanksley, 1993; Dudley, 1993; Sênior et al., 1996).

Segundo Lynch \& Walsh (1998), os procedimentos iniciais de estudos de QTLs visam, primeiramente, ao emprego de delineamentos genéticos apropriados; em segundo, à construção de mapas genéticos de ligação com o maior número possível de marcas (saturados) e, finalmente, a aplicação de análises de mapeamento dos QTLs com o uso de métodos e de estatísticas específicos. 
Os principais delineamentos utilizados a fim de se obterem populações segregantes para os estudos de mapeamento genético são populações $\mathrm{F}_{2}$, retrocruzamentos (Backcrosses), linhagens endogâmicas recombinantes (Recombinant Inbred Lines) e linhagens duplo-haplóides. Tais delineamentos utilizam linhagens homozigóticas como genitores, fenotipicamente divergentes (contrastantes) para o caráter em estudo, para gerar populações segregantes com o máximo de desequilíbrio de ligação. Os desvios em relação às proporções esperadas pela segregação independente de alelos de locos marcadores e QTLs é que permitem a detecção e o mapeamento dos QTLs (Bearzoti, 2000).

O desequilíbrio pode ser decorrente de diversas causas, incluindo seleção e deriva genética. Entretanto a causa predominante em populações segregantes, derivadas de cruzamentos entre linhagens, é a ligação física dos locos. O desequilíbrio de ligação, devido à ligação física dos locos, é bastante elevado nas populações de cruzamentos controlados. Conseqüentemente, a capacidade de se detectar a ligação entre os dois locos fisicamente ligados também é alta (Tanksley, 1993; Falconer \& Mackay, 1996; Lynch \& Walsh, 1998).

Populações $F_{2}$ são obtidas da autofecundação de indivíduos $F_{1}$, gerados a partir do cruzamento entre duas linhagens genitoras homozigóticas $\left(\mathrm{P}_{1}\right.$ e $\left.\mathrm{P}_{2}\right)$ contrastantes para o caráter de interesse. Segundo Young (1994), a população $F_{2}$ é a mais indicada para a construção de mapas, por atingir o máximo de desequilíbrio de ligação. Entretanto, nesta população, a avaliação dos caracteres e a genotipagem são efetuados para cada planta em separado, aumentando a variação experimental e diminuindo a precisão da detecção ou do mapeamento de QTLs. Em situações em que a avaliação de um determinado caráter exige ensaios em vários locais, há o fato inconveniente de os indivíduos utilizados serem únicos ou poucos numerosos. $\mathrm{O}$ problema pode ser superado, utilizando-se populações $\mathrm{F}_{2: 3}$, resultantes da autofecundação de populações $\mathrm{F}_{2}$, abrindo-se, de cada planta dessa população autofecundada, uma linha de plantio, gerando várias progênies $F_{2: 3}$. Neste caso, as plantas $F_{2}$ são genotipadas enquanto o caráter quantitativo, associado ao genótipo individual, é estimado pelo valor médio das progênies $F_{2: 3 .}$. $O$ delineamento com população $F_{2}$ permite a construção de mapas tão precisos quanto os obtidos com o dobro de indivíduos oriundos de 
delineamentos de retrocruzamentos. Conseqüentemente, há uma redução considerável do esforço necessário em termos de avaliação genotípica (Lynch \& Walsh, 1998).

É interessante comentar que o poder de detecção de um QTL será tanto maior, quanto maior for o número de marcadores disponíveis e de indivíduos genotipados e avaliados para os caracteres quantitativos. Estudos teóricos iniciais sugeriram uma população acima de 1000 indivíduos para estudos de associações de marcadores e de QTLs. Entretanto verificou-se que, para a detecção da segregação de QTLs nessas populações, o número de indivíduos poderia ser menor, entre 100 e 300 indivíduos. O tamanho da amostra da população deve ser o maior possível, dentro da capacidade de trabalho da equipe envolvida e dos recursos financeiros disponíveis (Edwards et al., 1987; Stuber et al., 1987; Lander \& Botstein, 1989; Young, 1994).

Com os dados de populações segregantes gerados de delineamentos específicos $\left(\mathrm{F}_{2}\right.$, retrocruzamentos etc.) e com os indivíduos analisados, por meio do uso de algum tipo de marcador genético, a etapa seguinte é a construção de mapas genéticos de ligação. Esta etapa envolve as análises de teste de segregação, para verificar o padrão de segregação, o teste de ligação, para detectar o desequilíbrio de ligação, e a ordenação das marcas, a partir das distâncias entre elas.

Para verificar se cada marca segue a segregação mendeliana são realizados testes de $\chi^{2}$ (Qui-quadrado), testando se não há diferenças significativas entre as freqüências observadas das classes fenotípicas dos marcadores e aquelas esperadas conforme o delineamento e o tipo de marcadores empregados. Ao adotar um determinado nível de significância para múltiplos testes independentes, poderá ocorrer erro do tipo I (falso positivo), em que se rejeita uma hipótese sendo ela verdadeira. Este erro induz o descarte incorreto de marcadores, ou seja, são descontadas marcas que seguem a segregação mendeliana. Uma forma de contornar o problema é utilizar a correção de Bonferroni, que consiste em obter o nível de significância conjunto, considerando-se todas as marcas empregadas (Sokal \& Rohlf, 1995; Lynch \& Walsh, 1998). Para exemplificar, o nível de significância para cada marcador pode ser obtido dividindo-se o nível de significância global $(\gamma)$ pelo número de marcadores empregados $(\eta)$, assim, tendo $\gamma=0,05$ e $\eta=100$ marcas, 
teremos o nível de significância de $\alpha=0,0005$, ou seja, a probabilidade de descartar marcadores incorretamente é de 5 em 10 mil marcadores empregados, considerando que não haja desvios significativos entre as freqüências observadas e as esperadas. Antes eram 5 descartes incorretos em 100 marcas empregadas (nível de significância de 5\%).

Uma forma mais adequada de se obter o limite de significância, considerando-se todo o genoma, é determinar tal limite empiricamente, através de testes de permutação. Tais testes consistem em repetir a análise dos dados diversas vezes, reamostrando aleatoriamente e sem reposição dos dados originais em cada repetição. Para um limite empírico de 5\% de significância, normalmente 1000 reamostragens são suficientes (Churchill \& Doerge, 1994; Doerge \& Churchill, 1996; Mackay, 2001).

Após a análise de segregação, é realizado o teste de ligação para verificar a ocorrência de desequilíbrio de ligação entre os pares de marcas que apresentaram segregação mendeliana. Esta análise de ligação tem por objetivo determinar as marcas que estão ligadas entre si, formando um conjunto para cada cromossomo. Esse conjunto é denominado de grupo de ligação e, para sua construção são consideradas duas marcas de cada vez, testando-se estatisticamente o valor da freqüência de recombinação. Deve-se testar se a freqüência de recombinação é significativamente diferente de 0,5 , o que geralmente é feito com o uso do teste de razão de verossimilhança (LR), ou equivalentes, como o LOD score (Lynch \& Walsh, 1998).

É importante enfatizar que as distâncias entre os genes não são distâncias físicas e, sim, genéticas, as quais são calculadas pela freqüência de recombinantes. Portanto, faz-se necessária a transformação de escala para o cálculo das distâncias entre genes, para tornar as freqüências de recombinação em medidas aditivas de distância. Um grande número de funções de mapeamento, as quais relacionam medidas de distâncias às freqüências de recombinantes, foram desenvolvidas: Haldane (1919), Ludwig (1934), Kosambi (1944), Carter \& Falconer (1951), Rao et al. (1977), Felsenstein (1979), Karlin \& Liberman (1978 e 1979), Karlin (1982), Pascoe \& Morton (1987), Ott (1991). No mapeamento genético de plantas, as funções de Haldane (1919) e Kosambi (1944) são ainda as mais utilizadas para se relacionar a distância genética entre dois locos no mapa e a freqüência de gametas 
recombinantes: a primeira supõe falta de interferência, enquanto a segunda, uma quantidade moderada de interferência. A interferência é causada pela possibilidade de ocorrência de "crossing-over"; à medida que a distância entre locos aumenta, cresce também a probabilidade de ocorrência desse tipo de evento e, conseqüentemente, menos precisa é a utilização da freqüência de recombinação para estimar a distância (Lynch \& Walsh, 1998; Griffiths et al., 2000).

Tendo avaliado a segregação e obtido os grupos de ligação pelas freqüências de recombinação entre pares de marcas, a fase seguinte envolve mensurar as distâncias com base na análise multipontos, permitindo ordená-las dentro de cada grupo de ligação. Devemse obter todas as ordens possíveis para um conjunto de marcas, calculando-se a máxima verossimilhança de cada uma delas. A melhor ordem é aquela que tiver a maior verossimilhança para tal conjunto (Lynch \& Walsh, 1998). O inconveniente deste método é que quando a análise envolve um número muito grande de locos, o número de ordens possíveis pode tornar o procedimento impraticável. O número de ordens possíveis para $\eta$ locos é igual a $\eta ! / 2$. Para $\eta=30$ genes temos, por exemplo, $1.33 \times 10^{32}$ combinações possíveis.

Como houve um grande aumento no número de marcas utilizadas na construção dos mapas e aumento do número de indivíduos genotipados, surgiu a necessidade do desenvolvimento de vários algoritmos e de programas computacionais para a construção de mapas genéticos, como o Mapmaker/EXP (Lander, et al., 1987; Lincoln et al., 1992), Gmendel (Liu \& Knapp, 1992) e o JoinMap (Stam, 1993). O programa Mapmaker/EXP (Lander, et al., 1987; Lincoln et al., 1992) é de fácil utilização e engloba vários algoritmos traduzidos em comandos que possibilitam a mensuração e a ordenação de grande quantidade de marcas.

A partir dos delineamentos genéticos e da construção de mapas genéticos de ligação, a etapa seguinte envolve o mapeamento de QTLs, com o uso de metodologias estatísticas específicas. Os principais métodos de mapeamento são: o método de análise de marcas simples (Stuber et al., 1987), o mapeamento por intervalo (Lander \& Botstein, 1989), o mapeamento por intervalo composto (Jansen \& Stam, 1994; Zeng, 1994), sua 
extensão pelo mapeamento de múltiplos caracteres (Jiang \& Zeng, 1995) e o mapeamento por múltiplos intervalos (Kao et al., 1999). A análise de marcas simples utiliza, normalmente, algum modelo linear, enquanto os métodos de mapeamento por intervalo, por intervalo composto e de múltiplos intervalos utilizam métodos de máxima verossimilhança, baseados na informação da distribuição conjunta dos marcadores e dos QTLs (Lynch \& Walsh, 1998; Liu, 1998; Garcia, 2003).

O método de análise de marca simples (single marker analysis) é utilizado para uma abordagem inicial no mapeamento de QTLs e fornece a base para o desenvolvimento de outros métodos de mapeamento mais complexos. Nessa análise, a distribuição dos valores do caráter é examinada separadamente, para cada loco marcador. Assim, cada teste de associação caráter-marcador é realizado independentemente da informação dos outros locos marcadores. Para um cromossomo $\operatorname{com} n$ marcas, $n$ testes são realizados. A estratégia para detectar QTLs, nesta análise, é fundamentada na comparação entre os valores médios da característica associados aos diferentes genótipos marcadores. Uma diferença significativa entre as médias das classes genotípicas dos marcadores indica a possibilidade da presença de pelo menos um QTL associado ao marcador. Quando o delineamento experimental apresenta somente duas classes genotípicas, como no caso de retrocruzamentos, a comparação entre eles pode ser realizada através do teste $t$, para verificar se há diferença significativa, que é atribuída ao efeito do marcador ligado a um ou mais QTLs. Caso haja mais que duas classes genotípicas, as comparações são realizadas usando-se testes padrões da teoria de modelos lineares, tais como teste $F$ em análises de variância ou modelos de regressão linear (Lynch \& Walsh, 1998; Liu, 1998).

Uma outra possibilidade para verificar se há ligação entre QTL e marca, na análise de marca simples, é o uso do método da máxima verossimilhança. A vantagem desse método é estimar a posição do QTL, separando-se a frequência de recombinação dos efeitos aditivos e a de dominância.

Segundo Lynch \& Walsh (1998), toda a teoria formal de mapeamento de QTLs está fundamentada em probabilidades condicionais, que é a probabilidade de ocorrência do genótipo $Q_{k}$ do QTL na população, dada a ocorrência do genótipo marcador $M_{j}$. Essa 
probabilidade é função do delineamento experimental, empregado para produzir as populações, e do mapa de ligação. A partir dessas probabilidades, é possível calcular os valores médios do caráter para os vários genótipos marcadores e estimar os efeitos dos QTLs pelo método da máxima verossimilhança.

O teste de significância desses parâmetros é feito pela razão de verossimilhança (LR). Segundo Lynch \& Walsh (1998), a estatística da razão de verossimilhança (LR) é feita pela razão da função da máxima verossimilhança, sob a hipótese de que há ligação e sob a hipótese nula de que não há ligação. Esse teste estatístico tem distribuição aproximada de $\chi^{2}$, com os graus de liberdade dados pelo número de ajuste de parâmetros do modelo total. Para facilitar a interpretação do teste, foi introduzida, por Lander \& Botstein (1989), a estatística do LOD score ( $\log$ of the odds), que consiste em utilizar a estatística da razão de verossimilhança convertida para o logaritmo na base 10. Valores elevados desse LOD favorecem a hipótese de ligação, enquanto valores próximos de 2 fornecem evidência de segregação independente. Em geral, consideram-se ligados locos que apresentam valores de LOD superiores ou iguais a 3; este valor indica que a hipótese alternativa é $10^{3}=1000$ vezes mais provável que a hipótese nula (Griffiths et al., 2000; Borecki \& Suarez, 2001; Garcia, 2003).

Para facilitar a visualização e a tomada de decisão pela significância desses parâmetros, constroem-se curvas formadas pelos valores calculados de cada razão de verossimilhança ou LOD em cada posição do cromossomo, avaliada em função das distâncias do cromossomo. Picos da curva que ultrapassam o ponto limite (threshold), estabelecido com uso de reamostragens (ou com base em dados da literatura), indicam a possibilidade de existência de um QTL naquela posição.

As metodologias estatísticas para identificar a associação de QTL com marcadores moleculares são auxiliadas por programas computacionais que fornecem rapidez na execução. Entre tais programas, o QTLCartographer para windows vs. 2.0 - WinQTLCart (Wang et al., 2004) disponibiliza um sistema interativo que engloba várias metodologias existentes para mapear QTLs. 
A segunda metodologia é o mapeamento por intervalo, apresentada por Lander \& Botstein (1989). Essa metodologia baseia-se em probabilidades condicionais de um par de marcas adjacentes flanqueando um QTL pontual, diferentemente do método de análise de marcas simples que compara as médias fenotípicas de diferentes grupos alélicos dos marcadores. O método por intervalo combina a análise de marcas simples com a estatística de máxima verossimilhança, permitindo que sejam estimados todos os parâmetros envolvidos na análise, como a média $(\mu)$, o efeito dos QTLs $\left(\beta^{*}\right)$, a variância $\left(\sigma^{2}\right)$ e a distância entre o QTL e as marcas $\left(M_{j}\right.$ e $\left.M_{j+1}\right)$, o que torna o mapeamento mais preciso que o método de análise de marcas simples (Lander \& Botstein, 1989; Lynch \& Walsh, 1998; Liu, 1998).

A desvantagem do método é isolar o intervalo analisado do restante do genoma, desconsiderando os efeitos de outros QTLs próximos ao QTL contido no intervalo. Esse problema causa o surgimento de "QTLs fantasmas", provenientes da indicação de valores de razões de verossimilhança maiores que o limite de significância em regiões genômicas onde não há QTLs (Lynch \& Walsh, 1998; Garcia, 2003).

O terceiro método é o mapeamento por intervalo composto (Composite Interval Mapping - CIM) que é uma extensão do mapeamento por intervalo com regressão linear múltipla, visando a diminuir a interferência de QTLs adjacentes ao intervalo que está sendo mapeado. Neste método, além dos pares de marcadores adjacentes, marcas são selecionadas como cofatores, permitindo controlar os efeitos de outros QTLs, enquanto o QTL do intervalo de interesse é investigado. A seleção dos cofatores (marcas) poderá ser feita pelo processo de regressão "stepwise", "backward" ou "forward". Da mesma forma que o mapeamento por intervalo, o CIM baseia-se nas probabilidades condicionais e na estatística de máximo verossimilhança, permitindo estimar parâmetros como a média $(\mu)$, o efeito dos QTLs $\left(\beta^{*}\right)$, a variância $\left(\sigma^{2}\right)$ e o efeito das marcas $\left(\beta_{k}\right)$, em que $\beta_{k}$ corresponde aos coeficientes da regressão múltipla. Além de estimar a posição do QTL, o método permite testar a significância dos efeitos principais dos QTLs pela razão de verossimilhança ou LOD score (Zeng, 1994). 
A principal vantagem é a utilização de marcas significativas como cofatores $\left(\beta_{k}\right)$, resolvendo o problema de falsos QTLs. Entre as desvantagens do CIM, o uso de marcadores fortemente ligados como cofatores pode reduzir o poder do teste estatístico na detecção de QTLs; além disso, a contribuição conjunta $\left(r^{2}\right)$ dos QTLs ligados em relação à variância fenotípica é de difícil estimação.

Uma extensão do CIM foi proposta como mapeamento de múltiplos caracteres (mCIM) por Jiang \& Zeng (1995). O mCIM permite analisar múltiplos caracteres correlacionados ou ainda analisar um único caráter em múltiplos ambientes, visando a estudar a interação QTLs x ambientes. A análise conjunta dos dados deste modelo fornece a vantagem de melhorar o poder estatístico do teste para a presença de QTL e a precisão da estimação dos parâmetros. Esse tipo de análise permite, entre os vários testes, verificar os efeitos de pleiotropia dos QTLs, o mapeamento conjunto, a interação de QTL x ambiente e pleiotropia x efeito de ligação. Para estudar-se a interação QTLs x ambientes, para um dado caráter, utiliza-se o mesmo modelo, porém passa a considerar-se o número de ambientes em que os indivíduos foram avaliados, para o caráter em questão (Jiang \& Zeng, 1995).

O quarto método é a técnica de mapeamento por múltiplos intervalos (Multiple Interval Mapping - MIM), apresentado por Kao et al. (1999) com base no modelo de Cockerham (1954) para a interpretação de parâmetros genéticos, e em probabilidades condicionais; associa-se ao método da máxima verossimilhança, para a estimação de parâmetros genéticos. Com o uso do MIM, pode-se obter um aumento na precisão e no poder da detecção de QTLs por meio da estimação do número de QTLs, das posições genômicas, dos efeitos e das interações de QTLs (epistasia) e a sua contribuição para a variância genética. A idéia do MIM é ajustar os efeitos de múltiplos QTLs e associar os efeitos de epistasias diretamente com um modelo que facilita a procura, o teste e a estimação das posições, dos efeitos e das interações dos QTLs. O MIM combina análise de mapeamento de QTL com análises de arquitetura genética de caracteres quantitativos (Kao et al., 1999; Zeng et al., 1999).

As vantagens dessa metodologia são aumentar a eficiência e a precisão na identificação e na estimação da posição dos QTLs, e permitir estudar os efeitos epistáticos, o 
que garante o aumento da eficiência da seleção assistida por marcadores, por predizer valores genotípicos individuais. Entre as desvantagens, até o momento, está a impossibilidade de se analisar múltiplos caracteres ou um caráter em vários ambientes, como o mCIM faz.

Com o desenvolvimento e o aperfeiçoamento das técnicas de marcadores genéticos e de mapeamento de QTLs, houve um acréscimo significativo de informações genéticas de populações e de indivíduos utilizados em estudos biológicos e em programas de melhoramento. Entre as principais aplicações do mapeamento de QTLs de reação a doenças, têm-se: a identificação e a localização de QTLs com grandes efeitos individuais, a seleção dos indivíduos a partir de informações diretas de seu genótipo, a possibilidade de transferir os QTLs a outras populações de interesse, a incorporação das informações do genótipo obtido via marcadores moleculares para o uso em seleção assistida por marcadores (SAM) e melhorar o conhecimento das correlações genéticas entre caracteres. 


\section{MATERIAL E MÉTODOS}

\subsection{Material genético}

Foram utilizadas 256 progênies $\mathrm{F}_{2: 3}$ derivadas do cruzamento das linhagens endogâmicas L 14-04B e L 08-05F. A linhagem L-14-04B foi obtida da população BR-106 e liberada pela EMBRAPA/Milho e Sorgo; apresenta características de ciclo tardio, porte alto e grãos amarelos dentados. A linhagem L-08-05F foi obtida da população IG-1 e liberada pelo programa de melhoramento de milho do Departamento de Genética da ESALQ/USP; apresenta características de ciclo precoce, porte baixo e grãos alaranjados duros (flint). As populações e suas respectivas linhagens pertencem a grupos heteróticos distintos (Souza Jr. et al., 1993). Tais linhagens são contrastantes para diversos caracteres, incluindo o nível de resistência/susceptibilidade à $P$. maydis. A linhagem L 14-04B é altamente susceptível, enquanto a L 08-05F é resistente (Tabela 4).

Essas linhagens foram cruzadas e plantas da geração $F_{1}$ foram autofecundadas para a obtenção da geração $F_{2}$ e plantas desta geração foram autofecundadas, gerando as 256 progênies $\mathrm{F}_{2: 3}$ utilizadas neste estudo.

\subsection{Extração, amplificação e genotipagem do DNA}

Foram coletadas uma ou duas folhas das plantas $\mathrm{F}_{2}$ que deram origem às progênies $F_{2: 3}$. As folhas foram acondicionadas em sacos de sombrite e armazenadas em recipiente com gelo e transportadas para o laboratório CEBMEG/UNICAMP. No mesmo dia, foram congeladas em nitrogênio líquido, a $-70^{\circ} \mathrm{C}$. Posteriormente, realizaram-se a liofilização e a moagem das amostras, as quais foram armazenadas em frascos específicos e congeladas a $-20^{\circ} \mathrm{C}$. A extração de DNA foi realizada segundo o protocolo descrito por Hoisington et al. (1994), utilizando-se $50 \mathrm{mg}$ de tecido liofilizado e moído, tampão de 
extração CTAB ("Mixed alkyltrimethyl-ammonium bromide") e duas extrações sucessivas em clorofórmio/álcool isoamílico (24:1). O DNA de cada amostra foi submetido a uma extração final com fenol, para garantir maior pureza.

As 256 plantas $\mathrm{F}_{2}$ foram genotipadas por 178 marcadores moleculares microssatélites. Estes foram obtidos após a realização de testes de amplificação/polimorfismo para 859 pares de primers. As sequências de nucleotídeos para a síntese dos primers foram obtidas na página PCR Primer Pairs for Microsatellites da Universidade de Missouri-Columbia (http://www.maizegdb.org).

O procedimento utilizado para amplificar o DNA foi desenvolvido por Don et al. (1991), para a análise de microssatélites em milho; é denominado de Touchdown PCR, com algumas modificações. A metodologia de amplificação do DNA e a visualização da genotipagem adotada neste trabalho foram descritas em detalhes por Sibov et al. (2003).

\subsection{Mapa genético}

Foram selecionados 143 marcadores moleculares microssatélites que não apresentaram desvios significativos de segregação de 1:2:1 pelo teste do qui-quadrado. Este teste utilizou o nível de significância de $5 \%$ de probabilidade $(\alpha)$ corrigido pelo critério de Bonferroni (Province, 2001). Este critério foi adotado pela necessidade de se obter um nível de significância conjunto para testes múltiplos, pressupondo que os testes sejam independentes, o que não ocorre quando os marcadores estão no mesmo cromossomo.

O mapa de ligação genético foi construído utilizando-se o programa Mapmaker versão 3.0 (Lander et al., 1987; Lincoln et al., 1992). As análises de ligação foram inferidas, a partir de um LOD de valor mínimo de 3,0 e com $50 \mathrm{cM}$ de distância máxima entre dois locus para formar os grupos de ligação; as freqüências de recombinação entre marcadores foram convertidas para as distâncias em cM pela função de mapeamento de Kosambi (Kosambi, 1944). A análise de dois pontos foi realizada para estimar as freqüências de recombinações pela máxima verossimilhança; já o comando "group" foi estabelecido para obter os grupos de ligação. A ordenação das marcas do grupo de ligação foi obtida pela comparação das verossimilhanças de todas as ordens possíveis, através do comando 
“compare". Usou-se um número de marcas inferior ou igual a 10, para a ordenação através deste comando; para grupos de ligação com mais de 10 marcas, foram selecionados subconjuntos formados pelas marcas mais informativas e ordenadas entre si, que serviram como referência para a inserção das marcas restantes, feitas pelo comando "try". A ordenação mais provável foi determinada com base na máxima verossimilhança e a consistência dos resultados foi verificada através do comando "ripple". Foram construídos 10 grupos de ligações, equivalentes aos 10 cromossomos do genoma do milho.

\subsection{Delineamento experimental, ambientes e avaliação das reações à $P$. maydis}

As 256 progênies $\mathrm{F}_{2: 3}$ foram avaliadas em látice $16 \times 16$ em sete ambientes e com duas repetições por ambiente. Cada parcela foi constituída de uma linha de 4,00 m, com espaçamento de $0,80 \mathrm{~m}$ entre linhas e $0,20 \mathrm{~m}$ entre plantas. No momento da semeadura, foram distribuídas 50 sementes por parcela e, após 30 dias, foi realizado o desbaste, deixando-se 20 plantas competitivas na parcela, que corresponde a um estande de 62.500 plantas ha-1.

Os experimentos foram conduzidos em dois anos agrícolas. Cada combinação entre anos agrícolas e locais foi considerada como um ambiente distinto, perfazendo um total de sete ambientes:

Ambiente 1: Estação Experimental do Departamento de Genética ESALQ/USP, ano agrícola 2002/2003, semeado em 14 de novembro de 2002;

Ambiente 2: Estação Experimental da Fazenda Caterpillar, ano agrícola de 2002/2003, semeado em 28 de novembro de 2002;

Ambiente 3: Estação Experimental da Fazenda Areão, ano agrícola de 2002/2003, semeado em 07 de dezembro de 2002;

Ambiente 4: Estação Experimental da Fazenda Anhembi, ano agrícola 2002/2003, semeado em 02 de dezembro de 2002;

Ambiente 5: Estação Experimental do Departamento de Genética ESALQ/USP, ano agrícola 2003/2004, semeado em 26 de novembro de 2003; 
Ambiente 6: Estação Experimental da Fazenda Caterpillar, ano agrícola de 2003/2004, semeado em 02 de dezembro de 2003;

Ambiente 7: Estação Experimental da Fazenda Anhembi, ano agrícola 2003/2004, semeado em 18 de dezembro de 2003.

Os tratos culturais seguiram as recomendações técnicas de cada ambiente, sendo os experimentos irrigados, quando necessário, na Estação Experimental do Departamento de Genética e no Anhembi.

Para assegurar a presença e a multiplicação do patógeno, a linhagem susceptível L14-04B foi plantada como bordadura nas laterais, na frente e atrás dos experimentos, e intercalada a cada 16 parcelas, perfazendo um total de 32 parcelas por experimento. Além disso, os dois parentais (L 14-04B e L 08-05F) foram plantados em parcelas pareadas, no início e no final de cada repetição dos experimentos, para avaliar as suas médias.

As avaliações da severidade de Phaeosphaeria maydis foram realizadas 30 dias após o florescimento feminino, em 10 plantas por parcela, com o uso da escala diagramática da Agroceres (1996), que considera as escalas de notas em relação à porcentagem da área foliar infectada (Tabela 1).

Tabela 1. Escala de notas usadas para a avaliação da severidade da mancha de Phaeosphaeria maydis (Agroceres, 1996)

\begin{tabular}{cc}
\hline Nota & Área foliar infectada $(\%)$ \\
1 & 0 \\
2 & 1 \\
3 & 1 a 10 \\
4 & 10 a 20 \\
5 & 20 a 30 \\
6 & 30 a 40 \\
7 & 40 a 60 \\
8 & 60 a 80 \\
9 & $>80$ \\
\hline
\end{tabular}

A severidade da doença foi avaliada por quatro pessoas em cada experimento, duas por repetição. Em cada parcela, as cinco plantas iniciais foram avaliadas por um dos avaliadores e as cinco plantas finais da parcela avaliadas pelo outro avaliador. Foram dadas 
notas para cada planta e o valor de cada parcela correspondeu à média das 10 plantas avaliadas.

\subsection{Análises de variância}

Inicialmente, foram realizadas análises de variância para cada experimento. Considerou-se o modelo aleatório, cujo modelo matemático foi (Cochran \& Cox, 1966):

$$
y_{i j k}=\mu+r_{j}+b_{k(j)}+p_{i}+e_{i j k}
$$

em que:

$y_{i j k}$ : é o valor observado da progênie $i$, na repetição $j$, no bloco $k$;

$\mu$ : é a média geral do experimento;

$r_{j}$ : é o efeito da repetição $j(j=1,2)$;

$b_{k(j)}$ : é o efeito do bloco $k$ dentro da repetição $j(k=1,2, \ldots, 16)$;

$p_{i}$ : é o efeito da progênie $i(i=1,2, \ldots, 256)$;

$e_{i j k}$ : é o erro associado à observação $y_{i j k}$.

Posteriormente, realizou-se a análise conjunta, cujo modelo matemático foi:

$$
y_{i j k l}=\mu+r_{j(l)}+b_{k(j / l)}+p_{i}+a_{l}+p a_{i l}+e_{i j k l}
$$

em que:

$y_{i j k l}$ : é o valor observado da progênie $i$, da repetição $j$, no bloco $k$, no ambiente $l$;

$\mu$ : é a média geral do experimento;

$r_{j}$ : é o efeito da repetição $j(j=1,2)$;

$b_{k(j)}$ : é o efeito do bloco $k$ dentro da repetição $j(k=1,2, \ldots, 16)$;

$p_{i}$ : é o efeito da progênie $i(i=1,2, \ldots, 256)$;

$a_{l}$ : é o efeito do ambiente $l(l=1,2, \ldots, 7)$;

$p a_{i l}$ : é o efeito aleatório da interação progênie $i$ e ambiente $l$;

$e_{i j k l}:$ é o erro associado à observação $y_{i j k l}$. 
Foram feitos os testes de normalidade de Shapiro-Wilk, para verificar o comportamento da distribuição dos resíduos, e o teste do $F$ máximo, para verificar a homogeneidade das variâncias (Steel \& Torrie, 1980). Todas as análises foram realizadas utilizando-se o programa do SAS (SAS INSTITUTE, 1999).

O esquema da análise de variância conjunta, com as respectivas esperanças dos quadrados médios está apresentado na Tabela 2:

Tabela 2. Análise de variância conjunta, esperanças do quadrados médios e teste $F$

\begin{tabular}{lcccc}
\hline \multicolumn{1}{c}{ Fonte de variação } & GL & QM & E (QM) & F \\
\hline Ambientes (A) & $a-1$ & - & - & - \\
Repetições (R) / A & $a(r-1)$ & - & - & - \\
Blocos / A / R & $a r(k-1)$ & - & - & - \\
Progênies (P) & $p-1$ & $Q M_{P}$ & $\sigma^{2}+r \sigma_{p a}^{2}+r a \sigma_{p}^{2}$ & $Q M_{P} / Q M_{P A}$ \\
Progênies x Ambientes & $(p-1)(a-1)$ & $Q M_{P A}$ & $\sigma^{2}+r \sigma_{p a}^{2}$ & $Q M_{P A} / Q M_{R}$ \\
Resíduo & - & $Q M_{R}$ & $\sigma^{2}$ & - \\
\hline
\end{tabular}

$a, r, k, p$ referem-se ao número de ambientes, repetições, blocos e progênies, respectivamente

\subsection{Estimativas de parâmetros genéticos}

A partir das esperanças dos quadrados médios da análise de variância conjunta, foram estimados os seguintes parâmetros:

Variância de progênies $\left(\hat{\sigma}_{p}^{2}\right)$ :

$$
\hat{\sigma}_{p}^{2}=\frac{Q M_{P}-Q M_{P A}}{r a}
$$

Variância da interação progênies x ambientes $\left(\hat{\sigma}_{p a}^{2}\right)$ :

$$
\hat{\sigma}_{p a}^{2}=\frac{Q M_{P A}-Q M_{R}}{r}
$$

Variância do resíduo $\left(\hat{\sigma}^{2}\right)$ :

$$
\hat{\sigma}^{2}=Q M_{R}
$$

Variância fenotípica $\left(\hat{\sigma}_{\bar{F}}^{2}\right)$ :

$$
\hat{\sigma}_{\bar{F}}^{2}=\frac{Q M_{P}}{r a}
$$


Coeficiente de herdabilidade de médias de progênies $\mathrm{F}_{2: 3}\left(\hat{h}_{\bar{p}}^{2}\right)$ :

$$
\hat{h}_{\bar{p}}^{2}=\frac{\hat{\sigma}_{p}^{2}}{\hat{\sigma}_{\bar{F}}^{2}}
$$

Os intervalos de confiança (IC) dos componentes de variância a 95\% de probabilidade foram obtidos seguindo os procedimentos descritos por Barbin (1993):

$$
\operatorname{IC}\left(\hat{\sigma}^{2}\right)_{0,95}=\left[\frac{n t \hat{\sigma}^{2}}{\chi_{n t ; 0,975}^{2}} \leq \sigma^{2} \leq \frac{n t \hat{\sigma}^{2}}{\chi_{n t ; 0,025}^{2}}\right]
$$

em que:

$n t$ : o número de graus de liberdade associado à estimativa do componente de variância $\left(\hat{\sigma}^{2}\right)$

$\chi_{n t ; 0975}^{2}$ e $\chi_{n t ; 0,025}^{2}$ : referem-se ao valor tabelado de $\chi^{2}$ com $n t$ graus de liberdade com 97,50\% e 2,50\% de probabilidade, respectivamente. O número de graus de liberdade foi estimado utilizando-se o procedimento de Satterthwaite (1946).

O intervalo de confiança da estimativa do coeficiente de herdabilidade de médias de progênies a 95\% de probabilidade foi obtido segundo a expressão discutida por Knapp et al. (1985):

$$
I C\left(\hat{h}_{\bar{x}}^{2}\right)_{0,95}=\left\{1-\frac{1}{\left(\frac{Q M_{p}}{Q M_{p a}}\right) F_{0,975 ; G L p ; G L p a}} \leq h_{\bar{x}}^{2} \leq 1-\frac{1}{\left(\frac{Q M_{p}}{Q M_{p a}}\right) F_{0,025 ; G L p ; G L p a}}\right\}
$$

em que:

$F_{0,975 ; G L p ; G L p a}$ e $F_{0,025 ; G L ; ; G L p a}$ : referem-se ao valor tabelado de $F$ a $97,50 \%$ e $2,50 \%$ de probabilidade, respectivamente, com os graus de liberdade de progênies (GLp) e graus de liberdade da interação progênies por ambientes (GLpa).

\subsection{Análises de covariância e correlações entre ambientes}

Foram estimados os coeficientes de correlação genética, fenotípica e dos erros ambientais (resíduo) entre os 7 ambientes em que as progênies foram avaliadas. Para isso, 
foram realizadas análises de variâncias para cada par de ambientes ( $x$ e $y$ ) e para a soma dos valores das parcelas desses ambientes $(x+y)$. Os produtos médios $\left(P M_{x y}\right)$ de cada fonte de variação foram definidos segundo a metodologia descrita por Steel \& Torrie (1980):

$$
P M_{x y}=\frac{1}{2}\left(Q M_{x+y}-Q M_{x}-Q M_{y}\right)
$$

em que:

$Q M_{X+y}, Q M_{x}$ e $Q M_{y}:$ referem-se aos quadrados médios das análises da soma dos ambientes $x$ e $y$ e dos ambientes $x$ e $y$, respectivamente.

A análise de covariância para os pares de ambientes está representada na Tabela 3:

Tabela 3. Análise de covariância e as esperanças dos produtos médios

\begin{tabular}{lccc}
\multicolumn{1}{c}{ Fonte de variação } & GL & PM & E (PM) \\
\hline Repetições (R) & $(r-1)$ & - & - \\
Blocos / R & $r(k-1)$ & - & - \\
Progênies (P) & $p-1$ & $P M_{P x y}$ & $C_{R x y}+r C O V_{P x y}$ \\
Resíduo & - & $P M_{R x y}$ & $C_{R x y}$ \\
\hline
\end{tabular}

$r, k$ e $p$ referem-se ao número repetições, blocos e progênies, respectivamente

Das análises de covariâncias estimaram-se:

Covariância de progênies $\left(C O V_{P x y}\right)$ :

$$
C O V_{P x y}=\frac{P M_{P x y}-P M_{R x y}}{r}
$$

Covariância do ambiente (resíduo) $\left(\operatorname{COV}_{R x y}\right)$ :

$$
C O V_{R x y}=P M_{R x y}
$$

Covariância fenotípica média $\left(\operatorname{COV}_{\bar{F} \times y}\right)$ :

$$
C O V_{\bar{F} x y}=\frac{P M_{P x y}}{r}
$$

em que:

$P M_{P x y}$ : é o produto médio de progênies da análise de covariância entre ambientes;

$P M_{R x y}$ : é o produto médio do resíduo da análise de covariância entre ambientes. 
A partir desses parâmetros genéticos, foram estimadas as correlações genética $\left(\hat{r}_{G X y}\right)$, ambiental $\left(\hat{r}_{R x y}\right)$ e fenotípica $\left(r_{\bar{F} x y}\right)$ entre os ambientes $x$ e $y$, respectivamente:

$$
\begin{gathered}
\hat{r}_{G x y}=\frac{C \hat{O} V_{p x y}}{\sqrt{\hat{\sigma}_{p x}^{2} \hat{\sigma}_{p y}^{2}}} \\
\hat{r}_{R x y}=\frac{C \hat{O} V_{R x y}}{\sqrt{\hat{\sigma}_{R x}^{2} \hat{\sigma}_{R y}^{2}}} \\
\hat{r}_{\bar{F} x y}=\frac{C \hat{O} V_{\bar{F} x y}}{\sqrt{\hat{\sigma}_{\bar{F} x}^{2} \hat{\sigma}_{\bar{F} y}^{2}}}
\end{gathered}
$$

em que:

$\hat{\sigma}_{p x}^{2}$ e $\hat{\sigma}_{p y}^{2}$ : são as estimativas das variâncias de progênies dos ambientes $x$ e $y$;

$\hat{\sigma}_{R x}^{2}$ e $\hat{\sigma}_{R y}^{2}$ : são as estimativas das variâncias residuais dos ambientes $x$ e $y$;

$\hat{\sigma}_{\bar{F} x}^{2}$ e $\hat{\sigma}_{\overline{F y}}^{2}$ : são as estimativas das variâncias fenotípicas dos ambientes $x$ e $y$, respectivamente.

Utilizou-se o teste de $t$ de Student para testar se a correlação fenotípica difere de zero $(\rho \neq 0)$, calculada pela seguinte expressão (Steel \& Torrie, 1980):

$$
t=\frac{\hat{r}_{\bar{F}_{x y}}}{\sqrt{\left(1-\hat{r}_{\bar{F}_{x y}}\right) /(n-2)}}
$$

em que:

$n$ : é o número de progênies avaliadas $(n=256)$;

$\hat{r}_{\bar{F} x y}:$ é a estimativa da correlação fenotípica.

As correlações genéticas foram testadas segundo a metodologia descrita por Falconer \& Mackay (1996).

\subsection{Mapeamento de QTLs}

Para o mapeamento de QTLs, a estimação de seus efeitos genéticos, de suas posições e a análise dos efeitos de interação entre QTLs (epistasia), usou-se a metodologia 
de Mapeamento por Múltiplos Intervalos (Multiple Interval Mapping - MIM), descrita por Kao et al. (1999). As análises foram realizadas pelo programa Windows QTL Cartographer vs. 2.0 - WinQTLCart (Wang et al., 2004), de acordo com os procedimentos descritos no manual do QTL Cartographer 1.17 (Basten et al., 2003).

O modelo assume que vários QTLs se localizam em várias posições, em diferentes intervalos entre várias marcas, controlando um caráter quantitativo ao longo do genoma. Assim, segundo Zeng (1999), o modelo MIM foi:

$$
y_{i}=\mu+\sum_{j=1}^{m} a_{j} x_{i j}^{*}+\sum_{j=1}^{m} d_{j} z_{i j}^{*}+\sum_{j \neq k}^{t} a_{j} a_{k} x_{i j}^{*} x_{i k}^{*}+\sum_{j \neq k}^{t} a_{j} d_{k} x_{i j}^{*} z_{i k}^{*}+\sum_{j \neq k}^{t} d_{j} a_{k} z_{i j}^{*} x_{i k}^{*}+\sum_{j \neq k}^{t} d_{j} d_{k} z_{i j}^{*} x_{i k}^{*}+e_{i}
$$

em que:

$y_{i}$ : é o valor fenotípico do caráter quantitativo da $i$-ésima progênie;

$\mu$ : é a média geral;

$\alpha_{j}$ : é o efeito aditivo do $j$-ésimo QTL;

$d_{j}$ : é o efeito dominante do $j$-ésimo QTL;

$a_{j} a_{k}$ : é o efeito epistático aditivo por aditivo entre o $j$-ésimo e o $k$-ésimo QTLs;

$a_{j} d_{k}$ :é o efeito epistático aditivo por dominante entre o $j$-ésimo e o $k$-ésimo QTLs;

$d_{j} a_{k}$ : é o efeito epistático dominante por aditivo entre o $j$-ésimo e o $k$-ésimo QTLs;

$d_{j} d_{k}$ : é o efeito epistático dominante por dominante entre o $j$-ésimo e o $k$-ésimo QTLs;

$x_{i j}^{*}$ : é a variável indicadora do $j$-ésimo QTL que assume valores $1,0,-1$ para genótipos do QTL QQ, Qq e qq, respectivamente, multiplicados pelas probabilidades condicionais de os genótipos dos QTLs ocorrerem para os genótipos dos marcadores flanqueadores de um determinando intervalo;

$z_{i j}^{*}$ : é a variável indicadora do $j$-ésimo QTL que assume valores $-1 / 2,1 / 2 e-1 / 2$ para genótipos do QTL QQ, Qq e qq, respectivamente, multiplicados pelas probabilidades condicionais de os genótipos dos QTLs ocorrerem para os genótipos dos marcadores flanqueadores de um determinando intervalo;

$x_{i k}^{*}$ e $z_{i k}^{*}$ : possuem as mesmas definições de $x_{i j}^{*}$ e $z_{i j}^{*}$, respectivamente; 
$m$ : é o número de QTLs escolhidos com base em seus efeitos principais;

$t$ : é o número de efeitos epistáticos significativos entre pares de QTLs;

$e_{i}$ : é o erro aleatório associado à observação da $i$-ésima progênie.

Os arquivos do mapa genético gerado no Mapmaker versão 3.0, e os dados fenotípicos médios dos sete ambientes foram importados para o WinQTLCart. Neste programa utilizou-se o procedimento de análise MIM para população $F_{2}$, usando-se $o$ "default" deste procedimento para criar um modelo inicial de busca de QTLs. As análises foram realizadas a cada $1 \mathrm{cM}$ do mapa de ligação. A estatística para verificar a significância dos efeitos e a presença dos QTLs foi o teste da razão de verossimilhança; a seleção de modelo, incluindo ou excluindo os efeitos principais dos QTLs e de epistasia, foi feita com o uso da estatística de Critério de Informação Baysiano (Baysian Information Criterion - BIC), segundo a recomendação de Zeng et al. (1999).

A partir do modelo inicial e aceitando os "defaults" recomendados do programa, realizaram-se os seguintes passos:

$1^{\circ}$ - Otimização das posições para o modelo MIM;

$2^{\circ}$ - Busca de novos QTLs para o modelo MIM;

$3^{\circ}$ - Busca de novas epistasias para o modelo MIM;

$4^{\circ}$ - Teste para existência de QTLs do modelo;

$5^{\circ}$ - Teste para existência de epistasias do modelo;

Esses passos foram repetidos até não se encontrarem novos QTLs e epistasias. Finalizando-se o processo de análise, utilizaram-se os seguintes passos:

$1^{\circ}$ - Otimização das posições para o modelo MIM, novamente;

$2^{\circ}$ - "Testing All” para testar os efeitos de aditivos, dominância e epistasia;

$3^{\circ}$ - "Re-Estimate Model' para reestimar os parâmetros do modelo;

$4^{\circ}$ - "MIM Model Summary" para fornecer o resumo dos dados analisados e seus gráficos, finalizando o processo de análises. 


\subsection{Valores genotípicos preditos das progênies}

O programa WinQTLCart 2.0 fornece os valores genotípicos preditos, baseados nas informações de marcadores e nos efeitos estimados dos QTLs para cada progênie. Os valores genotípicos das progênies são efeitos probabilísticos, isto é, consideram-se as probabilidades dos genótipos dos QTLs, dada a observação de os genótipos dos marcadores estarem em uma determinada progênie (Zeng et al., 1999).

Os valores genotípicos preditos de cada progênie foram estimados, utilizando-se a expressão (Zeng, 1999):

$$
\hat{y}_{i}=\hat{\mu}+\sum_{j=1}^{3^{m}} \sum_{r=1}^{m+t} \hat{\pi}_{i j} D_{j r} \hat{E}_{r}
$$

em que:

$\hat{y}_{i}$ : é o valor genotípico estimado da $i$-ésima progênie;

$\hat{\mu}$ : é a média geral;

$m$ : é o número de QTLs com efeitos principais significativos;

$t$ : é o número de QTLs com efeitos epistáticos significativos;

$3^{m}$ : é o número possível de genótipos dos QTLs com efeitos significativos;

$\hat{\pi}_{i j}$ : é a probabilidade condicional de o QTL ter o genótipo $g$ dado os genótipos dos marcadores $M$ e valores fenotípicos $y$, isto é: $\hat{\pi}_{i j}=\operatorname{Pr} o b(g / M, y)$ para a $i$-ésima progênie e para o $j$-ésimo QTL;

$D_{j r}$ : é o $r$-ésimo elemento que compõe o vetor linha $D_{j}$ da matriz $\mathbf{D}$ que especifica as configurações das probabilidades condicionais dos efeitos principais (aditivo e dominanate) dos QTLs e dos efeitos epistáticos para o $j$-ésimo genótipo do QTL;

$\hat{E}_{r}$ : é a estimativa do $r$-ésimo elemento do vetor coluna $\mathbf{E}$, que contém os parâmetros dos efeitos principais dos QTLs e dos efeitos epistáticos.

Os valores genotípicos preditos de cada progênie foram obtidos pelo procedimento MIM do programa WinQTLCart 2.0 (Wang et al., 2004). Ressalta-se que os 
valores genotípicos preditos das progênies são probabilísticos, uma vez que são função da probabilidade $\hat{\pi}_{i j}$.

Estimou-se a correlação entre os valores genotípicos preditos e os valores fenotípicos médios das progênies. Utilizou-se os teste $t$ para verificar se a correlação diferiu de zero $(\rho \neq 0)$, segundo o procedimento descrito por Steel \& Torrie (1980). 


\section{RESULTADOS E DISCUSSÃO}

\subsection{Análises de variância e parâmetros genéticos}

Os testes de normalidade para os resíduos e para os valores do caráter apresentaram distribuição normal, indicadas pela não significância dos testes de normalidade de Shapiro-Wilk $(P \leq 0,01)$; por isso, não houve necessidade de transformação dos dados (Figuras 1 e 2). A verificação de homogeneidade das variâncias dos resíduos, pelo teste do $F$ máximo, não foi significativa $(P \leq 0,01)$. As variâncias mantiveram-se homogêneas, não havendo discrepância, sendo a razão da maior e menor variância do resíduo de 5,22 (Tabela $5)$.

O coeficiente de variação experimental (CV) da análise de variância conjunta foi de 11,59\% (Tabela 4), ocorrendo o menor CV no ambiente Anhembi, no ano agrícola 2002/2003 (5,44\%), e o maior no ambiente Genética, no ano agrícola 2003/2004 (14,22\%) (Tabela 5). Tais valores estão nos limites encontrados na literatura. Silva et al. (2004) e Lopes (2003), em seus trabalhos sobre herança da reação de resistência à Phaeosphaeria maydis avaliados por escalas diagramáticas de notas, obtiveram um coeficiente de variação de $15,20 \%$ e $9,59 \%$, respectivamente. Segundo este último autor, o valor encontrado por ele apresenta um adequado nível de precisão experimental, uma vez que a avaliação por meio de escala de notas pode estar sujeita a alta margem de erro.

$\mathrm{Na}$ análise de variância conjunta, foram detectadas diferenças altamente significativas para os efeitos de ambientes, as progênies e a interação progênies $\mathrm{x}$ ambientes $(P \leq 0,01)$. As significâncias para ambientes e progênies mostraram que ocorreram diferenças entre os ambientes e a presença de variabilidade genética no material, respectivamente em relação à reação $P$. maydis. A variabilidade genética encontrada é oriunda da divergência genética em relação à reação a doença das linhagens genitoras. A interação 
significativa para progênies $\mathrm{x}$ ambientes mostra que as progênies apresentaram um comportamento diferencial nos ambientes em que foram avaliadas (Tabela 4).

A média geral das notas de severidade aplicada aos sete ambientes foi de 4,40, a qual, de acordo com a escala diagramática de notas utilizada, representa uma infestação média do patógeno de 22,26\% da área total foliar (Tabela 4). Entre os ambientes as notas de médias de parcelas variaram de 2,60 (Genética 02/03) a 5,39 (Anhembi 02/03); esses valores representam uma infestação média do patógeno de $6,44 \%$ e $34,44 \%$, respectivamente (Tabela 5).

As notas médias das linhagens genitoras das progênies $F_{2: 3}$, utilizadas neste trabalho, L 14-04B e L 08-05F, foram de 5,28 e 2,00, respectivamente, diferindo significativamente $(P \leq 0,05)$. De acordo com tais médias, a linhagem L 14-04B apresentou uma infestação média do patógeno de 33\% da área total foliar, enquanto a linhagem L 0805F apresentou infestação média foliar de 3\%, caracterizando a resistência da linhagem L 0805F ao patógeno e a susceptibilidade da linhagem L 14-04B. Essa diferença entre as linhagens genitoras já era esperada, uma vez que tais linhagens eram sabidamente contrastantes quanto à resistência à Phaeosphaeria maydis, condição necessária para executar o mapeamento e a identificação de QTLs de resistência à doença. No entanto a média das progênies $\mathrm{F}_{2: 3}$ não diferiu da média da linhagem L 14-04B, uma vez que seus intervalos de confiança são sobrepostos (Tabela 4).

Progênies cujas médias estiveram fora do intervalo de confiança dos parentais, sendo superiores à média da linhagem genitora superior, ou inferiores à média da linhagem genitora inferior, foram consideradas progênies transgressivas significativas para susceptibilidade e resistência, respectivamente. Considerando a média de todos os ambientes, ocorreram progênies transgressivas apenas no sentido da susceptibilidade à $P$. maydis, o que pode ser verificado pela comparação entre o intervalo de variação médio de progênies em todos os ambientes e os intervalos de confiança das linhagens genitoras L 1404B e L 08-05F (Tabela 4). O limite inferior do intervalo de variação foi de 2,54, que é superior ao limite superior do intervalo de confiança da linhagem genitora resistente L 0805F (2,34), indicando que não houve segregação transgressiva no sentido da resistência. Por 
outro lado, o limite superior do intervalo de variação das progênies foi de 5,99 , sendo ele maior que o limite superior do intervalo de confiança do genitor susceptível L 14-04B (5,88), indicando que houve segregação transgressiva no sentido da susceptibilidade (Tabela 4).

No ano agrícola de 2002/2003, ocorreu diferença significativa entre as médias de notas entre todos os ambientes $(P \leq 0,05)$. A menor média foi de 2,60, para o ambiente Genética 02/03, e a maior foi de 5,39, para Anhembi 02/03, representando 6,44\% e 34,44\% de infestação média, respectivamente. A diferença entre esses ambientes foi de $28 \%$ de infestação, mostrando que o ambiente Anhembi $02 / 03$ foi mais propício ao desenvolvimento do patógeno nesse ano agrícola (Tabela 5). A diferença entre as médias dos ambientes Genética 02/03 e Anhembi 02/03 não pode ser devida apenas à diferença de umidade, pois, em ambos os ambientes, os experimentos foram irrigados. A irrigação pode favorecer o desenvolvimento do patógeno, mas, neste caso, provavelmente outros fatores edafoclimáticos como diferenças das temperaturas nos ambientes contribuíram para que o ambiente Anhembi 02/03 fosse mais propício ao desenvolvimento da Phaeosphaeria maydis, em comparação à Genética 02/03 e também em relação aos demais ambientes. Entretanto, ano agrícola $2003 / 2004$, não houve diferença significativa entre os ambientes $(P \leq 0,05) \mathrm{em}$ que as progênies foram avaliadas.

Ao observar os limites inferiores e superiores dos intervalos de variações das médias de notas de infestação das progênies, nos dois anos agrícolas, verificou-se que o menor valor $(1,47)$ ocorreu no ambiente Genética $02 / 03$ e o maior valor $(7,57)$, no ambiente Genética 03/04 (Tabela 5). A nota média de infestação, 1,47, indicou que a progênie continha, em média, sintoma da mancha de Phaeosphaeria maydis na área foliar abaixo de $1 \%$ e a nota média, 7,57 , indicou que a progênie apresentou infestação média acima de 70\%. As médias desses ambientes foram de 2,60 para Genética 02/03 e de 4,81 para Genética 03/04, valores significativamente diferentes $(P \leq 0,05)$. Ao comparar as médias dos locais entre anos distintos, percebeu-se um aumento de $6,71 \%$ de infestação do patógeno. A média de infestação, no ano agrícola de 2002/2003, foi 4,14 (19,42\% de infestação) e de 4,74, no ano agrícola de 2003/2004 (26,13\% de infestação). A diferença na 
média do caráter, ocorrida no mesmo local e em anos diferentes, pode estar relacionada ao efeito residual de inóculo que permaneceu nos restos culturais do campo, pois o patógeno é necrotrófico e os experimentos de 2003/2004 foram instalados nas mesmas áreas do ano anterior; além disso, efeitos climáticos diferenciados ocorreram entre esses anos.

Lopes (2003) comenta que o valor significativo encontrado para diferenças no efeito da interação genótipos $\mathrm{x}$ anos pode ser devido às diferenças na quantidade de inóculo e/ou nas raças das populações patogênicas presentes em cada um dos experimentos, uma vez que a avaliação foi realizada com incidência natural do patógeno. Neste trabalho, como discutido anteriormente, provavelmente as quantidades de inóculos e raças do patógeno, influenciados pelas diferenças climáticas de cada ambiente, promoveram o efeito significativo da interação progênies $\mathrm{x}$ ambientes e também as diferenças entre anos agrícolas. Tal efeito de interação conduz à necessidade de os estudos relacionados à $P$. maydis serem realizados em vários ambientes, para permitir discriminar adequadamente os genótipos quanto às raças dos patógenos.

A estimativa da variância de progênies foi de $\hat{\sigma}_{p}^{2}=0,37$ e a da interação progênies x ambientes foi de $\hat{\sigma}_{p a}^{2}=0,12$, ambas diferiram significativamente de zero $(P \leq 0,05)$. As estimativas das variâncias de progênies foram cerca de três vezes superiores à estimativa da variância da interação, mostrando que a variância da interação teve pequena participação na variação fenotípica (Tabela 6). Como a interação progênies x ambientes foi significativa na análise de variância conjunta, mas pequena em relação à variância de progênies, é provável que esta interação seja do tipo simples, e não complexo, pois as correlações genéticas entre os ambientes foram elevadas e significativas (Tabela 8). A interação simples facilita a seleção de material resistente, pois indica que não há inversões de comportamento entre as progênies em diferentes ambientes, permitindo que a seleção seja feita em apenas um ambiente, a saber, no ambiente em que a doença apresenta maior severidade. No ambiente Anhembi 02/03 e 03/04, as manchas causadas pelo fungo apresentaram-se maiores, com coloração mais escura e com maior agressividade do patógeno, possibilitando uma discriminação mais fácil das progênies que nos outros ambientes. Tal observação já havia sido feita em anos anteriores, quando foram conduzidos experimentos com a $P$. maydis 
(Prof. José Branco de Miranda Filho, comunicação pessoal), o que poderia estar ocorrendo em função de diferentes raças do patógeno. Mas, até o momento não há na literatura trabalhos a respeito da identificação de raças de $P$. maydis, até porque o seu isolamento laboratorial é extremamente difícil (Lopes, 2003).

Dessa forma, apesar dos elevados valores de correlação entre os ambientes, possibilitando a discriminação de genótipos em um único ambiente, a possibilidade de existirem diversas raças do patógeno leva à recomendação de realizar a seleção em diversos ambientes, a escolher em função de a doença apresentar maior severidade.

A estimativa do coeficiente de herdabilidade de médias de parcelas no sentido amplo foi alta $(91,37 \%)$, com intervalo de confiança $(P \leq 0,05)$ variando de 89,90 a $92,60 \%$ (Tabela 6). O valor elevado de herdabilidade deve-se, possivelmente, ao número de ambientes de avaliação (7) e ao número de repetições (2) por ambientes, os quais reduziram significativamente as variâncias da interação patógeno $\mathrm{x}$ ambiente e do resíduo, respectivamente. Estimativas de coeficientes de herdabilidade de médias de parcelas, no sentido amplo foram relatadas por Carson (2001), Silva (2002) e Lopes (2003), as quais variaram de $63,00 \%$ a $92,80 \%$, mostrando que a estimativa deste trabalho apresentou valor aproximado aos relatados por esses autores.

Os valores elevados dos coeficientes de herdabilidade indicam que os processos simples de seleção e/ou avaliação de linhagens, progênies ou híbridos em experimentos com poucas repetições, em locais onde a doença ocorre com maior severidade, podem ser utilizados, mesmo em condições de infestação natural do patógeno.

Todas as estimativas das correlações fenotípicas e genéticas entre os ambientes foram elevadas, positivas e altamente significativas $(P \leq 0,01)$, indicando que as progênies se comportaram, em sua maioria, da mesma forma em relação à reação à infestação do patógeno, nos diferentes ambientes avaliados. Já as correlações genéticas indicam que, provavelmente, as diferenças nas expressões dos genes nos diferentes ambientes não foram de grande magnitude. Os valores dos coeficientes de correlação fenotípicas variaram de 0,54 (Anhembi 02/03 vs. Areão 02/03) a 0,77 (Genética 03/04 vs. Caterpillar 02/03 e Caterpillar 03/04 vs. Genética 03/04), e os coeficientes de correlações genéticas variaram de 0,67 
(Anhembi 02/03 vs. Genética 02/03) a 1,04 (Genética 03/04 vs. Areão 02/03). Notifica-se que as correlações genéticas foram superiores às correlações fenotípicas (Tabelas 7 e 8).

As correlações ambientais entre todos os ambientes não diferiram significativamente de zero (Tabela 9). Tais resultados sugerem que as populações do patógeno não devem diferir quanto à sua variabilidade, isto é, quanto à presença de diferentes raças. Dessa forma, as diferenças de incidências da doença, nos ambientes de avaliação, devem ser devidas às diferenças de temperatura e de umidade.

A correlação fenotípica é provocada pelos efeitos genéticos e ambientais (Vencovsky \& Barriga, 1992). A correlação ambiental não diferiu de zero, evidenciando que a correlação fenotípica é influenciada, basicamente, pela correlação genética. Os valores elevados das correlações fenotípicas não eram esperados, pois obteve-se um efeito de interação altamente significativo, indicando um comportamento diferencial das progênies nos ambientes. Uma possível explicação para esse comportamento pode ser o fato de que a correlação genética pode ser causada por efeitos pleiotrópicos dos genes, ou por falta de equilíbrio de ligação; neste último caso, o comportamento será transitório, manifestando-se nas primeiras gerações de populações obtidas por intercruzamento de genitores geneticamente divergentes (Vencovsky \& Barriga, 1992). Nesta pesquisa, a população utilizada é uma $\mathrm{F}_{2: 3}$, que explora o máximo de desequilíbrio de ligação, obtida com o cruzamento entre materiais divergentes para o caráter de interesse, visando ao mapeamento de QTLs. Talvez este fato seja o causador das altas correlações genéticas e fenotípicas entre os ambientes.

\subsection{Mapeamento de QTLs}

As 143 marcas microssatélites polimórficas, utilizadas para mapear a população $\mathrm{F}_{2}$, distribuíram-se em dez grupos de ligação. O comprimento do genoma foi estimado em 1.844,80 cM, com espaçamento médio entre marcas de $13 \mathrm{cM}$. O comprimento dos cromossomos variou de 112,22 cM (cromossomo 9) a 264,50 cM (cromossomo 1), e o número de marcas em cada cromossomo variou de 9 (cromossomo 7) a 21 (cromossomo 2) (Figuras 3 e 4). As marcas apresentaram-se bem distribuídas por todo o genoma. Apenas 
duas regiões apresentaram distâncias relativamente grandes entre marcadores: no braço longo do cromossomo 2, com distância de $65,70 \mathrm{cM}$ e no braço curto do cromossomo 4, com distância de 52,60 cM (Figuras 3 e 4).

Sibov et al. (2003) mapearam a mesma população deste trabalho, utilizando 117 marcadores microssatélites; os autores obtiveram um mapa com comprimento total de 1.634,00 cM e distância média entre marcas de 14 cM. Mangolin et al. (2004) utilizando 75 marcadores microssatélites, para mapear uma população de milho de clima tropical, obtiveram um mapa de 1.438,60 cM de comprimento total e com 19,18 cM de distância média entre marcas. Estes autores relatam que mapas similares de milho de clima tropical foram encontrados por Ribaut et al. (1996) e Jiang et al. (1999). Lopes (2003), em seu trabalho de mapeamento de reação de resistência à $P$. maydis, em população de milho de clima tropical, utilizou 81 marcas microssatélites e AFLPs, obtendo um mapa com comprimento total de $1.156,72 \mathrm{cM}$ e com $14,28 \mathrm{cM}$ de distância média entre marcas. Todos esses trabalhos obtiveram comprimentos de mapas genéticos menores do que os do presente trabalho, mais próximos dos obtidos por Sibov et al. (2003). Já a distância média entre as marcas deste trabalho aproximou-se dos valores apontados na literatura citada acima, com exceção de Mangolin et al. (2004), que obtiveram uma maior distância média entre marcas.

Foram mapeados seis QTLs de reação de resistência à Phaeosphaeria maydis, designados de $\mathrm{Ph} 1, \mathrm{Ph3}, \mathrm{Ph4}, \mathrm{Ph6}, \mathrm{Ph8a}$ e Ph8b. O termo $\mathrm{Ph}$ é referente às letras iniciais de Phaeosphaeria maydis; o número relaciona-se ao cromossomo em que se encontra o QTL e as letras $a$ e $b$ foram introduzidas para diferenciar os dois QTLs do cromossomo 8. A identificação gráfica desses QTLs pode ser visualizada pelos picos das curvas que os identificam e localizam (Figuras 3 a 7).

Os QTLs Ph3 e Ph6 apresentaram ação gênica aditiva (A), sendo nulo o efeito de dominância para o QTL Ph3. Os QTLs Ph1, Ph4, Ph8a e Ph8b apresentaram a ação gênica de dominância parcial (DP). Os efeitos aditivos dos QTLs encontrados variaram de -0,18 (Ph8b) a -0,31 (Ph8a), já os efeitos de dominantes, de 0,17 (Ph1) a 0,09 (Ph4). Os tipos de ações gênicas variaram de aditivo $(|d| /|a|=0, P h 3)$ ao tipo de dominância parcial $(|d| /|a|=0,70$, 
Ph1), com grau médio de dominância de $|d| /|a|=0,32$, ou seja, dominância parcial do caráter. As porcentagens de variação fenotípica explicada por cada QTL variaram de $R^{2}=2,91 \%$ (Ph8b) a $R^{2}=11,86 \%(P h 8 a)$ e a variação explicada pelo conjunto de QTLs mapeados foi de $R^{2}=41,62 \%$. Detectou-se, também, epistasia do tipo dominante x dominante entre os QTLs Ph8a e Ph8b, com $R^{2}=3,41 \%$ explicando a variação fenotípica (Tabela 10).

O QTL Ph1 localiza-se no braço curto do cromossomo 1, a 65,11 cM de distância da primeira marca do cromossomo, com efeito aditivo de $-0,25$, dominante de 0,17 e grau de dominância de 0,70 , indicando ação gênica do tipo dominância parcial, que é explicado por 5,77\% da variação fenotípica. O QTL Ph3 localiza-se no braço longo do cromossomo 3, na posição de 139,60 cM de distância da marca inicial, apresenta somente efeito aditivo de 0,25, sendo explicado por 5,77\% da variação fenotípica. O QTL Ph4 localiza-se no braço longo do cromossomo 4, na posição de 126,07 cM de distância da primeira marca, com efeito aditivo de $-0,30$, dominante de 0,09 e grau de dominância de 0,31, indicando ação gênica do tipo de dominância parcial, que é explicado por 6,49\% da variação fenotípica. O QTL Ph6 localiza-se no braço longo do cromossomo 6, na posição de 157,80 cM de distância da marca inicial, com efeito aditivo de -0,20, dominância de $-0,04$ e grau de dominância de 0,18, indicando ação gênica do tipo aditiva, que é explicado por 5,40\% da variação fenotípica. O QTL Ph8a localiza-se no braço curto do cromossomo 8, na posição de 21,87 cM de distância da primeira marca, possui efeito aditivo de -0,31, dominante de 0,09, grau de dominância de 0,29, que representa ação gênica do tipo dominância parcial, que é explicado por $11,86 \%$ da variância fenotípica. Nesse mesmo cromossomo 8 , detectouse o QTL Ph8b, no braço longo e na posição de 131,14 cM da marca inicial, possui efeito aditivo de $-0,18$, dominante de $-0,11$, grau de dominância de 0,62 , que representa ação gênica do tipo dominância parcial e que é explicado por $2,91 \%$ da variação fenotípica. Um efeito de epistasia foi detectado entre os QTLs Ph8a e Ph8b, localizados a 21,87 cM e 131,14 cM, respectivamente da marca inicial, apresentaram efeito dominante $\mathrm{x}$ dominante de 0,56 , que é explicado por 3,41\% da variação fenotípica. Note-se que a epistasia encontrada no cromossomo 8, entre os QTLs Ph8a e Ph8b, foram mapeados separadamente por 109,27 cM, indicando que estes QTLs não estão ligados. Juntos, contribuíram pelos seus efeitos 
aditivos, de dominância e de epistasia com 18,18\% da variância fenotípica, sendo este cromossomo responsável pelos maiores efeitos de resistência genética à $P$. maydis encontrados neste trabalho (Figura 4 e Tabela 10).

Em módulo, os efeitos genéticos aditivos foram maiores que os efeitos de dominância para todos os QTLs, sendo aqueles, em média, três vezes maiores que estes. Os sinais negativos dos efeitos aditivos indicam que os alelos da linhagem L 08-05F, que possui a menor média, diminuem o valor do caráter. Como a avaliação foi realizada por meio de escala de notas, sendo a menor nota indicadora da maior resistência, a diminuição no valor do caráter leva à resistência à doença. Portanto, o aumento da resistência foi conferido pelos alelos da linhagem L 08-05F, para todos os QTLs (Tabela 10).

As estimativas dos efeitos de dominância dos QTLs Ph1 e Ph4 foram positivas, mas baixas, enquanto as estimativas desses efeitos foram negativas para os QTLs Ph6, Ph8a e Ph8b e nula para Ph3. Estimativas positivas do efeito genético dominante indicaram que os genótipos heterozigóticos possuem, em média, valor fenotípico superior à média dos genótipos homozigóticos dominantes e recessivos e, de modo análogo, estimativas negativas de efeitos de dominância indicaram que o heterozigoto possui valor fenotípico inferior à média dos homozigotos dominantes e recessivos. Como discutido anteriormente, neste caso, o valor negativo é o de interesse, por conferir resistência à $P$. maydis. As presenças de valores de dominância negativos de alguns QTLs (Ph6, Ph8a e Ph8b) mostraram que alelos da linhagem L 08-05F agiram de forma complementar aos alelos da linhagem L 14-04B a favor da resistência à $P$. maydis.

Trabalhos utilizando médias de gerações e análises dialélicos corroboram, em sua maior parte, com os resultados deste trabalho. Paterniani et al. (2000) avaliaram híbridos simples de milho, de cruzamentos dialélicos de linhagens endogâmicas, para a reação à Phaeosphaeria maydis e à Puccinia Polysora, utilizando escala diagramática de notas de 1 a 9 e avaliando 30 dias após o florescimento. Os resultados para a doença P. maydis apresentaram CEC e CGC significativos, mas a magnitude da CGC indicou que os efeitos aditivos foram mais importantes que os dominantes no controle da doença, explicando os efeitos aditivos $94 \%$ da variação total; os efeitos dominantes contribuíram com $6 \%$ da variação total. 
Pegoraro et al. (2002) estudaram a herança da reação à $P$. maydis de linhagens de milho, utilizando análise dialélica e médias de gerações, com avaliação feita após 30 dias do florescimento e inferindo sobre a média da porcentagem da área foliar afetada pela $P$. maydis na parcela. As análises dialélicas indicaram significância na CGC e CEC, sendo de maior importância os efeitos de aditividade (CGC) sobre os efeitos de dominância (CEC); verificaram também a presença de efeitos epistáticos. Os autores comentam que assumiram, conforme indicado pela análise da média de gerações, a presença de ação de dominância parcial e epistasia. Os valores estimados de herdabilidade foram elevados, sugerindo a obtenção de ganhos genéticos com a seleção fenotípica de indivíduos resistentes em gerações segregantes. Concluíram pelas freqüências dos indivíduos $F_{2}$ à presença de três genes maiores governando o caráter de resistência à $P$. maydis, com a presença de outros genes de menores efeitos.

Silva (2002) e, posteriormente, Silva et al. (2004) estudaram a análise dialélica da reação de resistência à $P$. maydis em linhagens endogâmicas susceptíveis, moderadamente resistentes e resistentes. Avaliaram a planta inteira (PI) e a severidade da doença na folha posicionada abaixo do ponto de inserção da espiga principal (AFA), após 30 dias do florescimento, e com base em escala diagramática de notas de 1 a 9. Os efeitos de CGC foram significativos enquanto os de CEC foram não significativos para os dois tipos de avaliação, evidenciando que os efeitos genéticos aditivos são mais importantes, como fonte de variação, para a reação de resistência à doença. Nesse mesmo trabalho, Silva (2002) avaliou linhagens susceptíveis, em cruzamento com linhagens resistentes, utilizando análise de médias de gerações. Esse estudo de herança da reação de resistência à $P$. maydis também indicou a maior importância do efeito genético aditivo sobre os efeitos de dominância, contabilizando os efeitos genéticos dominantes, em média, menos de 10\% da variação entre as médias de gerações. As estimativas da herdabilidade, no sentido amplo, foram altas, variando de 82,10 a $92,80 \%$ para PI e 63,40 a $77,80 \%$ para AFA. Estimaram três genes envolvidos na reação de resistência à $P$. maydis.

Lopes (2003) utilizou a análise de média de gerações de duas populações, para estudar a herança da reação de resistência à $P$. maydis em linhagens tropicais de milho. $\mathrm{O}$ 
material utilizado e a avaliação foram os mesmos que os utilizados por Silva (2002). O autor comenta que os efeitos genéticos aditivos foram mais importantes na determinação do caráter de resistência, com participação menor dos efeitos dominantes para as duas populações estudadas, representando os efeitos aditivos $20,52 \%$ e $12,83 \%$ e os efeitos de dominância, 3,04\% e 10,92\% da variação total, respectivamente, para cada população analisada. Suas estimativas de herdabilidade, no sentido amplo, foram altas (63 e 71\%).

Trabalhando com linhagens endogâmicas de clima temperado, Carson (2001) estudou a herança da reação de resistência à $P$. maydis, utilizando análise de média de gerações e avaliação por escala diagramática de notas de 0 a 9 , no estádio de grão na forma de dente. Foi constatada significância dos efeitos genéticos de aditividade e de dominância, sendo os efeitos genéticos aditivos superiores aos efeitos de dominância. Os efeitos de dominância contribuíram com apenas $10 \%$ da variação entre as médias de gerações, e as estimativas da herdabilidade foram altas, tanto no sentido amplo (85\%), como no sentido restrito $(70 \%)$. O autor também comenta que não houve evidência de epistasia, ao analisar seus dados.

Os trabalhos de Paterniani et al. (2000), Pegoraro et al. (2002), Silva (2002), Lopes (2003), Carson (2001) e Silva et al. (2004) estão em concordância com este trabalho, ao afirmar que os efeitos genéticos de aditividade foram os mais importantes na determinação da reação de resistência à $P$. maydis, em relação aos efeitos genéticos de dominância, contribuindo com o elevado valor de herdabilidade. Além dessas afirmações, Pegoraro et al. (2002) relatam a presença de epistasia e de dominância parcial em seu trabalho, cujos resultados convergem com os deste. Já Carson (2001) divergiu, ao afirmar que não encontrou evidência de epistasia em seu trabalho de análise de média de gerações. $\mathrm{O}$ resultado a respeito da ação gênica envolvida no controle da reação a resistência à $P$. maydis, encontrado no presente estudo diverge do obtido no trabalho relatado por Das et al. (1989a): estes autores encontraram efeitos significativos da CEC e CGC em análise de cruzamentos dialélicos, envolvendo variedades de polinização aberta de milho, com os efeitos genéticos dominantes como o principal componente genético em relação aos efeitos aditivos. Posteriormente, Das et al. (1989b) analisaram, em cruzamentos dialélicos, 
variedades de polinização aberta diferentes do trabalho anterior e constataram os mesmos resultados obtidos anteriormente.

Poucos trabalhos foram encontrados sobre o mapeamento de QTLs para a reação de resistência à $P$. maydis, principalmente relacionados a materiais de clima tropical. Lopes (2003) realizou um estudo de mapeamento de QTLs de reação de resistência à P. maydis no cruzamento de duas linhagens de clima tropical. Progênies da geração $\mathrm{F}_{2}$ foram genotipadas por marcadores microssatélites e AFLP; e pela metodologia de mapeamento por intervalo composto (CIM), foram mapeados um QTL nos cromossomos 1, 2 e 5 e dois QTLs no cromossomo 4, tendo concordância com os resultados deste trabalho os QTLs localizados nos cromossomos 1 (bin 1.03) e 4 (bin 4.08) (Tabela 10). Houve concordância de resultados dos efeitos genéticos, indicando a maior importância dos efeitos de aditividade sobre os efeitos de dominância. A proporção da variação fenotípica explicada por cada QTL foi mais alta $(9,81$ a $32,87 \%)$ do que a encontrada no mapeamento em estudo (3,41 a 11,86\%).

Em material de clima temperado, Carson et al. (1996) mapearam QTLs de reação de resistência à $P$. maydis, em linhagens puras recombinantes do cruzamento dos materiais B73 e Mo17. As linhagens puras recombinantes foram genotipadas por marcadores RFLP, por isoenzimas e por microssatélites; pela análise de regressão de marcas simples, foram identificados QTLs no braço curto do cromossomo 7 e no braço longo dos cromossomos 8 e 10, mostrando concordância com os resultados do presente trabalho apenas o QTL encontrado no braço longo do cromossomo 8. A porcentagem de variação fenotípica, explicada pelo conjunto de QTLs mapeados (23\%), ficou abaixo do encontrado (41,62\%). Posteriormente, Carson et al. (2004) realizaram um estudo de mapeamento de QTLs do cruzamento dos mesmos parentais. Pela análise de mapeamento por intervalo composto (CIM), foram identificados cinco QTLs em três diferentes cromossomos; os autores relatam que os efeitos genéticos aditivos foram superiores aos efeitos de dominância, com uma interação aditivo $\mathrm{x}$ aditivo e a presença de alta herdabilidade do caráter. Tal trabalho corrobora com este, a respeito da maior importância dos efeitos genéticos aditivos em relação aos efeitos genéticos dominantes, contribuindo com alta herdabilidade. No entanto, 
$\mathrm{o}$ efeito de interação aditivo $\mathrm{x}$ aditivo diverge da interação encontrada de dominante $\mathrm{x}$ dominante.

É importante salientar que a metodologia MIM empregada apresenta um poder de identificação e de precisão maior, por considerar os efeitos de interação entre QTLs, quando comparada com outras metodologias como Composite Interval Mapping (CIM) e o Interval Mapping (IM) (Zeng et al., 1999).

\subsection{Comparações entre seleção assistida e com médias de progênies}

Os valores genotípicos preditos das progênies avaliadas variaram de 3,37 a 5,29, enquanto os valores fenotípicos médios variaram de 2,54 a 5,99, com média geral de 4,40. A correlação entre os valores preditos e os fenotípicos médios foi positiva e altamente significativa $(P \leq 0,01)$, embora de magnitude não muito elevada, isto é, $r=0,70$. Portanto o valor do coeficiente de determinação $\left(R^{2}=r^{2}\right)$ é de $49 \%$, mostrando que $49 \%$ da variação dos valores fenotípicos médios é explicado pela variação dos valores genotípicos preditos.

O valor do coeficiente de determinação indica que apenas parte das progênies selecionadas, com base nos valores fenotípicos médios e valores genotípicos preditos, serão coincidentes. Com efeito, aplicando-se intensidades de seleção de 10\% (26 progênies selecionadas) e de 5\% (13 progênies selecionadas), apenas 12 e 6 progênies foram selecionadas pelos dois procedimentos, isto é, uma coincidência de 46,15\%.

As médias de progênies selecionadas pelos valores fenotípicos médios e preditos foram de 3,06 e 3,55 e de 3,22 e 3,68 para intensidades de seleção de 5\% e de 10\%, respectivamente. Os diferenciais de seleção (ds) foram de $-1,35$ e $-1,18$ e de $-0,85$ e - -0,73 para a seleção com base nas médias fenotípicas e valores preditos e para 5\% e 10\% de intensidades de seleção, respectivamente. Os desvios entre as médias fenotípicas $(\mathrm{M})$ e os valores preditos $(\mathrm{P})$ das progênies selecionadas com base nos valores fenotípicos (M-P) variaram de $-1,11$ a $-0,28$ e de $-1,19$ a 0,01 , enquanto, para as progênies selecionadas com base nos valores preditos os desvios (P-M) variaram de $-1,09$ a 0,88 e de $-1,17$ a 0,88 para intensidades de seleção de 5\% e 10\%, respectivamente. A maioria dos desvios (M-P) foi negativa $(96,15 \%)$, com apenas um valor positivo, enquanto a maioria dos desvios (P-M) foi 
positiva $(61,54 \%)$, mostrando que os valores preditos foram, na grande maioria, superiores aos valores fenotípicos médios (Tabela 11).

Como a seleção de progênies ocorreu no sentido de reduzir a intensidade da doença, isto é, são selecionadas progênies com menores valores fenotípicos médios e com menores valores preditos, os diferenciais de seleção são negativos. Observa-se que os diferenciais de seleção, para os valores fenotípicos médios, foram inferiores aos da seleção com os valores preditos. As respostas à seleção com base nos valores fenotípicos $\left(R s=d s \times h^{2}\right)$ são de $-1,08$ e de $-1,23$, que correspondem a $-24,55 \%$ e $-27,95 \%$ de redução da intensidade da doença, para intensidades de seleção de $10 \%$ e 5\%, respectivamente. Para a seleção com base nos valores preditos, a resposta à seleção pode ser estimada por $R s=d s \times R^{2}$, uma vez que o $R^{2}$ corresponde à variância dos efeitos genotípicos dos QTLs, dividida pela variância fenotípica e correspondente ao coeficiente de herdabilidade (Kao et al., 1999). As estimativas das respostas à seleção foram de $-0,30$ e de $-0,35$, que correspondem a - $6,82 \%$ e $-8,04 \%$ de redução da severidade da doença, para intensidades de seleção de $10 \%$ e $5 \%$, respectivamente.

Tais resultados mostram que a seleção baseada nos valores fenotípicos médios é cerca de 3,5 vezes mais eficiente que a seleção praticada com os valores preditos. Deve ser ressaltado, entretanto, que as respostas à seleção foram estimadas com base em coeficientes de herdabilidade no sentido amplo e, portanto, além da variância genética aditiva contêm também variância dominante e epistática. Assim, ao se recombinarem as progênies, as respostas à seleção devem ser inferiores àquelas estimadas. As médias esperadas das populações após seleção $\left(\mu_{P M}=\mu_{P o p}+R s\right)$ seriam de 3,32 e 3,17, e de 4,10 e 4,05, para a seleção com base nos valores fenotípicos médios e com base nos valores preditos, para a seleção com intensidades de $10 \%$ e 5\%, respectivamente. Ressalta-se, novamente, que estes valores estão superestimados por se utilizarem coeficientes de herdabilidade no sentido amplo.

A superioridade da seleção com base nos valores fenotípicos médios pode ser devida ao fato de a estimativa do coeficiente do herdabilidade ser muito alta (91,37\%), a qual deve ser resultante do número de ambientes (7) e do número de repetições por ambiente 
(2), o que deve ter reduzido consideravelmente a estimativa da variância da interação genótipo x ambiente $\left(\sigma_{p a}^{2} / 7\right)$ e do erro experimental $\left(\sigma^{2} / 14\right)$.

Os valores genotípicos preditos das progênies são obtidos considerando-se os efeitos gênicos dos QTLs, as probabilidades de QTLs estarem presentes nas progênies e os valores fenotípicos destas. Tais valores são, portanto, índices de seleção, pois consideram, simultaneamente, os valores genotípicos dos QTLs e os valores fenotípicos das progênies (Kao et al., 1999; Zeng et al., 1999). Devido a isso, espera-se, a priori, que a seleção baseada neste índice seletivo seja superior à seleção baseada nas médias dos valores fenotípicos. Entretanto isso só poderia ocorrer, se fossem mapeados a maior parte dos QTLs que controlam o caráter, o que não ocorreu neste trabalho, uma vez que o $R^{2}$ foi de apenas $41,62 \%$. Isso pode ter ocorrido pelo fato de, em algumas regiões, o mapa genético ter apresentado grandes distâncias entre marcadores adjacentes, que reduzem o poder de detectar e mapear QTLs nessas regiões. Além disso, as análises estatístico-genéticas disponíveis para o mapeamento de QTLs provavelmente não conseguem localizar QTLs com efeitos muitos pequenos, isto é, que contribuam individualmente muito pouco para a variação genética.

Entretanto deve-se ressaltar que a eficiência real de um procedimento de seleção sobre o outro só poderá ser aferida após a seleção das progênies superiores, as recombinações das mesmas e as posteriores avaliações das populações melhoradas, em experimentos com repetições das seleções praticadas pelos dois procedimentos.

\subsection{Considerações finais}

Um programa de melhoramento, para ser conduzido de forma adequada, necessita de informações sobre as heranças dos caracteres que serão submetidos à seleção. Neste trabalho, foi investigada a herança da reação à mancha de Phaeosphaeria causada pelo fungo Phaeosphaeria maydis. Até alguns anos atrás, a doença não era considerada importante, pois ocorrendo no final do ciclo do milho, não ocasionava perdas significativas, além de apresentar ocorrência esporádica. Nos últimos anos, entretanto, a doença começou a aparecer antes ou durante o florescimento, e a sua ocorrência aumentou, causando prejuízos 
significativos. Devido à sua pouca importância no passado, poucos trabalhos foram conduzidos, visando a determinar a herança da reação de genótipos de milho à infecção por P. maydis.

Neste trabalho, os resultados mostraram que a reação à $P$. maydis apresentou coeficiente de herdabilidade elevado e baixa interação de genótipo por ambiente, mostrando que processos simples de seleção, como a seleção fenotípica individual, podem acarretar progressos substanciais com seleção. Foram mapeados seis QTLs em cinco cromossomos, os quais explicaram, em conjunto, $41,62 \%$ da variância fenotípica; o grau médio de dominância foi de dominância parcial. Os resultados reportados na literatura, oriundos de análises de cruzamentos dialélicos e de médias de gerações, mostraram, em sua maioria, que os efeitos aditivos são mais importantes que os efeitos não aditivos (dominância e epistasia) e que o caráter apresenta herdabilidade alta, o que está de acordo com os resultados obtidos neste trabalho.

Apenas três trabalhos com mapeamento de QTLs para reação à $P$. maydis foram reportados, sendo dois com germoplasma de clima temperado e um tropical. Carson et al. (1996) reportaram o mapeamento de quatro QTLs, localizando-se um deles no braço longo do cromossomo 8, região onde foi mapeado um dos QTLs deste trabalho. Carson et al. (2004) relataram o mapeamento de cinco QTLs para este caráter, mas não apresentaram epistasia as posições dos mesmos. Lopes (2003) reportou o mapeamento de cinco QTLs, em germoplasma tropical, sendo dois destes QTLs mapeados nos bins 1.03 (braço curto do cromossomo 1) e 4.07-4.08 (braço longo do cromossomo 4), também mapeados neste trabalho. O mapeamento de QTLs pode variar entre as populações utilizadas, pois devem estar segregando para serem detectados. Assim, com os resultados reportados e os deste trabalho, apenas dois QTLs são coincidentes, ambos de germoplasma tropical; provavelmente um QTL descrito por Carson et al. (1996) também foi mapeado neste trabalho.

O mapeamento de QTLs permitiu acrescentar informações sobre a herança da reação à $P$. maydis, pois mostrou regiões cromossômicas onde estão localizados QTLs que afetam o caráter e os efeitos gênicos deste. Tais informações podem ser utilizadas em 
programas de melhoramento, visando a aumentar a eficiência destes. A seleção de progênies, baseando-se nos valores preditos delas e em informações oriundas dos efeitos dos QTLs, mostrou-se pouco eficiente, quando comparada à seleção baseada nos valores fenotípicos médios. Entretanto a comparação real dos dois procedimentos só poderia ser aferida após a seleção e a avaliação em experimentos com repetições das populações melhoradas. De qualquer forma, como o coeficiente de herdabilidade do caráter foi muito elevado e superior ao coeficiente de determinação referente aos QTLs, a seleção com base nos valores fenotípicos médios das progênies deve ser mais eficiente que a seleção com base nos valores preditos.

Como comentado anteriormente, a reação ao patógeno $P$. maydis é um caráter de alta herdabilidade e, portanto, processos simples de seleção, como a seleção fenotípica individual, devem apresentar respostas à seleção que permitem a seleção de genótipos com alto nível de resistência a este patógeno. Entretanto, alguns problemas deste procedimento devem ser apontados: (I) um ciclo de seleção necessita de duas gerações, uma vez que só pode ser praticada após o florescimento; (II) genótipos transgressivos para resistência são raros, como mostraram os resultados deste trabalho; (III) em programas de melhoramento, só são utilizados cruzamentos de linhagens elites e, portanto, alelos favoráveis, oriundos de materiais não elites, podem não ser utilizados; (IV) a seleção só pode ser praticada em locais onde a doença ocorre com alto nível de severidade para permitir que a seleção seja efetiva. $O$ uso de marcadores moleculares pode auxiliar nos programas de melhoramento, pois: (I) genótipos com alelos favoráveis podem ser identificados antes do florescimento; (II) QTLs com alelos favoráveis podem ser identificados em genótipos elites e não elites; (III) a seleção pode ser praticada na ausência do patógeno; (IV) os alelos favoráveis dos QTLs podem ser transferidos para linhagens elites utilizando-se retrocruzamentos assistidos por marcadores moleculares, como reportado por Stuber et al. (1992b), Bouchez et al. (2002) e Benchimol (2002).

Finalmente, é preciso relatar o trabalho de McMullen \& Simcox (1995a, b). Para esses autores, os locos que afetam a reação de plantas de milho às diferentes doenças não estão distribuídos ao acaso no genoma do milho, mas agrupados em algumas regiões 
cromossômicas. Os autores relatam QTLs de reação a diversas doenças nos dez cromossomos, mas agrupados em regiões distintas. Por exemplo, QTL para reações às doenças de cercosporiose (Cercospora zea-maydis), vírus da listra do milho (etiologia desconhecida) e podridão por Erwinia (Erwinia stewartii) foram mapeados nos bins 1.04, 1.04, 1.05 , respectivamente. Isso sugere que compostos fitoquímicos que acarretam reações aos diferentes patógenos podem ser produzidos pelos mesmos QTLs.

Comparando-se os QTLs mapeados neste trabalho com aqueles relatados por McMullen \& Simcox (1995a, b), foram encontradas as seguintes correspondências com QTLs mapeados para outras doenças: QTL Ph1 (bin 1.03) próximo ao QTL para reação ao vírus da listra do milho (Maize Streak Virus - MSV) (bin 1.04) e para a podridão por Erwinia (Erwinia stewartic) (bin 1.04). O QTL Ph3 (bins 3.07-3.08) próximo ao QTL para podridão do colmo (Giberella zea (Schwein.) Petch) (bin 3.06) e à doença causada pela mancha de Helminthosporium turcicum (Setosphaeria turcica) (bin 3.07-3.08). O QTL Ph4 (bin 4.08) próximo ao QTL para podridão por Erwinia (Erwinia stewartii) (bin 4.07), à cercosporiose (Cercospora zea-maydis) (bin 4.07 e 4.08) e à antracnose do colmo (Colletotrichum graminicola (Ces.) Wils.) (bin 4.08). O QTL Pb6 (bins 6.06-6.07) próximo ao QTL para podridão por Erwinia (Erwinia stewartii) (bin 6.04). O QTL Ph8a (bins 8.00-8.02) próximo ao QTL à mancha de Helminthosporium turcicum (Setosphaeria turcica) (bin 8.03-8.04) e o QTL Ph8b (bins 8.06-8.07) próximo ao QTL para reação à cercosporiose (Cercospora z̧ea-maydis) (bin 8.05) e à mancha de Helminthosporium turcicum (Setosphaeria turcica) (bin 8.06). Esses dados mostram que a hipótese apresentada pelos autores pode estar correta, sugerindo que genótipos resistentes/tolerantes a um patógeno poderiam apresentar a mesma reação a outros patógenos.

Apesar de não terem sido avaliadas reações a outros patógenos, a linhagem L 1404B, susceptível à P. maydis, apresentou, também, sintomas de susceptibilidade a diversas outras doenças, como a helmintosporiose e a cercosporiose, enquanto a linhagem L 08-05F, resistente à $P$. maydis, não apresentou sintomas dessas doenças, por ocasião da avaliação, ou seja, 30 dias após o florescimento. Entretanto, para suportar essa hipótese, seria necessário mapear QTLs das mesmas populações para os diferentes patógenos. É possível, como 
mostraram McMullen \& Simcox (1995a, b), que existam diversos QTLs que conferem resistência/susceptibilidade a diversas doenças, simultaneamente, mas é provável que existam QTLs específicos para a reação às mesmas doenças. 


\section{CONCLUSÕES}

Os resultados obtidos neste trabalho sugerem que:

1. Parte dos QTLs que controlam a reação de resistência/susceptibilidade de genótipos de milho à Phaeosphaeria maydis (P. Henn.) foram mapeados, uma vez que explicaram abaixo de $50 \%$ da variância fenotípica;

2. Os seis QTLs mapeados estão localizados nos cromossomos 1 (Ph1), 3 (Ph3), 4 (Ph4), 6 (Ph6) e 8 (Ph8a e Ph8b), e apresentaram dominância parcial como grau médio de dominância;

3. A seleção de progênies com base nos valores fenotípicos médios mostrouse superior à seleção baseada nos valores preditos das progênies com os efeitos dos QTLs, devido ao elevado coeficiente de herdabilidade do caráter;

4. Dos QTLs mapeados apenas dois foram mapeados em outras pesquisas relatadas na literatura;

5. Todos os QTLs mapeados encontram-se próximos a QTLs mapeados para reações a outros patógenos. 
ANEXOS 


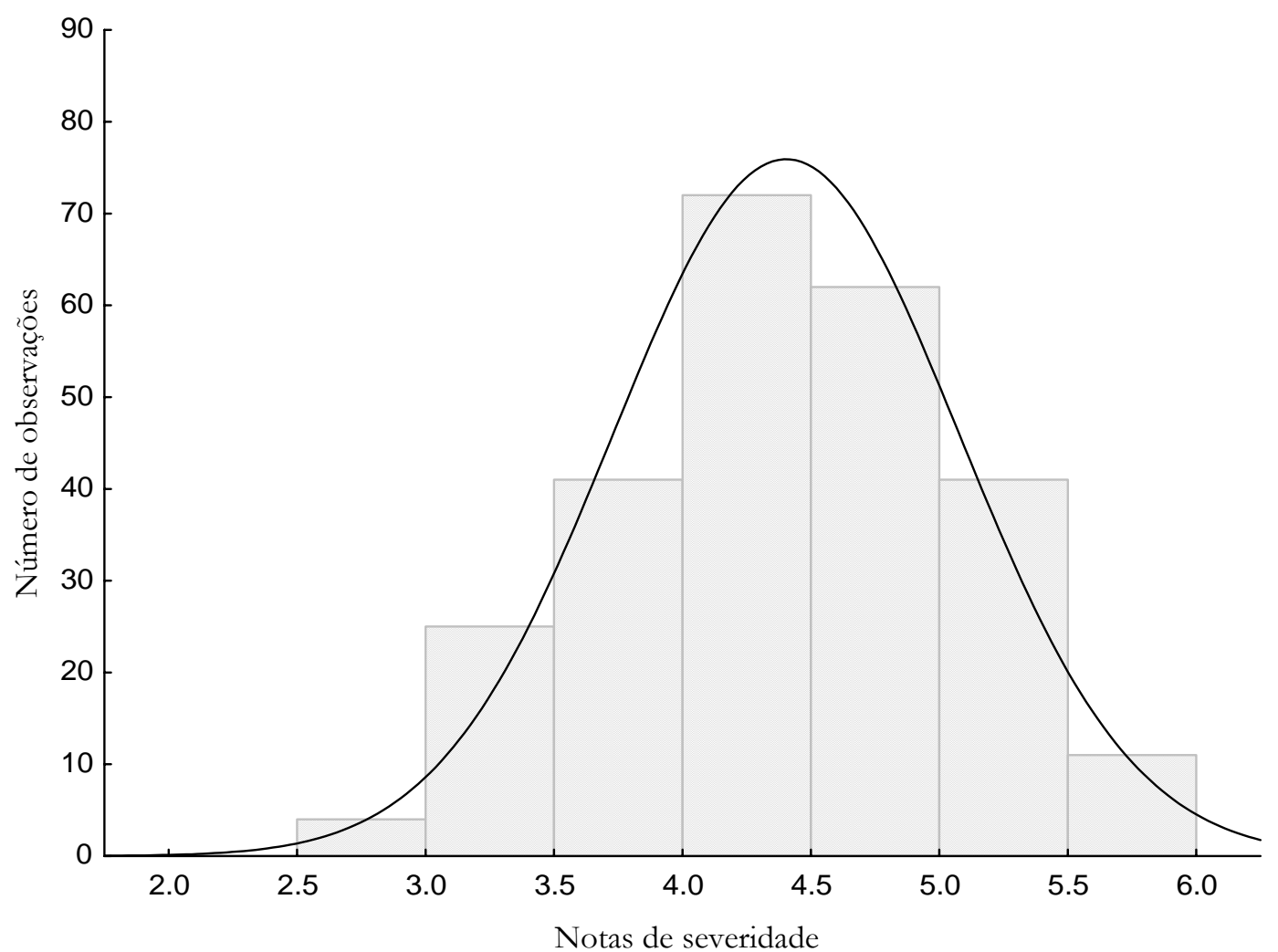

Figura 1 - Histograma e distribuição das médias ajustadas do caráter severidade da Phaeosphaeria maydis 


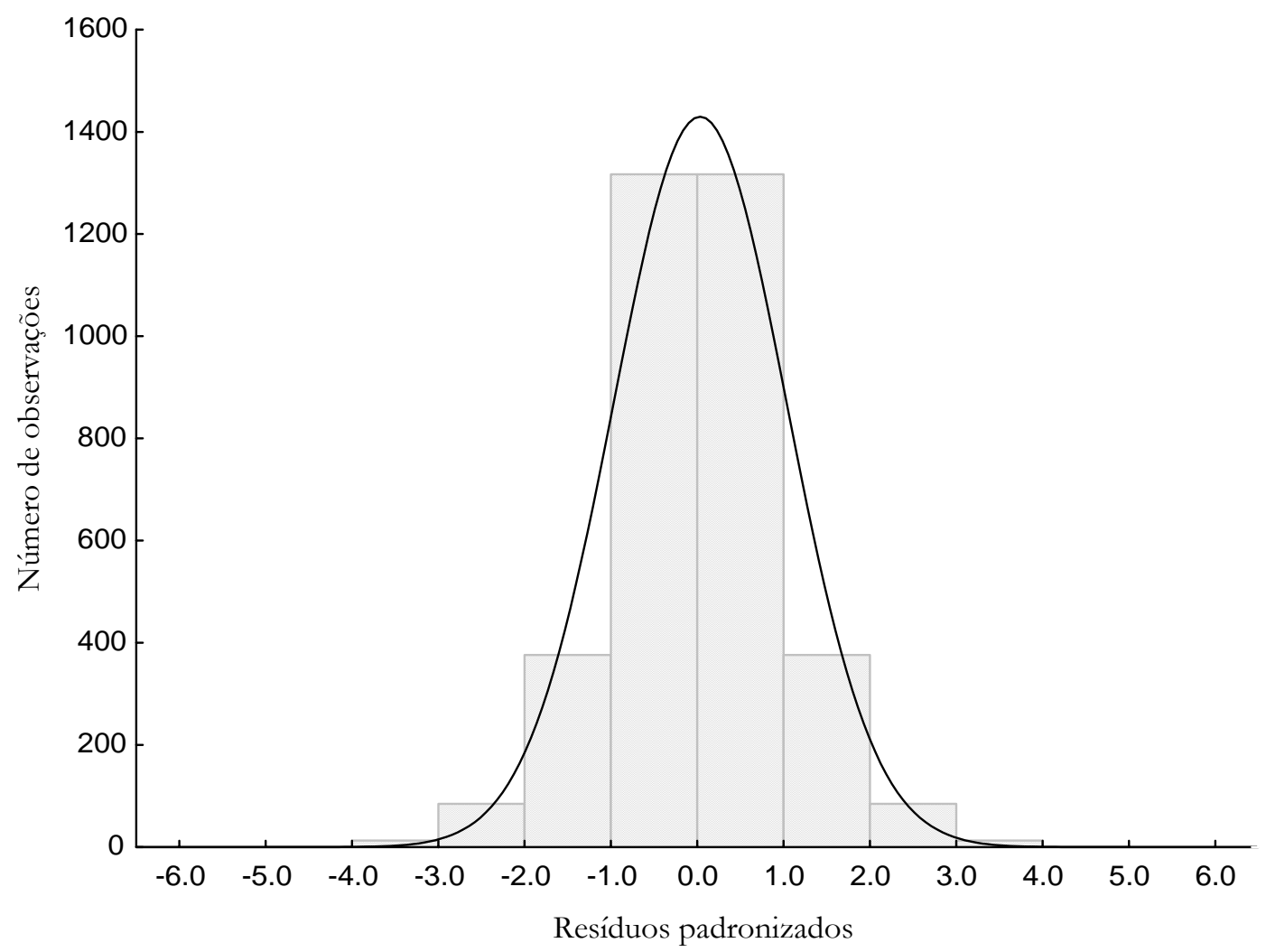

Figura 2 - Histograma e distribuição dos resíduos padronizados do caráter severidade da Phaeosphaeria maydis 
Cromossomo 1

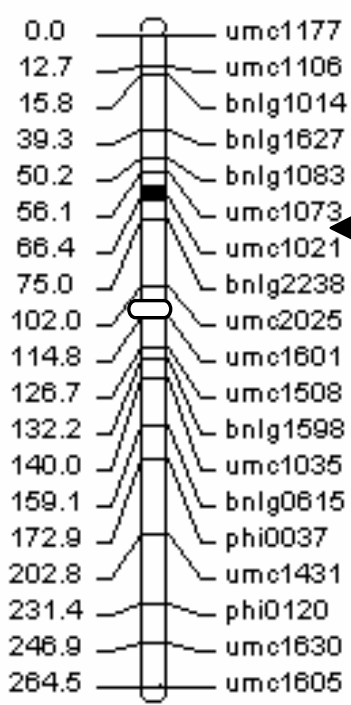

Cromossomo 3

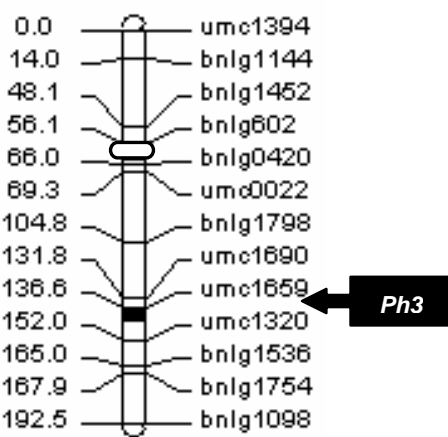

Cromossomo 2

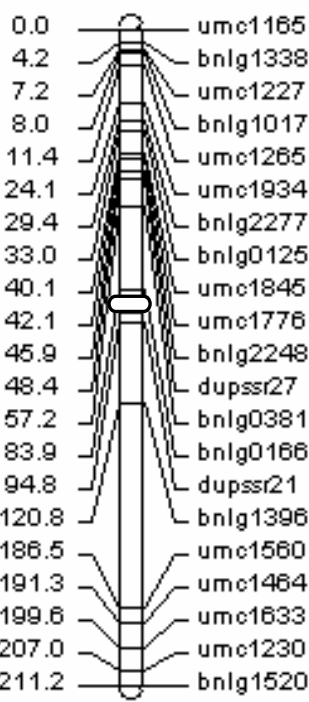

Cromossomo 4

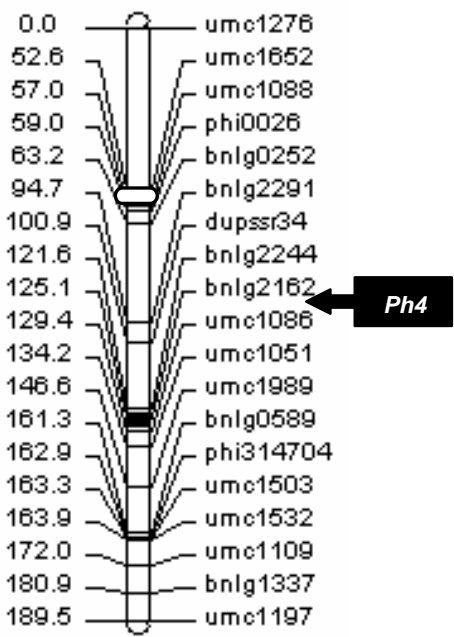

Figura 3 - Mapa genético dos cromossomos 1 a 4. Os números à esquerda dos cromossomos são as distâncias em $\mathrm{cM}$ a partir do primeiro marcador e à direita estão os nomes dos marcadores microssatélites. As marcas elípticas brancas referem-se aos centrômeros, as marcas escuras e as setas à direita referem-se às posições dos QTLs de resistência/susceptibilidade à Phaeosphaeria maydis 
Cromossomo 5

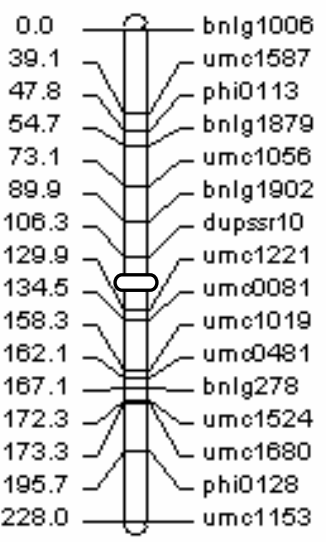

Cromossomo 7

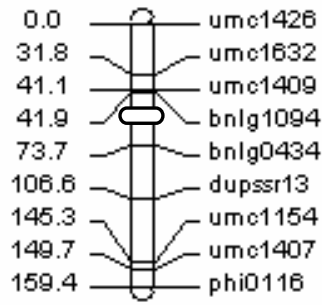

Cromossomog

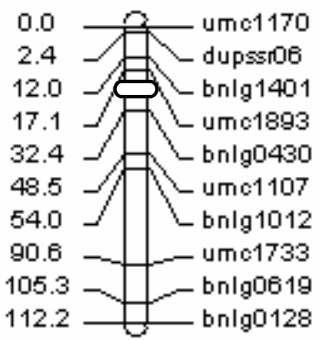

\section{Cromossomo 6}

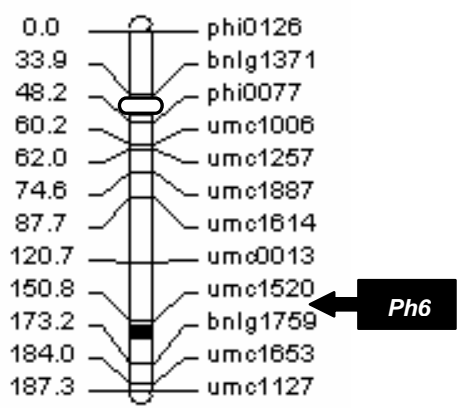

Cromossomo 8

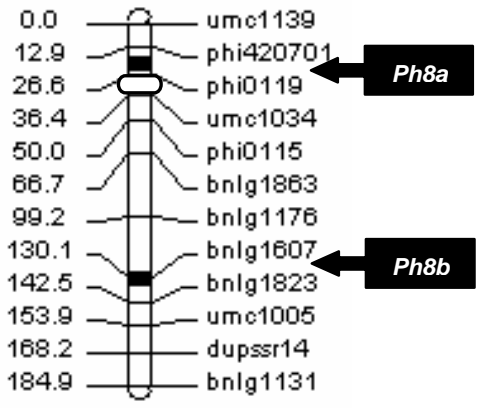

Cromossomo 10

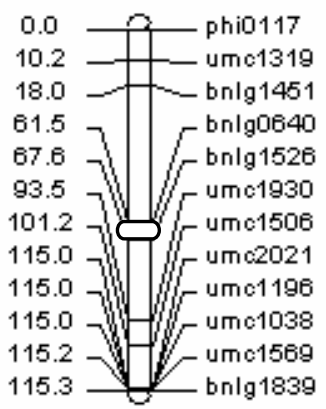

Figura 4 - Mapa genético dos cromossomos 5 a 10. Os números à esquerda dos cromossomos são as distâncias em cM a partir do primeiro marcador e à direita estão os nomes dos marcadores microssatélites. As marcas elípticas brancas referem-se aos centrômeros, as marcas escuras e as setas à direita referem-se às posições dos QTLs de resistência/susceptibilidade à Phaeosphaeria maydis 


\section{Cromossomo 1}

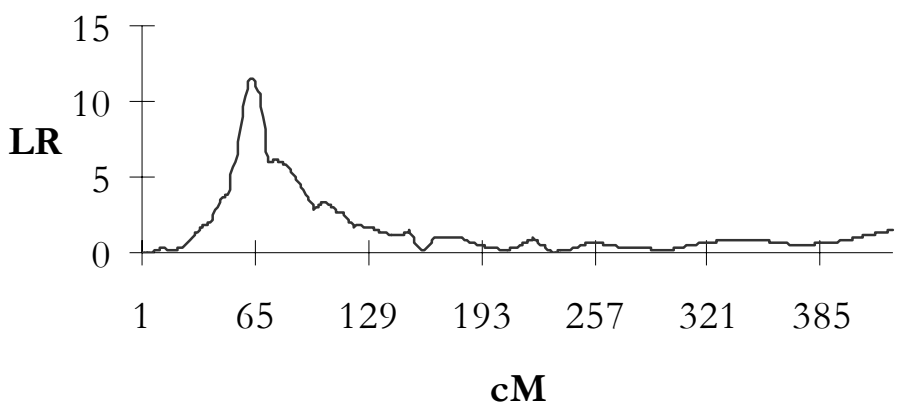

Cromossomo 3

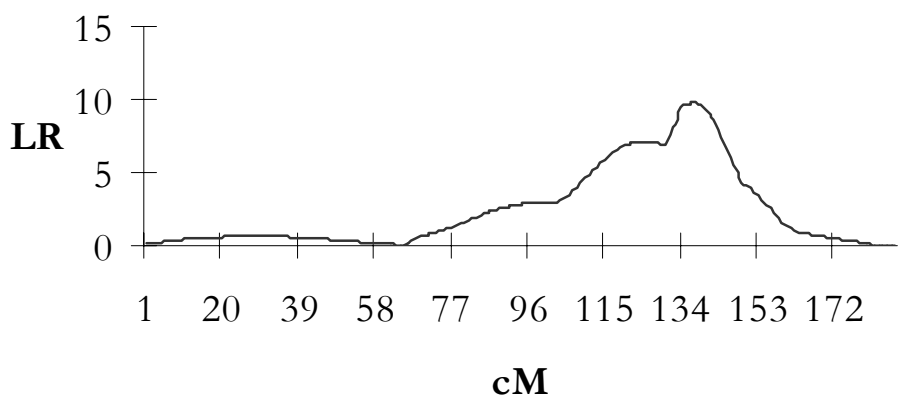

Figura 5 - Mapeamento de QTLs de resistência/susceptibilidade à doença causada por Phaeosphaeria maydis nos cromossomos 1 e 3 (Ph1 e Ph3). Cada pico representa um QTL, determinado pelo critério de informação Bayesiano 


\section{Cromossomo 4}

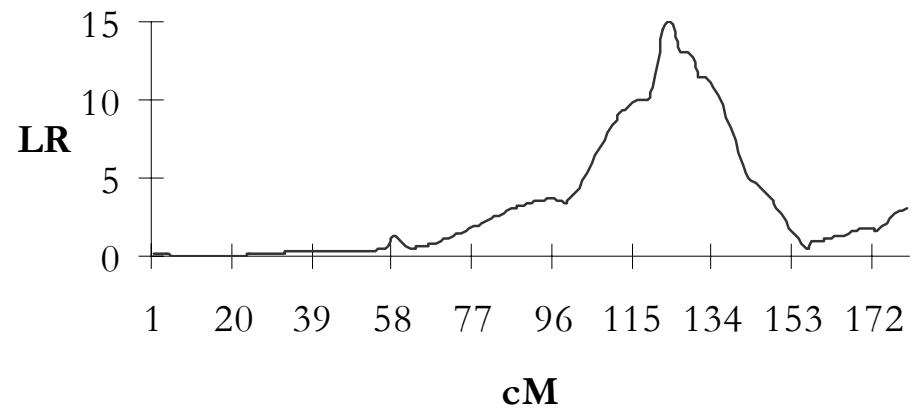

Cromossomo 6

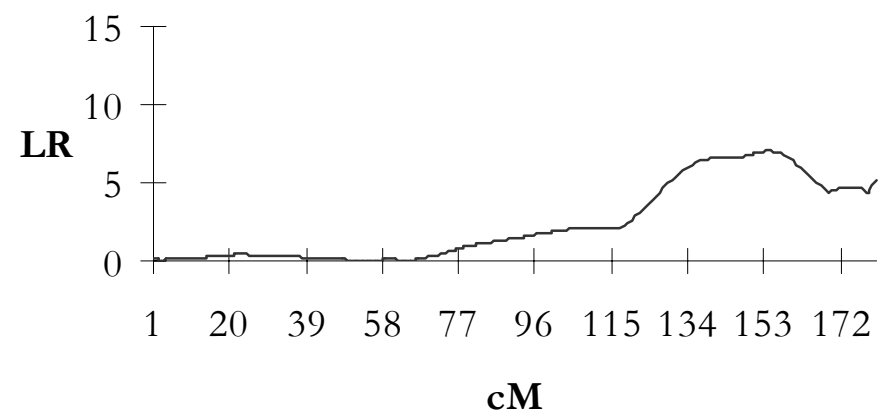

Figura 6 - Mapeamento de QTLs de resistência/susceptibilidade à doença causada por Phaeosphaeria maydis no cromossomo 4 e 6 (Ph4 e Ph6). Cada pico representa um QTL, determinado pelo critério de informação Bayesiano 


\section{Cromossomo 8}

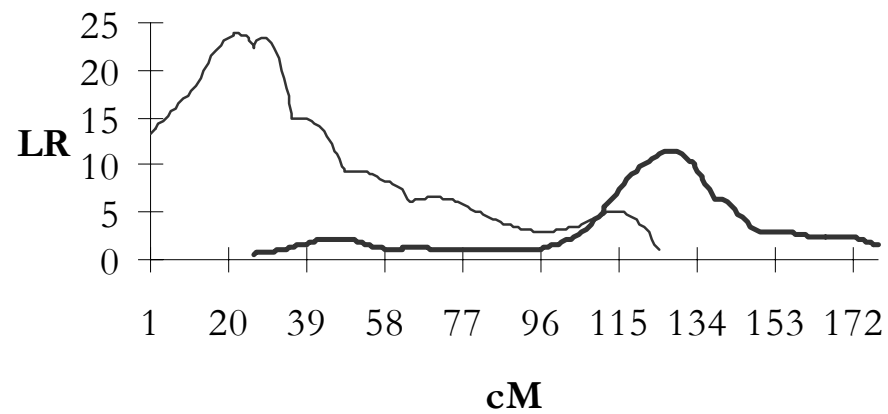

Figura 7 - Mapeamento de QTLs de resistência/susceptibilidade à doença causada por Phaeosphaeria maydis no cromossomo 8 (Ph8a e Ph8b). Cada pico representa um QTL, determinado pelo critério de informação Bayesiano

Tabela 4. Valores e significâncias dos quadrados médios $(\mathrm{QM})$ da análise conjunta de variância, coeficiente de variação experimental $(\mathrm{CV})$, média geral das progênies e seu intervalo de variação, e médias das linhagens parentais, para o caráter doença causada pela Phaeosphaeria maydis

\begin{tabular}{|c|c|c|c|}
\hline Fontes de variação & & GL & QM \\
\hline Ambientes (A) & & 6 & $407,35^{* *}$ \\
\hline Repetições (R) / A & & 7 & $65,74 * *$ \\
\hline Blocos / R / A & & 210 & $0,86^{* *}$ \\
\hline Progênies (P) & & 255 & $5,73^{* *}$ \\
\hline Progênies x Ambientes & & 1530 & $0,49 * *$ \\
\hline Resíduo & & 1575 & 0,26 \\
\hline $\mathrm{CV} \%$ & & 11,59 & \\
\hline Médias gerais & & Intervalos de confiança & Intervalo de variação \\
\hline Progênies & 4,40 & {$[4,06 ; 4,74]$} & 2,54 a 5,99 \\
\hline Genitor L 14-04B & 5,28 & {$[4,69 ; 5,88]$} & \\
\hline Genitor L 08-05F & 2,00 & {$[1,66 ; 2,34]$} & \\
\hline
\end{tabular}

** Significativo a $1 \%$ de probabilidade pelo teste $F$ 
Tabela 5. Valores e significâncias dos quadrados médios $(\mathrm{QM})$ das análises individuais de variância, coeficiente de variação experimental (CV), médias gerais das progênies e seus respectivos intervalos de variação, dos sete ambientes para o caráter doença causada pela Phaeosphaeria maydis

\begin{tabular}{|c|c|c|c|c|c|c|c|c|}
\hline \multirow[b]{2}{*}{ Fonte de variação } & \multirow[b]{2}{*}{ GL } & \multicolumn{7}{|c|}{ QM } \\
\hline & & $\begin{array}{c}\text { Genética } \\
02 / 03\end{array}$ & $\begin{array}{c}\text { Caterpillar } \\
02 / 03\end{array}$ & $\begin{array}{l}\text { Areão } \\
02 / 03\end{array}$ & $\begin{array}{c}\text { Anhembi } \\
02 / 03\end{array}$ & $\begin{array}{c}\text { Genética } \\
03 / 04\end{array}$ & $\begin{array}{c}\text { Caterpillar } \\
03 / 04\end{array}$ & $\begin{array}{c}\text { Anhembi } \\
03 / 04\end{array}$ \\
\hline Repetições (R) & 1 & $54,27 * *$ & $34,00 * *$ & $122,90 * *$ & $9,32 * *$ & $161,12^{* *}$ & $74,86^{* *}$ & $3,69 * *$ \\
\hline Blocos / R & 30 & $0,75^{* *}$ & $0,54 * *$ & $1,22^{* *}$ & $0,35^{* *}$ & $0,92^{* *}$ & $0,85^{* *}$ & $1,37 * *$ \\
\hline Progênies & 255 & $0,50 * *$ & $0,61 * *$ & $0,68^{* *}$ & $0,44^{* *}$ & $2,95^{* *}$ & $1,87^{* *}$ & $1,65^{* *}$ \\
\hline Resíduo & 225 & 0,11 & 0,15 & 0,32 & 0,09 & 0,47 & 0,35 & 0,36 \\
\hline CV $(\%)$ & & 12,54 & 9,55 & 12,29 & 5,44 & 14,22 & 12,12 & 13,04 \\
\hline Médias & & 2,60 & 4,02 & 4,58 & 5,39 & 4,81 & 4,85 & 4,57 \\
\hline Intervalos de Confiança & & {$[2,50 ; 2,70]$} & {$[3,91 ; 4,13]$} & {$[4,46 ; 4,69]$} & {$[5,29 ; 5,47]$} & {$[4,56 ; 5,04]$} & {$[4,65 ; 5,04]$} & {$[4,38 ; 4,75]$} \\
\hline Intervalos de Variação & & 1,47 a 4,21 & 2,56 a 5,43 & 2,82 a 6,60 & 3,80 a 6,73 & 1,60 a 7,57 & 2,02 a 6,97 & 1,88 a 6,86 \\
\hline
\end{tabular}

** Significativo a $1 \%$ de probabilidade pelo teste $F$ 
Tabela 6. Estimativas das variâncias fenotípicas, de progênies, interação progênies $\mathrm{x}$ ambientes e do coeficiente de herdabilidade para o caráter doença causada pela Phaeosphaeria maydis

\begin{tabular}{ccc}
\hline \multicolumn{2}{c}{ Parâmetros genéticos } & Intervalo de Confiança ${ }^{\mathbf{a}}$ \\
\hline$\hat{\sigma}_{\bar{F}}^{2}$ & 0,41 & {$[0,36 ; 0,48]$} \\
$\hat{\sigma}_{p}^{2}$ & 0,37 & {$[0,32 ; 0,44]$} \\
$\hat{\sigma}_{p a}^{2}$ & 0,12 & {$[0,10 ; 0,14]$} \\
$\hat{\sigma}^{2}$ & 0,26 & {$[0,24 ; 0,27]$} \\
$\hat{h}_{\bar{p}}^{2}(\%)$ & 91,37 & {$[89,9 ; 92,6]$} \\
\hline
\end{tabular}

${ }^{a}$ Intervalo de confiança $95 \%$ de probabilidade

Tabela 7. Correlações fenotípicas entre os setes ambientes para incidência da doença causada por Phaeosphaeria maydis

\begin{tabular}{|c|c|c|c|c|c|c|}
\hline AMBIENTES & $\begin{array}{c}\text { Caterpillar } \\
02 / 03\end{array}$ & $\begin{array}{l}\text { Areão } \\
02 / 03\end{array}$ & $\begin{array}{c}\text { Anhembi } \\
02 / 03\end{array}$ & $\begin{array}{c}\text { Genética } \\
03 / 04\end{array}$ & $\begin{array}{c}\text { Caterpillar } \\
03 / 04\end{array}$ & $\begin{array}{c}\text { Anhembi } \\
03 / 04\end{array}$ \\
\hline $\begin{array}{c}\text { Genética } \\
02 / 03\end{array}$ & $0,74 * *$ & $0,60 * *$ & $0,55^{* *}$ & $0,75^{* *}$ & $0,69 * *$ & $0,65^{* *}$ \\
\hline $\begin{array}{c}\text { Caterpillar } \\
02 / 03\end{array}$ & & $0,66^{* *}$ & $0,63^{* *}$ & $0,77^{* *}$ & $0,75^{* *}$ & $0,68^{* *}$ \\
\hline $\begin{array}{l}\text { Areão } \\
02 / 03\end{array}$ & & & $0,54 * *$ & $0,74 * *$ & $0,63 * *$ & $0,61^{* *}$ \\
\hline $\begin{array}{c}\text { Anhembi } \\
02 / 03\end{array}$ & & & & $0,65^{* *}$ & $0,67 * *$ & $0,66^{* *}$ \\
\hline $\begin{array}{c}\text { Genética } \\
03 / 04\end{array}$ & & & & & $0,77^{* *}$ & $0,73^{* *}$ \\
\hline $\begin{array}{c}\text { Caterpillar } \\
03 / 04\end{array}$ & & & & & & $0,72^{* *}$ \\
\hline
\end{tabular}

**Significativo a $1 \%$ de probabilidade pelo teste $t$ 
Tabela 8. Correlações genéticas entre os setes ambientes para incidência da doença causada por Phaeosphaeria maydis

\begin{tabular}{|c|c|c|c|c|c|c|}
\hline AMBIENTES & $\begin{array}{c}\text { Caterpillar } \\
02 / 03\end{array}$ & $\begin{array}{l}\text { Areão } \\
02 / 03\end{array}$ & $\begin{array}{c}\text { Anhembi } \\
02 / 03\end{array}$ & $\begin{array}{c}\text { Genética } \\
03 / 04\end{array}$ & $\begin{array}{c}\text { Caterpillar } \\
03 / 04\end{array}$ & $\begin{array}{c}\text { Anhembi } \\
03 / 04\end{array}$ \\
\hline $\begin{array}{l}\text { Genética } \\
02 / 03\end{array}$ & $0,96 * *$ & $0,93 * *$ & $0,67 * *$ & $0,95^{* *}$ & $0,87 * *$ & $0,81 * *$ \\
\hline $\begin{array}{c}\text { Caterpillar } \\
02 / 03\end{array}$ & & $1,03^{* *}$ & $0,79 * *$ & $0,98^{* *}$ & $0,95^{* *}$ & $0,90 * *$ \\
\hline $\begin{array}{l}\text { Areão } \\
02 / 03\end{array}$ & & & $0,86 * *$ & $1,04 * *$ & $0,91 * *$ & $0,88^{* *}$ \\
\hline $\begin{array}{c}\text { Anhembi } \\
02 / 03\end{array}$ & & & & $0,81 * *$ & $0,85^{* *}$ & $0,79 * *$ \\
\hline $\begin{array}{c}\text { Genética } \\
03 / 04\end{array}$ & & & & & $0,90 * *$ & $0,89 * *$ \\
\hline $\begin{array}{c}\text { Caterpillar } \\
03 / 04\end{array}$ & & & & & & $0,90 * *$ \\
\hline
\end{tabular}

Tabela 9. Correlações residuais entre os setes ambientes para incidência da doença causada por Phaeosphaeria maydis

\begin{tabular}{|c|c|c|c|c|c|c|}
\hline AMBIENTES & $\begin{array}{c}\text { Caterpillar } \\
02 / 03\end{array}$ & $\begin{array}{l}\text { Areão } \\
02 / 03\end{array}$ & $\begin{array}{c}\text { Anhembi } \\
02 / 03\end{array}$ & $\begin{array}{c}\text { Genética } \\
03 / 04\end{array}$ & $\begin{array}{c}\text { Caterpillar } \\
03 / 04\end{array}$ & $\begin{array}{c}\text { Anhembi } \\
03 / 04\end{array}$ \\
\hline $\begin{array}{l}\text { Genética } \\
02 / 03\end{array}$ & $-0,02$ ns & 0,00 ns & $0,08 \mathrm{~ns}$ & $-0,11$ ns & $-0,03$ ns & $0,08^{\mathrm{ns}}$ \\
\hline $\begin{array}{c}\text { Caterpillar } \\
02 / 03\end{array}$ & & $0,01 \mathrm{~ns}$ & $0,06^{\mathrm{ns}}$ & $-0,09$ ns & $0,02 \mathrm{~ns}$ & $-0,06^{\mathrm{ns}}$ \\
\hline $\begin{array}{l}\text { Areão } \\
02 / 03\end{array}$ & & & $-0,07$ ns & $0,16^{\mathrm{ns}}$ & $0,10^{\mathrm{ns}}$ & $0,12^{\mathrm{ns}}$ \\
\hline $\begin{array}{c}\text { Anhembi } \\
02 / 03\end{array}$ & & & & $-0,08^{\mathrm{ns}}$ & $-0,08^{\mathrm{ns}}$ & $0,14^{\mathrm{ns}}$ \\
\hline $\begin{array}{c}\text { Genética } \\
03 / 04\end{array}$ & & & & & $0,12^{\mathrm{ns}}$ & $0,02^{\mathrm{ns}}$ \\
\hline $\begin{array}{c}\text { Caterpillar } \\
03 / 04\end{array}$ & & & & & & $0,00^{\mathrm{ns}}$ \\
\hline
\end{tabular}

nsNão significativo 
Tabela 10. Localização, estimativas dos efeitos genéticos, epistáticos e ação gênica dos QTLs de reacão à Phaeosphaeria mavdis

\begin{tabular}{|c|c|c|c|c|c|c|c|c|c|c|c|}
\hline \multirow[b]{2}{*}{ QTLs } & \multicolumn{5}{|c|}{ Posição do QTL } & \multicolumn{3}{|c|}{ Efeito genético $^{b}$} & \multicolumn{3}{|c|}{ Ação gênica ${ }^{\mathrm{d}}$} \\
\hline & Cromossomo & Intervalo entre marcas & Bin $^{a}$ & $\begin{array}{c}(\mathrm{cM}) \\
\text { Marca à } \\
\text { esquerda }\end{array}$ & $\begin{array}{l}\text { (cM) } \\
\text { Posição a partir } \\
\text { do início }\end{array}$ & Aditivo & Dominante & $\mathbf{R}^{2}(\%)^{\mathrm{c}}$ & IdI/IaI & Tipo & Direção \\
\hline$P h 1$ & 1 & umc1073 - umc1021 & $1.03-1.03$ & 9,00 & 65,11 & $-0,25$ & 0,17 & 5,77 & 0,70 & DP & L $08-05 F$ \\
\hline $\mathrm{Ph} 3$ & 3 & umc1659 - umc1320 & $3.07-3.08$ & 3,00 & 139,60 & $-0,25$ & 0 & 5,77 & 0 & A & L 08-05F \\
\hline Ph4 & 4 & bnlg2162 - umc1086 & $4.08-4.08$ & 1,00 & 126,07 & $-0,30$ & 0,09 & 6,49 & 0,31 & DP & L 08-05F \\
\hline Ph6 & 6 & umc1520 - bnlg1759 & $6.06-6.07$ & 7,00 & 157,80 & $-0,20$ & $-0,04$ & 5,40 & 0,18 & A & L 08-05F \\
\hline $\mathrm{Ph} 8 \mathrm{a}$ & 8 & phi420701 - phi0119 & $8.00-8.02$ & 9,00 & 21,87 & $-0,31$ & $-0,09$ & 11,86 & 0,29 & DP & L 08-05F \\
\hline Ph8b & 8 & bnlg1607 - bnlg1823 & $8.06-8.07$ & 1,00 & 131,14 & $-0,18$ & $-0,11$ & 2,91 & 0,62 & DP & L 08-05F \\
\hline Ph8a X Pb8b & 8 & 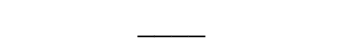 & 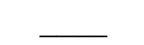 & 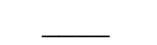 & 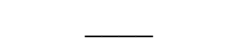 & - & 0,56 & 3,41 & & $\mathrm{D} \times \mathrm{D}$ & L 08-05F \\
\hline & & & & & & & Total: & 41,62 & $0,32^{\mathrm{e}}$ & DP & \\
\hline
\end{tabular}

${ }^{a}$ Localização do bin designado pela codificação X.Y, onde X refere-se ao grupo de ligação e Y é a localização do bin dentro do grupo de ligação

bAditivo: Efeito de substituição dos alelos da L 08-05F pelos alelos da L 14-04B. Valor negativo indica efeito no sentido de diminuição do valor do caráter pela L 08-05F, aumentando a resistência à doença. Dominância: Efeito dos alelos da L 08-05F sobre os alelos da L 14-04B. Valor positivo indica que o heterozigoto possui em média valor fenotípico superior à média dos dois homozigotos. Valor negativo indica que o heterozigoto possui em média valor fenotípico inferior à média dos dois homozigotos

cPorcentagem da variação fenotípica explicada pelo QTL

dAção gênica determinada pelo grau de dominância $(G D=|d| /|a|)$ para cada QTL

egrau médio de dominância (GMD) obtido pela média ponderada pelo $\mathrm{R}^{2}$,Tipos: Aditiva $(\mathrm{A})=0$ a 0,2 ; Dominância Parcial $(\mathrm{DP})=0,21$ a 0,$80 ;$ Dominância completa $(\mathrm{D})=0,81$ a 1,2; e Sobredominância (SD) $>1,2$ (Stuber et al., 1987) 
Tabela 11. Progênies selecionadas com seus respectivos valores fenotípicos médios e valores genotípicos preditos, médias das progênies selecionadas e respectivos diferenciais de seleção

\begin{tabular}{|c|c|c|c|c|c|c|c|c|}
\hline \multirow{2}{*}{$\begin{array}{c}\text { Classificação } \\
\text { das } \\
\text { progênies } \\
\text { selecionadas }\end{array}$} & \multicolumn{4}{|c|}{ Seleção com médias } & \multicolumn{4}{|c|}{ Seleção com valores genotípicos } \\
\hline & $\begin{array}{l}\text { Número } \\
\text { da } \\
\text { progênie }\end{array}$ & $\begin{array}{l}\text { Notas } \\
\text { médias } \\
(\mathbf{M})\end{array}$ & $\begin{array}{l}\text { Valor } \\
\text { genotípico } \\
\text { predito } \\
\text { (P) }\end{array}$ & $\begin{array}{c}\text { Desvios } \\
\text { (M-P) }\end{array}$ & $\begin{array}{l}\text { Número } \\
\text { da } \\
\text { progênie }\end{array}$ & $\begin{array}{l}\text { Valor } \\
\text { genotípico } \\
\text { predito } \\
\text { (P) }\end{array}$ & $\begin{array}{l}\text { Notas } \\
\text { médias } \\
\text { (M) }\end{array}$ & $\begin{array}{c}\text { Desvios } \\
\text { (P-M) }\end{array}$ \\
\hline $1^{\circ}$ & 118 & 2,54 & 3,42 & $-0,88$ & 98 & 3,37 & 3,38 & $-0,01$ \\
\hline $2^{\circ}$ & 40 & 2,71 & 3,82 & $-1,11$ & 57 & 3,37 & 3,34 & 0,04 \\
\hline $3^{\circ}$ & 121 & 2,92 & 3,53 & $-0,61$ & 118 & 3,42 & 2,54 & 0,88 \\
\hline $4^{\circ}$ & 12 & 2,98 & 3,92 & $-0,94$ & 132 & 3,42 & 3,41 & 0,01 \\
\hline $5^{\circ}$ & 15 & 3,05 & 3,64 & $-0,59$ & 121 & 3,53 & 2,92 & 0,61 \\
\hline $6^{\circ}$ & 119 & 3,09 & 4,14 & $-1,05$ & 114 & 3,55 & 3,27 & 0,28 \\
\hline $7^{\circ}$ & 173 & 3,12 & 4,05 & $-0,93$ & 202 & 3,56 & 3,47 & 0,09 \\
\hline $8^{\circ}$ & 128 & 3,12 & 3,73 & $-0,61$ & 93 & 3,56 & 4,66 & $-1,09$ \\
\hline $9^{\circ}$ & 70 & 3,18 & 3,91 & $-0,73$ & 15 & 3,64 & 3,05 & 0,59 \\
\hline $10^{\circ}$ & 36 & 3,20 & 3,79 & $-0,59$ & 251 & 3,66 & 3,28 & 0,37 \\
\hline $11^{\circ}$ & 127 & 3,27 & 4,13 & $-0,86$ & 217 & 3,69 & 3,37 & 0,32 \\
\hline $12^{\circ}$ & 114 & 3,27 & 3,55 & $-0,28$ & 66 & 3,70 & 3,55 & 0,14 \\
\hline $13^{\circ}$ & 251 & 3,28 & 3,66 & $-0,37$ & 128 & 3,73 & 3,12 & 0,61 \\
\hline $14^{\circ}$ & 59 & 3,30 & 4,07 & $-0,77$ & 151 & 3,75 & 3,61 & 0,14 \\
\hline $15^{\circ}$ & 23 & 3,34 & 4,37 & $-1,03$ & 233 & 3,78 & 3,68 & 0,10 \\
\hline $16^{\circ}$ & 57 & 3,34 & 3,37 & $-0,04$ & 243 & 3,78 & 3,78 & 0,00 \\
\hline $17^{\circ}$ & 217 & 3,37 & 3,69 & $-0,32$ & 126 & 3,78 & 3,84 & $-0,06$ \\
\hline $18^{\circ}$ & 98 & 3,38 & 3,37 & 0,01 & 36 & 3,79 & 3,20 & 0,59 \\
\hline $19^{\circ}$ & 206 & 3,38 & 3,85 & $-0,46$ & 64 & 3,79 & 4,29 & $-0,50$ \\
\hline $20^{\circ}$ & 16 & 3,38 & 4,57 & $-1,19$ & 84 & 3,81 & 3,60 & 0,21 \\
\hline $21^{\circ}$ & 171 & 3,39 & 4,11 & $-0,72$ & 167 & 3,81 & 4,36 & $-0,55$ \\
\hline $22^{\circ}$ & 132 & 3,41 & 3,42 & $-0,01$ & 40 & 3,82 & 2,71 & 1,11 \\
\hline $23^{\circ}$ & 150 & 3,41 & 4,02 & $-0,61$ & 214 & 3,83 & 4,74 & $-0,91$ \\
\hline $24^{\circ}$ & 37 & 3,42 & 4,01 & $-0,59$ & 39 & 3,83 & 5,00 & $-1,17$ \\
\hline $25^{\circ}$ & 144 & 3,44 & 3,86 & $-0,42$ & 253 & 3,84 & 4,24 & $-0,40$ \\
\hline $26^{\circ}$ & 47 & 3,46 & 3,92 & $-0,46$ & 55 & 3,84 & 4,03 & $-0,19$ \\
\hline \multicolumn{2}{|c|}{ Média da seleção $5 \%$} & 3,06 & & & & 3,55 & & \\
\hline \multicolumn{2}{|c|}{ Média da seleção $10 \%$} & 3,22 & & & & 3,68 & & \\
\hline \multicolumn{2}{|l|}{ Média geral } & 4,40 & & & & 4,40 & & \\
\hline \multicolumn{2}{|c|}{ Diferencial seleção 5\% (ds) } & $-1,35$ & & & & $-0,85$ & & \\
\hline \multicolumn{2}{|c|}{ Diferencial seleção $10 \%$ (ds) } & $-1,18$ & & & & $-0,73$ & & \\
\hline
\end{tabular}




\section{REFERÊNCIAS BIBLIOGRÁFICAS}

AGROCERES. Guia Agroceres de sanidade. São Paulo: Sementes Agroceres, 1996. $72 \mathrm{p}$.

AMORIM, L. Avaliação de doenças. In: BERGAMIN FILHO, A; KIMATI, H.; AMORIM, L. (Ed.). Manual de Fitopatologia. 3.ed. São Paulo: Agronômica Ceres, 1995a. v.1, p.647-671.

AMORIM, L. Colonização e reprodução. In: BERGAMIN FILHO, A; KIMATI, H.; AMORIM, L. (Ed.). Manual de Fitopatologia. 3.ed. São Paulo: Agronômica Ceres, 1995b. v.1, p.309-323.

BALMER, E., PEREIRA, O.A.P. Doenças do milho. In: Paterniani, E., Viégas, G.P. Melhoramento e produção de milho. 2.ed. Campinas: Fundação Cargill, 1987. v.2, p.595-634.

BARBIN, D. Componentes de variância: teoria e aplicações. 2.ed. Piracicaba: FEALQ, 1993. 120p.

BASTEN, C.J., WEIR, B.S.; ZENG, Z.-B. QTL Cartographer, Version 1.17. Department of Statistics, Noth Carolina State University, Raleigh, NC, 2003.

BEARZOTI, E. Mapeamento de QTL. In: PINHEIRO, J.B. Análise de QTL no melhoramento de plantas: segunda jornada em Genética e melhoramento de plantas. Goiânia: FUNAPE, 2000. p.63-209. 
BEDENDO, I.P. Manchas foliares. In: BERGAMIN FILHO, A; KIMATI, H.; AMORIM, L. (Ed.). Manual de Fitopatologia. 3.ed. São Paulo: Agronômica Ceres, 1995. v.1, p.848-858.

BENCHIMOL, L.L. Seleção assistida por marcadores moleculares microssátelites em programas de retrocruzamentos em milho (Zea mays L.). Campinas, 2002. 102p. Tese (Doutorado) - Universidade Estadual de Campinas.

BORECKI, I.B.; SUAREZ, B.K. Linkage and assiciation: basic concepts. In: RAO, D.C.; PROVINCE, M.A. (Eds.) Genetic dissection of complex traits. San Diego: Academic Press, 2001. 583p.

BORÉM, A. Melhoramento de plantas. 2.ed. Viçosa: UFV, 1998. 453p.

BOUCHEZ, A.; HOSPITAL, F.; CAUSSE, M.; GALlAis, A.; CHARCOSSET, A. Market-assisted introgression of favorable alleles at quantitative trait loci between maize elite lines. Genetics, v.162, p.1945-1959, 2002.

BRASIL, E.M.; CARVALHO, Y. Comportamento de híbridos de milho em relação a Phaeosphaeria maydis em diferentes épocas de plantio. Pesquisa Agropecuaria Brasileira, Brasília, v.33, n.12, p.1977-1981, 1998.

CAMARGO, L.E.A. Análise genética da resistência e da patogenicidade. In: BERGAMIN FILHO, A; KIMATI, H.; AMORIM, L. (Ed.). Manual de Fitopatologia. 3.ed. São Paulo: Agronômica Ceres, 1995. v.1, p.470-491.

CARSON, M.L. Inheritance of resistence to Phaeosphaeria leaf spot of maize. Plant Disease, v.85, n.7, p.798-800, 2001.

CAMPBELL, C.L.; MADDEN, L.V. Introduction to plant disease epidemiology. New York: John Wiley \& Sons, 1990. 532p. 
CARSON, M.L.; STUBER, C.W.; SENIOR, M.L. Identification of quantitative trait loci (QTLs) for resistance to two foliar diseases in a mapping population of recombinant inbred (RI) lines of maize. Phytopathology, v.86, p.S59, 1996. /Abstracts/

CARSON, M.L; STUBER, C.W.; SENIOR, M.L. Quantitative trait loci conditioning resistence to Phaeosphaeria leaf spot of maize caused by Phaeosphaeria maydis. Plant Disease, Aug. 2004. /No prelo/

CARSON, M.L. Vulnerability of U. S. maize germ plasm to Phaeosphaeria leaf spot. Plant Disease, v.83, n.5, p.462-464, 1999.

CARTER, T.C.; FALCONER, D.S. Stocks for detecting linkage in the mouse and theory of their design. Journal of Genetics, v.50, p.307-323, 1951.

CASELA, C.R.; FERREIRA, A.S.; FERNANDES, F.T; PINTO, N.F.J.A. Comunicado técnico 48. Brasília: Embrapa/CNPMS, 2002, 5p.

CHESTER, K.S. Plant disease losses: their appraisal and interpretation. Plant Disease Reporter, v.193, p.191-362, 1950. Supplement.

CHURCHILL, G.A.; DOERGE, R.W. Empirical threshold values for quantitative trait mapping. Genetics, v.138, p.963-971, 1994.

COCHRAN, W.G.; COX, G.M. Experimental design. 2.ed. New York: John Wiley e Sons, 1966. 611p.

COCKERHAM, C.C. An extension of the concept of partitioning hereditary variance for analysis of covariance among relatives when epistasis is present. Genetics, v.39, p.859882, 1954. 
CONTE, R. Estrutura genética de populações de Euterpe edulis MART. Submetidas à ação antrópica utilizando marcadores alozímicos e microssátelites. Piracicaba, 2004. 124p. Tese (Doutorado) - Escola Superior de Agricultura “Luiz de Queiroz”, Universidade de São Paulo.

DAS, S.N.; CHATTOPADHYAY, S.B. Studies on diseases of maize I: Foliar diseases. Indian Journal of Mycology Research, v.22, n.1, p.9-20, 1984.

DAS, S.N.; PRODHAN, H.S.; KAISER, S.A, K.M. Further studies on the inheritance of resistence to Phaeosphaeria leaf spot of maize. Indian Journal of Mycology Research, v.27, n.2, p.127-130, 1989a.

DAS, S.N., SINHAMAHAPATRA, S.P.; BASAK, S.L. Inheritance of resistence to Phaeosphaeria leaf spot of maize. Annual of Agricultural Research, v.10, n.2, p.182184, 1989b.

DOERGE, R.W.; CHURCHILL. G.A. Permutation tests for multiple loci affecting a quantitative character. Genetics, v.142, p.285-294, 1996.

DON, R.H.; COX, P.T.; WAINWRIGHT, B.J.; BAKER, K; MATTICK, J.S. Touchdown PCR to circumvent spurious priming during gene amplification. Nucleic Acid Reseach, v.19, p.4008, 1991.

DUDLEY, J. W. Molecular markers in plant improvement: manipulation of genes affeting quantitative traits. Crop Sciences, v.33, p.660-668, 1993.

DUDIENAS, C.; DIARTE, A.P.; PATERNIANI, M.E.A.; CASTRO, J.L.; GOZI, C.; VASCONCELOS, J.A.M.; GELLER, C.; PAVÃO, L.A. Severidade da mancha de Phaeosphaeria em cultivares de milho safrinha. Summa Phytopathologica, v.24, n.1, p.78, 1998. /Resumo/ 
EDWARDS, M.D.; STUBER, C.W.; WENDEL, J.F. Molecular-marker-facilitated investigations of quantitative-trait loci in maize. I. Numbers, genomic distribution and types of gene action. Genetics, v.116, p.113-125, 1987.

EMPRESA BRASILEIRA DE PESQUISA AGROPECUÁRIA. Recomendações técnicas para a cultura do milho. Brasília: Embrapa, 1993. 204p.

FALCONER, D.S.; MACKAY, T.F.C. Introduction to Quantitative Genetics. 4.ed. London: Longman Scientific e Technical, 1996. 464p.

FANTIN, G.M. Mancha de Phaeosphaeria, doença do milho que vem aumentando sua importância. Biológico, v.56, n.1, p.39, 1994.

FELSENSTEIN, J. A mathematically tractable family of genetic mapping functions with differents amount of interference. Genetics, v.91, p. 769-775, 1979.

FERNANDES, F.T.; OLIVEIRA, E. Principais doenças da cultura do milho. Sete Lagoas: EMBRAPA. 1997, p.12-21.

FERREIRA, M.E.; GATTAPAGLIA, D. Introdução ao uso de marcadores moleculares em análise genética. 3.ed., Brasília: EMBRAPA-CENARGEN, 1998. $220 \mathrm{p}$.

GARCIA, A.F. Mapeamento de QTLs para caracteres de importância agronômica em duas populações $F_{2}$ de milho tropical. Campinas, 2003. 110p. Dissertação (Mestrado) Universidade de Campinas.

GODOY, C.V.; AMORIM, L.; BERGAMIN FILHO, A. Efeito da mancha de Phaeosphaeria na eficiência fotossintética de plantas de milho. Fitopatologia Brasileira, v.23, 1998. Suplemento: 246. /Apresentado ao XXXI Congresso Brasileiro de Fitopatologia, Fortaleza, 1998 - Resumo/ 
GRIFFITHS, A.J.; MILLER, J.H.; SUZUKI, D.T.; LEWONTIN, R.C.; GELBART, W.M. An introduction to genetic analysis. New York: W. H. Freeman, 2000. p.1-103.

HALDANE, J.B.S. The recombination of linkage values and the calculation of distance between the loci of linkage factors. Journal of Genetics, v.8, p.299-309, 1919.

HENNINGS, P. Fungi S. paulenses II a cl. Puttemans collecti. Hedwigia, v.41, p.295-311, 1902.

HOISINGTON, D.; KHAIRALLAH, M.M.; GONZALES-DE-LÉON, D. Laboratory protocols. CIMMYT applied molecular genetics laboratory. 2.ed. México: CIMMYT, 1994. 180p.

JANSEN, R.C.; STAM, P. High resolution of quantitative traits into multiple loci via interval mapping. Genetics, v.136, p.1447-1455, 1994.

JIANG, C.; EDMEADES, G.O.; ARMSTEAD, I.; LAFITTE, H.R.; HAYWARD, M.D.; HOISINGTON, D. Genetic analysis of adaptation differences between highland and lowland tropical maize using molecular markers. Theoretical and Applied Genetics, v.99, p.1106-1119, 1999.

JIANG, C.; ZENG, Z. Multiple trait analysis of genetic mapping for quantitative trait loci. Genetics, v.140, p.1111-1127, 1995.

KAO, C. H.; ZENG, Z.-B.; TEASDALE, R. D. Multiple interval mapping for quantitative trait loci. Genetics, v.152, p.1203-1216, 1999.

KARLIN, S.; LIBERMAN, U. A natural class of multilocus recombination processes and related measure of crossover interference. Advances in Applied Probabily, v.11, p.479-501, 1979. 
KARLIN, S.; LIBERMAN, U. Classification and comparisons of multilocus recombination distribution. Proceedings of the National Academy of Science, v.75, p.6332-6336, 1978.

KARLIN, S. Theoretical aspects of genetics map functions in recombination processes. In: Chakravarti, A. (Ed.). Human population genetics: the Pittsburgh symposium. New York: Van Nostrand Reinhold, 1982. p.245-286.

KNAPP, S.J.; STROUP, W.W.; ROSS, W.M. Exact confidence intervals for heritability on a progeny mean basis. Crop Science, v.25, n.1, p.192-194, 1985.

KOSAMBI, D.D. The estimation of map distances from recombination values. Annual Eugenics, v.12, p.172-175, 1944.

LANDER, E.S.; BOTSTEIN, D. Mapping mendelian factors underlying quantitative traits using RFLP linkage maps. Genetics, v.121, p.185-199, 1989.

LANDER, E.S.; GREEN, P.; ABRAHAMSON, J.; BARLOW, A.; DALY, M.J.; LINCOLN, S.E.; NEWBURG, L. Mapmaker: an interactive computer package for constructing primary genetic linkage maps of experimental and natural populations. Genomics, v.1, p.174-181, 1987.

LEE, M. DNA markers and plant breeding programs. Advances in Agronomy, v.55, p.265-344, 1995.

LINCOLN, S.E.; DALY, M.J.; LANDER, E.S. Constructing genetic maps with Mapmaker Exp 3.0. 3.ed. Cambridge: Whitehead Institute for Biometrical Research, 1992. 230p.

LIU, B.H.; KNAPP, S.J. G. Mendel: a program for mendelian segregation and linkage analysis of individual or multiple progeny populations using log-likelihood ratios. Journal of Heredity, v.81, p.407, 1992. 
LIU, B.H. QTL mapping: future considerations. In: LIU, B.H. (Ed.). Statistic genomics. New York: CRC Press, 1998. 611p.

LOPES, M.T.G. Mapeamento de genes de resistência a mancha de Phaeosphaeria em milho. Piracicaba, 2003. 117p. Dissertação (Doutorado) - Escola Superior de Agricultura "Luiz de Queiroz", Universidade de São Paulo.

LUDWIG, W. Ubernumerische beziehungen der crossover-werte untereinander. Zeitschrift für Induktive Abstammungs - Und Vererbungslehre, v.67, p.58-95, 1934.

LYNCH, M.; WALSH, B. Genetics and analysis of quantitative traits. Sunderland: Sinauer Associates, 1998. 980p.

MACKAY, T.F.C. Quantitative trait in Drosophila. Nature Reviews Genetics, v.2, p.1120, 2001.

MANGOLIN, C.A.; de SOUZA JÚNIOR, C.L.; GARCIA, A.A.F.; GARCIA, A.F.; SIBOV, S.T.; de SOUZA, A.P. Mapping QTLs for kernel oil content in a tropical maize population. Euphytica, v.137, p.251-259, 2004.

MATHER, K.; JINKS, J.L. Introdução à genética biométrica. Trad. de J.F.M. Duarte, F.M. Sene, H.A. Rothschild et al. Ribeirão Preto: Sociedade Brasileira de Genética, 1984. 242p.

McMULLEN, M.D.; SIMCOX, K.D. Clustering of disease resistence loci in the maize genome. Newsletter, n.69, p.52-53, 1995a.

McMULLEN, M.D.; SIMCOX, K.D. Genomic organization of disease and insect resistence genes in maize. Molecular Plant-Microbe Interactions, v.8, p.811-815, 1995b.

MULLIS, K.; FALOONA, F. Specific synthesis of DNA in vitro via a polymerase catalysed chain reaction. Methods Enzymology, v.55, p.335-350, 1987. 
MURPHY, R.W.; SITES, J.W.Jr.; BUTH, D.G.; HAUFLER, C.H. Preteins I: isozyme electrophoresis. In: HILLIS, D.M.; MORITZ, C. (Ed.) Molecular Systematics. Sunderland: Sinauer Associates, 1990. p.45-126.

OT'T, J. Analysis of human genetic linkage. Baltimore: Johns Hopkins University Press, 1991. 382p.

PACCOLA-MEIRELLES, L.D.; FERREIRA, A.S.; MEIRELLES, W.F.; MARRIEL, I.E.; CASELA, C.R. Detection of a bacterium associated with a leaf spot disease of maize in Brazil. Journal Phytopathology, 149, p. 275-279, 2001.

PACCOLA-MEIRELLES, L.D.; MEIRELLES, W.F.; PARENTONI, S.N.; MARRIEL, I.E.; FERREIRA, A.S; CASELA, C.R. Reaction of maize inbred lines to the bacterium Pantoea ananas isolated from Phaeosphaeria leaf spot lesions. Crop Breeding and Applied Biotechnology, v.2, n.4, p.587-590, 2002.

PARLEVLIET, J.E. Components of resistence that reduce the rate of epidemic development. Annual Review of Phytopathology, v.17, p.203-222, 1979.

PASCOE, L.; MORTON, N.E. The use of map functions in multipoint mapping. American Journal Human Genetics, v.40, p.174-183, 1987.

PATERNIANI, M.E.A.G.Z.; SAWAZAKI, E.; DUDIENAS, C.; DUARTE, A.P.; GALLO, P.B. Diallel crosses among maize lines with emphasis on resistance to foliar diseases. Genetics and Molecular Biology, v.23, n.2, p.381-385, 2000.

PATERSON, A.H.; DAMON, S.; HEWITT, J.D.; ZAMIR, D.; RABINOWITCH, H.D.; LINCOLN, S.E.; LANDER, E.S.; TANKSLEY, S.D. Mendelin factors underlying quantitative traits in tomato: comparison across species, generations, and environments. Genetics, v.127, p. 181-197, 1991. 
PEGORARO, D.G.; BARBOSA NETO, J.F.; SOGLIO, F.K.D.; VACARO, E.; NUSS, C.N.; CONCEIÇÃO, L.D.H. Herança da resistência à mancha-foliar de feosféria em milho. Pesquisa Agropecuária Brasileira, Brasília, v.37, n.3, p.329-336, 2002.

PEGORARO, D.G.; BARBOSA NETO, J.F; VACARO, E.; NUSS, C.N.; SOGLIO, F.K.D Efeito de época de semeadura e adubação na mancha-foliar de Phaeosphaeria em milho. Pesquisa Agropecuária Brasileira, Brasília, v.36, n.8, p.1037-1042, 2001.

PEGORARO, D.G.; VACARO, E.; NUSS, C.N.; SOGLIO, F.K.; SERENO, M.J.C.M., BARBOSA NETO, J.F. Incidência da mancha foliar causada pelo fungo Phaeosphaeria maydis em milho: efeito de épocas de semeadura e doses de nitrogênio. In: CONGRESSO NACIONAL DE MILHO E SORGO, 22., Londrina, 1998. Anais. Londrina: ABMS, 1998. p.122.

PEREIRA, O.A.P. Doenças do milho. In: KIMATI, H.; AMORIM, L ;BERGAMIN FILHO, A.; CAMARGO, L.E.A.; REZENDE, J.A.M. (Ed.) Manual de Fitopatologia. 3.ed. São Paulo: Agronômica Ceres, 1997. v.2, p.538-555.

PEREIRA, O.A.P. Situação atual de doenças da cultura do milho no Brasil e estratégias de controle. In: ENCONTRO SOBRE TEMAS DE GENÉTICA E MELHORAMENTO, 12., Piracicaba, 1995. Resistência genética de plantas à doenças. Anais. Piracicaba: ESALQ/USP - Departamento de genética, 1995. p.25-30.

PINTO, N.F.J. de A. Eficiência de fungicidas no controle de doenças foliares do milho. Summa Phytopatologica, v.23, n.3/4, 1997.

PROVINCE, M.A. Sequencial methods of analysis for genome scans. Advances in Genetics, v.42, p.499-514, 2001.

RAMALHO, M.A.P.; SANTOS, J.B. dos; ZIMMERMANN, M.J. de O. Genética quantitativa em plantas autógamas. Goiânia: UFG, 1993. 271p. 
RANE, M.S.; PAYAK, M.M.; RENFRO, B.L.A. Phaeosphaeria leaf spot of maize. Indian Phytopathology Society Bulletin, v.3, p. 7-10, 1965.

RAO, D.C; MORTON, N.E.; LINDSTEN, J.; HULTEN, M.; YEE, S. A mapping function for man. Human Heredity, v.27, p.99-104, 1977.

RIBAUT, J.M.; HOISINGTON, D.A.; DEUTSCH, J.A.; JIANG, C.; GONZALEZ-deLEON, D. Identification of quantitative trit loci under drought conditions in tropical maize I: Flowering parameters and the anthesis-silking interval. Theoretical and Applied Genetics, v.92, p.905-914, 1996.

RICHARDS, A.J. Plant Breeding Systems. London: Stanley Thornes Pub, 1997. 529p.

ROBINSON, I.P. Aloenzimas na genética de populações de plantas. In: ALFENAS, A.C. (Ed.) Eletroforese de Isoenzimas e Proteínas Afins: fundamentos e aplicações em plantas e microorganismos. Viçosa: UFV, 1998. p.329-380.

SAKIYAMA, N.S. Marcadores moleculares e as hortaliças. Horticultura Brasileira, v.11, n.2, p.204-206, 1993.

SAS INSTITUTE. SAS OnlineDoc®: version 8. Cary, 1999.

SATTERTHWAITE, R.E. An approximate distribution of estimates of variance components. Biometrics, v.2, p.110-114, 1946.

SAWAZAKI, E., DUDIENAS, C., PATERNIANI, M.E.A.G.Z., GALVÃO, J.C.C., CASTRO, J.L., PEREIRA, J. Reação de cultivares de milho à mancha de Phaeosphaeria no estado de São Paulo. Pesquisa Agropecuária Brasileira, v.32, n.6, p.585-589, 1997.

SAX, K. The association of size differences with seed coat pattern and pigmentation in Phaseolus vulgaris. Genetics, v.8, p.552-560, 1923. 
SENIOR, M.L.; CHIN, E.C.L.; LEE, M.; SMITH, J.S.C.; STUBER, C.W. Simple sequence repeat markers developed from maize sequences found in the GenBank database: map construction. Crop Science, v.36, p.1676-1683, 1996.

SIBOV, S.T.; SOUZA JÚNIOR, C.L.; GARCIA, A.A.F.; GARCIA, A.F.; SILVA, A.R.; MANGOLIN, C.A.; BENCHIMOL, L.L.; SOUZA, A.P. Molecular mapping in tropical maize (Zea mays L.) using microsatellite markers. 1. Map construction and localization of loci showing distorted segregation. Hereditas, v. 139, p. 96-106, 2003.

SILVA, H.P. Genética da resistência à Phaeosphaeria maydis em milho. Jaboticabal, 2002. 105p. Tese (Doutorado) - Faculdade de Ciências Agrárias e Veterinárias, Universidade Estadual Paulista "Júlio de Mesquita Filho".

SILVA, H.P. Incidência de doenças fúngicas na "safrinha". In: DUARTE, A.P. (Coord.). IV seminário sobre a cultura do milho "Safrinha". Campinas: IAC/CDV, 2000, p.81-86.

SILVA, H.P.; MORO, J.R. Diallel analysis of maize resistence to Phaeosphaeria maydis. Scientia Agricola, v.61, n.1, p.36-42, 2004.

SOKAL, R.R.; ROHLF, F.J. Biometry: the principles and practice of statistics in biological research. New York: Freeman, 1995. 887p.

SOUTHERN, E.M. Detection of specific sequences among DNA fragments separated by electrophoresis. Journal of Molecular Biology, v.98, p.503-517, 1975.

SOUZA, A.P. Biologia molecular aplicada ao melhoramento. In: NASS, L.L.; VALOIS, A.F.C.C.; MELO, I.S.; VALADARES-INGLIS, M.V. (Eds.). Recursos genéticos e melhoramento de plantas. Rondonópolis: Fundação Matogrosso, 2001. p.939-966. 
SOUZA JÚNIOR, C.L.; SANTOS, M.X.; MAGNAVACA, R.; GAMA, E.E.G. Estimativas de parâmetros genéticos na interpopulação de milho BR-105 x BR-106 e suas implicações no melhoramento. Pesquisa Agropecuária Brasileira, v.28, p.473-479, 1993.

STAM, P. Construction of integrated genetic linkage maps by means of a new computer package: JoinMap. Plant Journal, v.3, p.739-744, 1993.

STEEL, R.G.D.; TORRIE, J.H. Principles and procedures of statistics. New York: McGraw-Hill Book Company, 1980. 633p.

STUBER, C.W.; EDWARDS, M.D.; WENDEL, J.F. Molecular marker-facilites investigations of quantitative trait loci in maize. II. Factors influencing yield and its components traits. Crop Science, v.27, p.639-648, 1987.

STUBER, C. W.; LINCOLN, S. E.; HELENTJARIS, T.; LANDER, E. S. Identification of genetic factors contributing to heterosis in a hybrid from two maize inbred lines using molecular markers. Genetics, v.132, p.823-839, 1992a.

STUBER, C.W.; SISCO, P. Marker- facilitated transfer of QTL alleles between elite inbred lines and responses in hybrids. American Seed Trade Association, p.104-113, 1992b. /Apresentado no 46 th Annual corn and shorghum research Conference. Washington, 1992b/

TANKSLEY, S.D. Mapping polygenes. Annual Review of Genetics, v.27, p.205-233, 1993.

VENCOVSKY, R.; BARRIGA, P. Genética biométrica aplicada ao fitomelhoramento. Ribeirão Preto: Sociedade Brasileira de Genética, 1992. 496 p.

VON PINHO, R.G. Metodologias de avaliação, quantificação de danos e controle genético da resistência do milho à Puccinia polysora e Physopella zeae. Lavras, 1998. 140p. Tese (Doutorado) - Universidade Federal de Lavras. 
WANG, S.; BASTEN, C.J.; ZENG, Z.-B. Windows QTL Cartographer 2.0. Departament of Statistics, North Carolina State University, Raleigh, 2004.

YOUNG, N.D. Constructing a plant genetic linkage map with DNA markers. In: PHILLIPS, R.L.; VASIL, I.K. DNA: based markers in plants. Dordrecht: Kluwer Academic, 1994. p.39-57.

ZENG, Z.-B. Precision mapping of quantitative trait loci. Genetics, v.136, p.1457-1466, 1994.

ZENG, Z.-B.; KAO, C-H; BASTEN, C.J. Estimating the genetic architecture of quantitative traits. Genetical Research, v.74, p.279-289, 1999. 